LUCIANO SILVA COSTA RAMOS

\title{
REGIME JURÍDICO DO CONTROLE DE DESPESAS COM PESSOAL
}

Orientador: Professor Associado Dr. Estevão Horvath

UNIVERSIDADE DE SÃO PAULO

FACULDADE DE DIREITO

São Paulo-SP

2020 


\section{LUCIANO SILVA COSTA RAMOS}

\section{REGIME JURÍDICO DO CONTROLE \\ DE DESPESAS COM PESSOAL}

Tese apresentada à banca examinadora do Programa de PósGraduação em Direito, da Faculdade de Direito da Universidade de São Paulo, como exigência parcial para a obtenção do título de Doutor em Direito, na área de concentração de Direito $E$ sob a orientação do Prof. Associado Dr. Estevão Horvath.

\section{UNIVERSIDADE DE SÃO PAULO}


Costa Ramos, Luciano Silva

Regime Jurídico do controle de despesas com pessoal ; Luciano Silva Costa Ramos ; orientador Estevão Horvath Horvath -- São Paulo, 2020. 270

Tese (Doutorado - Programa de Pós-Graduação em Direito Direito Econômico, Financeiro e Tributário) Faculdade de Direito, Universidade de São Paulo, 2020 .

1. Responsabilidade Fiscal. 2. Despesas públicas. 3. Regime jurídico financeiro. 4. Regime jurídico de controle de despesas com pessoal. 5. Gestão fiscal responsável. I. Horvath, Estevão Horvath, orient. II. Título.| 
AOS ALICERCES

QUE ME DÃO O RUMO:

MÃE EUNICE

("TOCANDO EM FRENTE É O LEMA"),

Avó CANDINHA,

IN MEMORIAN

("JEOVÁ VAI NA FRENTE

E VOCÊ VAI ATRÁS!")

E LARISSA

("POR ONDE FOR,

QUERO SER SEU PAR"). 


\title{
Agradecimento
}

(ANDANÇAS* PAULISTAS)

\author{
À Deus, \\ pelas areias por onde eu vim \\ e o luar para descansar!
}

\author{
À Minha Mãe, \\ me ensinou não fazer tréguas \\ e lendas do caminho!
}

\author{
À Líu, irmã, \\ não me deixou fazer guerra, \\ lembrou a terra \\ onde encerro meu bem-querer!
}

Aos amigos Estevão, Conti, Élida, Fred e Daniel, lições e estímulos a jamais encerrar meu caminhar!

\author{
À Larissa, amada Dory, \\ me acompanha aonde eu for chegar!
}

No passo da estrada, só fiz andar, vocês, o sentido!

Muito obrigado!

Axé!

* Edmundo Souto, Danilo Caymmi e Paulinho Tapajós 


\section{LUCIANO SILVA COSTA RAMOS. REGIME JURÍDICO DO CONTROLE DE DESPESAS COM PESSOAL. JANEIRO DE 2020. DOUTORADO. FACULDADE DE DIREITO, UNIVERSIDADE DE SÃO PAULO. SÃO PAULO, 17 DE JANEIRO DE 2020.}

A presente tese foca na adequada sistematização do regime jurídico de controle de despesas com pessoal, estruturado a partir dos princípios conformadores do regime jurídico financeiro, consubstanciados nos valores jurídicos atinentes à supremacia do interesse público, à indisponibilidade do interesse público pela Administração Pública, à solidariedade fiscal e à responsabilidade fiscal. Delineados os parâmetros de uma gestão fiscal responsável, fortalecem-se os instrumentos necessários ao equilíbrio das contas públicas, com a adequada prevenção de riscos fiscais e legitimidade dos gastos públicos. A ênfase em um sistema dotado de unidade e coerência tem como norte a correção de disfuncionalidades atinentes à aplicação das normas de controle de despesas com pessoal previstas na Lei Complementar $\mathrm{n}^{\circ}$ 101, de 04 de maio de 2000, denominada Lei de Responsabilidade Fiscal (LRF). Notadamente, esquadrinha-se a atuação do controle externo exercido pelos tribunais de contas do Brasil, com especial ênfase nos mecanismos de correção da multiplicidade de interpretações contraditórias dentro do sistema. Para resguardar o regime jurídico de controle de despesas com pessoal, traça-se parâmetros para evitar tentativas artificiais utilizadas por gestores públicos irresponsáveis para evadir as contas públicas por eles geridas das sujeições pertinentes ao regime de direito público. Por fim, esboça-se soluções para a problemática norteadora da tese, construída a partir da experiência no exercício do controle externo, somadas a perspectivas de construções legislativas para corrigir as falhas detectadas no controle de despesas com pessoal, de modo a efetivamente prevenir riscos fiscais e corrigir desvios capazes de acarretar desequilíbrios nas contas públicas.

PALAVRAS CHAVES:

RESPONSABILIDADE FISCAL - REGIME JURÍDICO FINANCEIRO - CONTROLE DE DESPESAS COM PESSOAL — GESTÃO FISCAL RESPONSÁVEL 


\section{LUCIANO SILVA COSTA RAMOS. LEGAL REGIME OF EXPENDITURES WITH PUBLIC WORKERS. JANUARY 2020. DOCTORATE. FACULTY OF LAW, UNIVERSITY OF SAO PAULO. SAO PAULO, JANUARY 17, 2020.}

The present thesis focuses on the adequate systematization of the legal regime of expenditures with public workers control. This legal regime most be structured from the conforming principles of the financial legal regime, embodied in the legal values related to the supremacy of the public interest, the unavailability of the public interest by the Public Administration, fiscal solidarity and fiscal accountability. Outlined the parameters of fiscal accountability management, the necessary instruments to balance public accounts are strengthened, with the appropriate prevention of fiscal risks and legitimacy of public spending. The emphasis on a system endowed with unity and coherence is based on the correction of dysfunctions related to the application of the personnel expenses control rules provided for in Complementary Law $\mathrm{N}^{\circ}$. 101, of May 4, 2000, called Fiscal Responsibility Law (LRF). Notably, the work scans the performance of external control exercised by the Brazilian audit courts, with special emphasis on mechanisms for correcting the multiplicity of contradictory interpretations within the system. In order to safeguard the legal regime of public expenditures control, parameters are set to avoid artificial attempts by irresponsible public managers to evade their public accounts from the relevant subjections of the public law regime. Finally, the thesis outlines solutions to its guiding problem, built on experience in the exercise of external control, added to the prospects of legislative construction to correct the flaws detected in the public expenditures control, in order to effectively prevent fiscal risks and correct deviations that could lead to imbalances in public accounts.

Key words:

FISCAL ACCOUNTABILITY - FINANCIAL LEGAL REGIME — EXPENDITURES WITH PUBLIC WORKERS CONTROL - FINANCIAL MANAGEMENT ACCOUNTABILITY 


\section{RIASSUNTO}

\section{LUCIANO SILVA COSTA RAMOS. SCHEMA GIURIDICO PER IL CONTROLLO DELLE}

SPESE DEL PERSONALE. GENNAIO 2020. DOTTORATO. FACOLTÀ DI GIURISPRUDENZA, UNIVERSITÀ DI SAN PAOLO. SAN PAOLO, 17 GENNAIO 2020.

La presente tesi si concentra sull'adeguata sistematizzazione del regime giuridico del controllo delle spese con funzionari pubblici, strutturato in base ai principi conformi del regime giuridico finanziario, incarnato nei valori legali relativi alla supremazia dell'interesse pubblico, all'indisponibilità dell'interesse pubblico da parte della Pubblica Amministrazione, alla solidarietà fiscale e responsabilità fiscale. Delineati i parametri della gestione fiscale responsabile, vengono rafforzati gli strumenti necessari per bilanciare i conti pubblici, con un'adeguata prevenzione dei rischi fiscali e la legittimità della spesa pubblica. L'enfasi su un sistema dotato di unità e coerenza si basa sulla correzione delle disfunzioni relative all'applicazione delle regole di controllo delle spese con funzionari pubblici previste dalla legge complementare n. 101 del 4 maggio 2000, denominata Fiscal Responsibility Law (LRF). In particolare, viene esaminato il controllo esterno esercitato dai corti dei conti brasiliani, con particolare attenzione ai meccanismi per correggere la molteplicità di interpretazioni contraddittorie all'interno del sistema. Al fine di salvaguardare il regime legale di controllo delle spese con funzionari pubblici, vengono stabiliti parametri per evitare tentativi artificiali da parte di manager pubblici irresponsabili di eludere i loro conti pubblici dalle pertinenti sottomissioni al regime di diritto pubblico. Infine, pongono soluzioni al problema guida della tesi, basate sull'esperienza nell'esercizio del controllo esterno, aggiunte alle prospettive di costruzione legislativa per correggere i difetti rilevati nel controllo delle spese del personale, al fine di prevenire efficacemente i rischi fiscali e correggere le deviazioni che potrebbero portare a squilibri nei conti pubblici.

\section{PAROLE CHIAVE:}

RESPONSABILITÀ FISCALE - REGIME GIURIDICO FINAZIARIO - CONTROLLO DELLE SPESE CON FUNZIONARI PUBBLICI — GESTIONE FISCALE RESPONSABILE 


\section{SUMÁRIO}

CAPÍTULO I - PREMISSAS

1. INTRODUÇÃO

1.1 EQUILÍBRIO ENTRE MEIOS E FINS DO ESTADO

1.2 CONTEXTO HISTÓRICO E ECONÔMICO DAS FINANÇAS PÚBLICAS NO FINAL DA SEGUNDA DÉCADA DO SÉCULOXXI

1.3 O PAPEL DESEMPENHADO PELOS TRIBUNAIS DE CONTAS ESTADUAIS E MUNICIPAIS NESSE CONTEXTO ECONÔMICO

1.5 DAS FALHAS SISTÊMICAS DO REGIME DE CONTROLE DE DESPESAS COM PESSOAL

1.6 DA SUSTENTABILIDADE DO ESTADO FISCAL NO SÉCULO XXI

CAPÍTULO II - PROBLEMÁTICA

2. DA PROBLEMÁTICA A SER TRABALHADA

2.1 INDAGAÇÕES CONCEITUAIS DO DIREITO FINANCEIRO $\quad 74$

2.2 INDAGAÇÕES QUANTO À SUSTENTABILIDADE FISCAL

2.3 INDAGAÇÕES ESPECÍFICAS QUANTO AOS LIMITES DA LEI DE RESPONSABILIDADE FISCAL 76

2.4 INDAGAÇÕES QUANTO À ATUAÇÃO DOS TRIBUNAIS DE CONTAS 77

CAPÍTULO III - DEFINIÇÕES CENTRAIS

3. PILARES CONCEITUAIS

3.1 CONCEITO JURÍDICO DE DESPESAS PÚBLICAS

3.1.1 DESPESAS OBRIGATÓRIAS DE CARÁTER CONTINUADO

3.1.2 DESPESAS COM PESSOAL 88

3.2 DISCRICIONARIEDADE E DESPESA PÚBLICA

3.2.1 DA DESPESA PÚBLICA COMO ATIVIDADE ADMINISTRATIVA 91

3.2.2 DA LIBERDADE NO ÂMBITO PRIVADO 93

3.2.3 DA DELIMITAÇÃO DA DISCRICIONARIEDADE ADMINISTRATIVA EM COTEJO COM A REALIZAÇÃO

3.2.3.1 DA AUTONOMIA PÚBLICA EM COTEJO COM A FINALIDADE DE INTERESSE PÚBLICO E A ESCOLHA ÓTIMA DO ADMINISTRADOR PÚBLICO 98

3.2.3.2 DA DICOTOMIA ENTRE A DISCRICIONARIEDADE LEGÍTIMA E A ARBITRARIEDADE PROIBIDA

3.3.3.3 DOS PARÂMETROS DE VALIDADE DAS ESCOLHAS A CARGO DO AGENTE PÚBLICO 102

$\begin{array}{ll}\text { 3.3 DA FUNÇÃO ADMINISTRATIVA DE CONTROLE } & 105\end{array}$

3.4 DA FUNÇÃO DAS NORMAS GERAIS COMO HARMONIZADORAS DO SISTEMA

CAPÍTULO IV - REGIME JURÍDICO FINANCEIRO

4. ELEMENTOS DO REGIME JURÍDICO FINANCEIRO

4.1 DA RELEVÂNCIA DA DEFINIÇÃO DO REGIME JURÍDICO FINANCEIRO 112

4.2 REGIME JURÍDICO FINANCEIRO X REGIME JURÍDICO ADMINISTRATIVO 123

4.3 PRINCÍPIOS ESTRUTURANTES DO REGIME JURÍDICO FINANCEIRO

4.3.1 PRINCÍPIO DA SUPREMACIA DO INTERESSE PÚBLICO SOBRE O INTERESSE PRIVADO 126

4.3.2 PRINCÍPIO DA INDISPONIBILIDADE DO INTERESSE PÚBLICO PELA ADMINISTRAÇÃO PÚBLICA 131 
4.3.3 PRINCÍPIO DA SOLIDARIEDADE FISCAL 134

4.3.4 PRINCÍPIO DA RESPONSABILIDADE FISCAL 138

CAPÍTULO V - REGIME JURÍDICO DO CONTROLE DE DESPESAS COM PESSOAL 142

5. ELEMENTOS DO REGIME JURÍDICO DO CONTROLE DE DESPESAS COM PESSOAL 142

5.1 DA IDENTIFICAÇÃO TOPOLÓGICA DO REGIME JURÍDICO DE CONTROLE DE DESPESAS COM PESSOAL 142

5.2 CONTROLE QUANTITATIVO DA DESPESA COM PESSOAL 149

5.2.1 LIMITES DE DESPESA COM PESSOAL 149

5.2.2 PREVISÃO NA CONSTITUIÇÃO DA REPÚBLICA X PREVISÃO NA LEI DE RESPONSABILIDADE FISCAL

5.2.3 NATUREZA JURÍDICA E FINALIDADES 163

5.2.3.1 DO LIMITE DE ALERTA 167

5.2.3.2 DO LIMITE PRUDENCIAL 172

5.2.3.3 DO LIMITE TOTAL DE DESPESAS COM PESSOAL 174

5.2.3.4 DA REPARTIÇÃO DOS LIMITES DE DESPESA COM PESSOAL ENTRE OS ÓRGÃOS E PODERES

PÚBLICOS

5.3 DOS EFEITOS JURÍDICOS DECORRENTES DA ULTRAPASSAGEM DOS LIMITES DE DESPESA COM

$\begin{array}{lr}\text { PESSOAL } & 180\end{array}$

5.3.1 DAS CONSEQUÊNCIAS EXPLÍCITAS NA LEI DE RESPONSABILIDADE FISCAL 180

5.3.2 DOS DEVERES IMPLÍCITOS DO REGIME JURÍDICO DE CONTROLE DE DESPESAS COM PESSOAL 183

5.4 DO INCIPIENTE CONTROLE QUALITATIVO DE DESPESAS COM PESSOAL

CAPÍTULO VI - CONTROLE EXTERNO DAS DESPESAS COM PESSOAL 190

6. DO CONTROLE DA DESPESA COM PESSOAL EXERCIDO PELOS TRIBUNAIS DE CONTAS 190

6.1 DAS CONTRADIÇÕES DENTRO DO SISTEMA DE CONTROLE EXTERNO 190

6.2 DA COMPETÊNCIA DOS TRIBUNAIS DE CONTAS PARA RESPONDER CONSULTAS 193

6.3 DA NATUREZA DOS DIREITOS DECORRENTES DAS INTERPRETAÇÕES DADAS PELOS TRIBUNAIS DE CONTAS DOS DISPOSITIVOS DE CONTROLE DAS DESPESAS COM PESSOAL DA LEI DE

$\begin{array}{ll}\text { RESPONSABILIDADE FISCAL } & 197\end{array}$

6.4 DAS RAZÕES QUE SUBTRAEM DO PODER JUDICIÁRIO A APRECIAÇÃO DE DETERMINADAS INTERPRETAÇÕES/APLICAÇÕES DA LEI DE RESPONSABILIDADE FISCAL 202

6.5 DA INEFICÁCIA ATUAL DO SISTEMA PARA UNIFICAR INTERPRETAÇÕES DA LRF QUANTO A DESPESAS COM PESSOAL QUE NÃO AFETEM DIRETAMENTE DIREITOS INDIVIDUAIS 205

6.6 DA DIVERSIDADE DE ESTRUTURAS ENTRE O SISTEMA COMPOSTO PELOS TRIBUNAIS DE CONTAS E O PODER JUDICIÁRIO BRASILEIRO 212

6.7 CONCLUSÃO DO CAPÍTULO 213

CAPÍTULO VII - DA POTENCIAL FUGA DAS SUJEIÇÕES DO REGIME DE CONTROLE DE DESPESAS COM PESSOAL

7. DAS ROTAS DE FUGA DOS CONTROLES DE DESPESA COM PESSOAL 215

7.1 DOS LIMITES DE ESCOLHA DO REGIME JURÍDICO INCIDENTE SOBRE A ATIVIDADE ADMINISTRATIVA $\quad 217$

7.2 DO PODER CONSTITUINTE ORIGINÁRIO E O REGIME JURÍDICO PRÓPRIO DA ATIVIDADE ADMINISTRATIVA 
7.3 DOS LIMITES DE ALTERAÇÃO DAS ESCOLHAS CONSTITUCIONAIS 234

7.4 DA OPÇÃO FEITA PELO LEGISLADOR INFRACONSTITUCIONAL 235

7.5 DA OPÇÃO FEITA PELA ADMINISTRAÇÃO PÚBLICA 239

7.6 DA TERCEIRIZAÇÃO COMO POTENCIAL FUGA DO REGIME JURÍDICO DE CONTROLE DA DESPESA COM PESSOAL $\quad 242$

$\begin{array}{ll}7.7 \text { CONCLUSÃO DO CAPÍTULO } & 248\end{array}$

CAPÍTULO VIII - CONCLUSÃO

8. SÍNTESE CONCLUSIVA 250

8.1 INDAGAÇÕES CONCEITUAIS DO DIREITO FINANCEIRO 251

8.2 INDAGAÇÕES QUANTO À SUSTENTABILIDADE FISCAL 252

8.3 INDAGAÇÕES ESPECÍFICAS QUANTO AOS LIMITES DA LEI DE RESPONSABILIDADE FISCAL 253

8.4 INDAGAÇÕES QUANTO À ATUAÇÃO DOS TRIBUNAIS DE CONTAS 254

9. BIBLIOGRAFIA 256 


\section{CAPÍTULO I \\ PREMISSAS}

\section{INTRODUÇÃO}

Em linhas gerais, a ordem jurídica estabelecida pela Constituição da República de 1988 representou avanços em relação à disciplina normativa das finanças públicas até então existente, notadamente no que tange ao planejamento fiscal, à legitimidade e eficácia do orçamento, à responsabilidade fiscal e à sustentabilidade financeira.

De fato, intensificou-se a ênfase no controle de determinadas despesas, calcada no equilíbrio dessas com as receitas aptas a lhes fazer frente, notadamente no que tange aos gastos cuja magnitude e constância ensejam potencial risco à sustentabilidade financeira das contas públicas, acaso não sejam adequadamente disciplinados, como é o caso das despesas com pessoal.

Com efeito, em consonância com a doutrina de Ricardo Lobo Torres ${ }^{1}$, a Constituição de 1988 instituiu efetivo "Estado Democrático e Social Fiscal”, com preocupações financeiras e sociais inerentes a um "Estado Aberto que instrumentaliza a liberdade e a concorrência na época da sociedade cosmopolita de mercado" (TORRES, 2018, p. 546).

Somado a esse basilar ponto de partida, imperioso reconhecer o ponto nodal da responsabilidade fiscal representado pela Lei Complementar $\mathrm{n}^{\circ} 101$, de 05 de maio de 2000 doravante denominada Lei de Responsabilidade Fiscal (LRF), a qual conecta-se ao ciclo de legitimação da gestão fiscal que lhe antecedeu, enfatizando o equilíbrio das contas públicas e a responsividade fiscal (MOREIRA NETO, 2001, p.86) ${ }^{2}$.

À evidência, ao voltar os olhos para o contexto no qual se deu a promulgação da Lei de Responsabilidade Fiscal, observa-se o quanto era imperioso alcançar a estabilidade fiscal, o que inexoravelmente requeria uma inflexão na gestão fiscal, de modo a transformar o quadro caótico então vivido quanto ao dispêndio de recursos públicos em um sistema ordenado por planejamento, controle de despesas e equilíbrio de receitas e despesas.

Assim, para uma adequada compreensão do contexto no qual emergiu esse novo

\footnotetext{
${ }^{1}$ TORRES, Ricardo Lobo. Tratado de direito constitucional financeiro e tributário, Vol. I - Constituição financeira, sistema tributário e estado fiscal.. - Rio de Janeiro : Renovar, 2009.

${ }^{2}$ MOREIRA NETO, Diogo de Figueiredo. Considerações sobre a Lei de Responsabilidade Fiscal. Rio de Janeiro: Renovar, 2001.
} 
diploma normativo disciplinador da responsabilidade fiscal e as disfuncionalidades que tornaram imprescindível a sua promulgação, tome-se a cirúrgica descrição procedida por Carlos Maurício Figueiredo e Marcos Nóbrega ${ }^{3}$ :

Para entendermos as razões da necessidade da implantação de uma lei tão
inovadora como a LRF, precisamos analisar as origens próximas da crise fiscal
brasileira. No período pós-estabilização houve uma aguda crise financeira nos
Estados, tanto que, no período entre 1995 e 1998 , os Estados e Municípios
apresentaram deficits primários em média de $0,4 \%$ do PIB, ao passo que o
Governo central apresentava superavits de cerca de $0,3 \%$ do PIB
(FIGUEIREDO, et al., 2006, pp. 67/68).

Dessarte, era imperioso traçar o regime jurídico que impusesse uma responsabilidade fiscal substantiva, e não meramente formal, com a busca da legitimidade na gestão fiscal, pois o cenário que antecedeu a Lei de Responsabilidade Fiscal era tal que "reinava uma quase total irresponsabilidade substantiva na gestão de dinheiros públicos, e por mais desviada, imprudente e arriscada que fosse, os atos quase sempre restavam impunes" (MOREIRA NETO, 2001, p. 52). ${ }^{4}$

Com efeito, a trajetória da gestão fiscal, nada obstante os instrumentos tentados ao longo da década de 90, era tal que requeria um ponto de inflexão, uma mudança em direção a uma maior racionalidade nos gastos públicos, de modo a que não houvesse a proliferação de arbritariedades na condução das finanças públicas, como até então era lugar comum.

À altura da elaboração da Lei de Responsabilidade Fiscal, essas exigências tornaram premente a sua promulgação, inclusive no que tange aos anseios de concretização de uma democracia material, tal qual delineado por Diogo de Figueiredo Moreira Neto ${ }^{5}$ :

Por isso é que a caracterização jurídica de uma responsabilidade fiscal
substantiva, que abrisse condições de superar o simples aspecto formal, da mera
legalidade, e de dar uma satisfação aos justos reclamos de legitimidade da gestão
fiscal, tornou-se um tema juspolítico fundamental dentro de uma justíssima
ambição, de maior envergadura, de implantação de uma real democracia
material, com a esperança e a inspiração alimentadas nas experiências recentes
de outros países, que, de algum modo, já lograram auspiciosos progressos no
difícil caminho do aperfeiçoamento da gestão fiscal democrática (MOREIRA
NETO, 2001, pp. 52/53).

Outrossim, a crise fiscal da década de 90 supra referida, tal qual as que de tempos em tempos vivencia-se no país, inclusive a atual, esteve diretamente ligada ao inadequado

${ }^{3}$ FIGUEIREDO, Carlos Maurício; NÓBREGA, Marcos. Lei de Responsabilidade Fiscal: aspectos polêmicos. Belo Horizonte: Fórum, 2006.

${ }^{4}$ MOREIRA NETO, Diogo de Figueiredo. Considerações sobre a Lei de Responsabilidade Fiscal. Rio de Janeiro: Renovar, 2001.

${ }^{5}$ Ob. cit. 
controle de despesas com pessoal até então utilizado, consoante prosseguem Carlos Maurício Figueiredo e Marcos Nóbrega ${ }^{6}$ :

Essa piora fiscal dos Estados se deveu basicamente a dois fatores:

a) aumentos significativos com gastos com o funcionalismo público, caracterizado pela concessão indiscriminada de reajustes salariais;

b) peso crescente dos gastos com inativos nas folhas de pagamento, alavancado pelas regras 'perversas' da aposentadoria por tempo de serviço e as aposentadorias especiais (FIGUEIREDO, et al., 2006, p. 68).

Com essas balizas e necessidades prementes, notadamente quanto à contenção das despesas com pessoal, observa-se que a previsão normativa foi adequadamente elaborada e alcançou inicialmente a missão a que se propunha. Mas, notadamente ao longo da última década, a responsabilidade fiscal sofreu retrocessos no Brasil, com a gradativa mitigação das medidas pensadas para conter os gargalos para o almejado equilíbrio fiscal.

Ainda assim, é inquestionável o avanço representado pela Lei de Responsabilidade Fiscal, que não se limitou a disciplinar os arts. 163 e 169 da Constituição da República de 1988, mas, sim, delineou um sistema de responsabilidade fiscal em linha com os valores constitucionais.

Dessarte, a Constituição da República deu os contornos normativos dentro dos quais a lei complementar de finanças públicas haveria de desenhar o regime jurídico da responsabilidade fiscal, norteado pela conjunção destes dois dispositivos, partindo do mais amplo art. 163:

Art. 163. Lei complementar disporá sobre:

I - finanças públicas;

II - dívida pública externa e interna, incluída a das autarquias, fundações e demais entidades controladas pelo Poder Público;

III - concessão de garantias pelas entidades públicas;

IV - emissão e resgate de títulos da dívida pública;

V - fiscalização financeira da administração pública direta e indireta; (Redação dada pela Emenda Constitucional n ${ }^{\circ} 40$, de 2003)

VI - operações de câmbio realizadas por órgãos e entidades da União, dos Estados, do Distrito Federal e dos Municípios;

VII - compatibilização das funções das instituições oficiais de crédito da União, resguardadas as características e condições operacionais plenas das voltadas ao desenvolvimento regional.

\footnotetext{
${ }^{6}$ FIGUEIREDO, Carlos Maurício; NÓBREGA, Marcos. Lei de Responsabilidade Fiscal: aspectos polêmicos.
} Belo Horizonte: Fórum, 2006. 
Nesses termos, força há em convir que o controle das despesas com pessoal, inclusive no que tange ao estabelecimento de limites e demais dispositivos necessários para a concretização da responsabilidade fiscal, está abrangido pela previsão constitucional de disciplina em norma geral quanto a finanças públicas (CR/88, art. 163, inciso I) e fiscalização financeira da administração pública direta e indireta (CR/88, art. 163, inciso V).

E a partir destas fronteiras, conjugando sistematicamente estes dois dispositivos constitucionais, a referida lei complementar haveria de delinear o específico regime jurídico de despesas com pessoal, em consonância com o art. 169 da Constituição da República:

Art. 169. A despesa com pessoal ativo e inativo da União, dos Estados, do Distrito Federal e dos Municípios não poderá exceder os limites estabelecidos em lei complementar.

$\S 1^{\circ}$ A concessão de qualquer vantagem ou aumento de remuneração, a criação de cargos, empregos e funções ou alteração de estrutura de carreiras, bem como a admissão ou contratação de pessoal, a qualquer título, pelos órgãos e entidades da administração direta ou indireta, inclusive fundações instituídas e mantidas pelo poder público, só poderão ser feitas:

I - se houver prévia dotação orçamentária suficiente para atender às projeções de despesa de pessoal e aos acréscimos dela decorrentes;

II - se houver autorização específica na lei de diretrizes orçamentárias, ressalvadas as empresas públicas e as sociedades de economia mista.

$\S 2^{\circ}$ Decorrido o prazo estabelecido na lei complementar referida neste artigo para a adaptação aos parâmetros ali previstos, serão imediatamente suspensos todos os repasses de verbas federais ou estaduais aos Estados, ao Distrito Federal e aos Municípios que não observarem os referidos limites.

$\S 3^{\circ}$ Para o cumprimento dos limites estabelecidos com base neste artigo, durante o prazo fixado na lei complementar referida no caput, a União, os Estados, o Distrito Federal e os Municípios adotarão as seguintes providências:

I - redução em pelo menos vinte por cento das despesas com cargos em comissão e funções de confiança;

II - exoneração dos servidores não estáveis.

$\S 4^{\circ} \mathrm{Se}$ as medidas adotadas com base no parágrafo anterior não forem suficientes para assegurar o cumprimento da determinação da lei complementar referida neste artigo, o servidor estável poderá perder o cargo, desde que ato normativo motivado de cada um dos Poderes especifique a atividade funcional, o órgão ou unidade administrativa objeto da redução de pessoal.

$\S 5^{\circ} \mathrm{O}$ servidor que perder o cargo na forma do parágrafo anterior fará jus a indenização correspondente a um mês de remuneração por ano de serviço.

$\S 6^{\circ} \mathrm{O}$ cargo objeto da redução prevista nos parágrafos anteriores será considerado extinto, vedada a criação de cargo, emprego ou função com atribuições iguais ou assemelhadas pelo prazo de quatro anos.

$\S 7^{\circ}$ Lei federal disporá sobre as normas gerais a serem obedecidas na efetivação do disposto no $\S 4^{\circ}$.

Evidentemente, uma vez traçado o arcabouço constitucional, com seu inexorável nível 
de abstração mais amplo, a remissão a uma lei complementar redunda na imperiosidade desta se aprofundar dentro dos contornos de validade constitucionalmente estabelecidos, de modo a caminhar em direção à concretização do valor responsabilidade fiscal, pilar do direito financeiro.

Em assim sendo, o adequado entendimento do sistema de responsabilidade fiscal, abrangendo suas implicações para o controle de gastos com pessoal, há de ser balizado pela harmonização desses dois dispositivos constitucionais (arts. 163 e 169 da Constituição da República), de modo a capturar toda a sua amplitude.

Nesses termos, pronunciaram-se Carlos Maurício Figueiredo e Marcos Nóbrega ${ }^{7}$ :

(...) a LRF, no que se refere aos gastos com pessoal, não se restringe a regular o artigo 169 da Constituição Federal, como muitos acreditam. Na verdade, a lei de gestão fiscal é bem mais ampla, dando, portanto, cumprimento ao comando constitucional que determina a veiculação de lei de espécie complementar para regular os comandos do artigo 163 . Tanto é assim, que o art. $1^{\circ}$ da LRF dispõe: 'Art. $1^{\circ}$ Esta Lei Complementar estabelece normas de finanças públicas voltadas para a responsabilidade na gestão fiscal, com amparo no Capítulo II do Título VI da Constituição. Percebe-se que a LRF trata sobre finanças públicas, em seus diversos aspectos (FIGUEIREDO, et al., 2006, p. 206).

Com o propósito de convergir para esse desiderato constitucional, a LRF significou inegável avanço dos instrumentos até então disponíveis para o equilíbrio das finanças públicas, em efetiva evolução do quadro normativo existente na década de 1990, exemplificado no caso do controle das despesas com pessoal pela Lei Complementar $n^{\circ}$ 82/95 (denominada Lei Camata I) e Lei Complementar nº 96/99 (denominada Lei Camata II).

$\mathrm{O}$ avanço mencionado pretendia alcançar êxito em situações em que essas e outras normas não foram capazes, além de ajustar o país à nova realidade das finanças públicas, posterior à estabilidade da moeda, duramente alcançada em meados da década de 1990, mas que requereu ajustes em face dos desequilíbrios fiscais camuflados pela hiperinflação.

Em assim sendo, força há em convir que a Lei de Responsabilidade Fiscal consubstancia singular "marco regulatório fiscal brasileiro", consoante delineado por Marcus Abraham $^{8}$ :

Não apenas para dar efetividade à política de estabilização fiscal que se implementava em fins da década de 1990 e início de 2000, e para regulamentar dispositivos da Constituição Federal de 1988 que demandavam uma lei complementar sobre matérias financeiras, a promulgação da LRF foi instituída

\footnotetext{
${ }^{7}$ FIGUEIREDO, Carlos Maurício; NÓBREGA, Marcos. Lei de Responsabilidade Fiscal: aspectos polêmicos. Belo Horizonte: Fórum, 2006.

8 ABRAHAM, Marcus. Reflexões sobre finanças públicas e direito financeiro. Salvador: Editora JusPodivm, 2019.
} 
para apresentar um novo marco regulatório fiscal no Brasil, baseado no planejamento, na transparência, no controle e equilíbrio das contas públicas e na imposição de limites para determinados gastos e para o endividamento (ABRAHAM, 2019 p. 70).

Mas, conquanto reconheça-se a importância desse marco regulatório fiscal, não se pode olvidar que os quase 20 anos de sua vigência não foram capazes de afastar as constantes crises de sustentabilidade financeira da realidade das finanças públicas no Brasil, o que impõe a inexorável necessidade de aprofundar as causas desse quadro indesejado, bem como buscar soluções para esses eternos desequilíbrios.

Nessa linha, observa-se que ainda há incontáveis avanços a serem feitos, em especial no que concerne à concretização dos valores constitucionais em uma adequada governança fiscal, o que passa por ajustes na legislação infraconstitucional - com ênfase nas normas gerais de Direito Financeiro e sua aplicação pela Administração Pública -, bem como no controle procedido sobre a gestão pública e na sistematização da exegese dos seus dispositivos.

Dessarte, sem desconsiderar o marco fiscal representado pela Lei Complementar $\mathrm{n}^{\mathrm{o}}$ 101/00, mas ainda assim enxergando a necessidade da continuidade dos avanços que remontam à década de 1980, converge o pensamento para as lições de Cristiane Kerches da Silva Leite ${ }^{9}$ :

\begin{abstract}
A Lei de Responsabilidade Fiscal foi um marco não somente no processo de ordenamento fiscal e financeiro, mas também nas relações políticas federativas. A despeito da sua importância, a LRF não pode ser considerada uma lei que garante o ordenamento permanente da administração pública. Esta lei faz parte de um processo inacabado de aperfeiçoamento da gestão fiscal que começou na década de 1980 e teve como ponto de inflexão analiticamente relevante o impacto do Plano Real nas finanças públicas dos entes federativos. É preciso avançar no campo orçamentário e das finanças públicas, de um modo geral, corrigindo algumas falhas de normatização (LEITE, 2011 p. 26).
\end{abstract}

E assim o é, pois, nada obstante a Lei de Responsabilidade Fiscal (LRF) ter efetivamente configurado um marco para o Direito Financeiro e consubstanciado uma guinada nas finanças públicas brasileiras em direção à efetiva responsabilidade fiscal - em linha com os pensamentos de Marcus Abraham e Cristiane Leite supracitados -, ainda assim, é patente o fato de que o sistema jurídico por ela desenhado permanece incompleto e, em muitos aspectos, disfuncional, a ponto de ser incapaz de coibir inúmeras irresponsabilidades na

\footnotetext{
${ }^{9}$ LEITE, Cristiane Kerches da Silva. TD 1593 - Federalismo, processo decisório e ordenamento fiscal: a criação da Lei de Responsabilidade Fiscal. Instituto de Pesquisa Econômica Aplicada - IPEA. [Online] Março de 2011. http://www.ipea.gov.br/portal/images/stories/PDFs/TDs/td_1593.pdf.
} 
gestão dos recursos públicos.

Assim não tivesse sido, não mais estaríamos diante de "despesas desprovidas de qualidade e legitimidade, desequilíbrio entre receitas e despesas públicas, geração de deficits impagáveis, ciclo orçamentário irreal, desconexo e desprovido de efetividade" (ABRAHAM, 2019 , p. 70) ${ }^{10}$, haja vista todas elas serem incompatíveis com a essência da responsabilidade fiscal e haver normas previstas na Lei de Responsabilidade Fiscal para coibir cada uma dessas situações.

Destacadamente, ao longo da vigência da Lei de Responsabilidade Fiscal (LRF) algumas medidas por ela pensadas não foram capazes de concretizar o equilíbrio físcal pretendido no ordenamento jurídico, sobretudo no que tange à aplicação de limites para os gastos públicos em geral, com especial ênfase nas despesas obrigatórias de caráter continuado cristalizadas na rubrica de pessoal, consoante requerido pelo citado art. 169 da Constituição da República (CR/88).

Nada obstante a importância da LRF, evidentemente, o arcabouço da responsabilidade fiscal não encerrou seu ciclo com o advento desta lei complementar, requerendo ainda uma série de avanços para atingir sua completude, no campo institucional inclusive.

Igualmente, esse fato foi observado por Cristiane Leite ${ }^{11}$ :

Há uma série de mudanças que ainda precisam ser feitas para completar a "agenda da responsabilidade fiscal". É preciso que um conjunto de instituições funcione de forma coordenada para elevar a responsabilidade fiscal dos gestores públicos (KHAIR; AFONSO; OLIVEIRA, 2006). Por exemplo, punições "financeiro-administrativas" que podem afetar especificamente os entes federativos são aplicadas especificamente pela STN: a maioria das transferências voluntárias é feita da União para estados e municípios, operacionalizadas pelo Cadastro Único de Transferências Voluntárias, sendo responsabilidade da STN o controle dessas transferências e a análise dos pleitos de autorização para a contratação de operações de crédito pela União, pelos estados, municípios e seus órgãos (LEITE, 2011 p. 26).

Vale dizer, o quanto pensado em abstrato na Lei de Responsabilidade Fiscal não se traduziu na prática naquilo que se pretendia desde a elaboração da norma, como se pode observar na doutrina contemporânea à sua promulgação.

Cite-se, exemplificativamente, as palavras de Márcio Novaes Cavalcanti ${ }^{12}$ :

\footnotetext{
${ }^{10}$ ABRAHAM, Marcus. Reflexões sobre finanças públicas e direito financeiro. Salvador: Editora JusPodivm, 2019.

${ }^{11}$ LEITE, Cristiane Kerches da Silva. TD 1593 - Federalismo, processo decisório e ordenamento fiscal: a criação da Lei de Responsabilidade Fiscal. Instituto de Pesquisa Econômica Aplicada - IPEA. [Online] Março de 2011. http://www.ipea.gov.br/portal/images/stories/PDFs/TDs/td_1593.pdf.

${ }^{12}$ CAVALCANTI, Márcio Novaes. Fundamentos da Lei de Responsabilidade Fiscal. São Paulo: Dialética, 2001.
} 
A Lei de Responsabilidade Fiscal não pune somente o administrador irresponsável, mas também aquele que deixa de dar transparência à sua gestão. Não só sanciona, mas avisa antecipadamente que vai punir. $\mathrm{O}$ monitoramento acontece bem de perto. A arrecadação tem de ser feita, os limites de gastos têm de ser respeitados e os limites com pessoal são sérios. Além disso, dívidas não podem exceder limites, e gastos ao final do governo são impedidos. Não bastasse isso, relatórios devem ser apresentados e dentro de prazos severos. Caso as regras não sejam respeitadas, o governante fica impossibilitado de se socorrer de transferências voluntárias ou contratação de dívidas. Fica sufocado e é obrigado a corrigir a rota. Mais do que isso, é avisado antecipadamente das consequências de sua irresponsabilidade. Em palavras simples, a margem de manobra para faltosos é limitadíssima. Tem de existir uma correção de rumo (CAVALCANTI, 2001 p. 78).

Ocorre que a observação da realidade concreta da aplicação da Lei de Responsabilidade Fiscal contrapõe-se ao prognóstico de "limitação à margem de manobra para faltosos", bem como à inexorabilidade dessa correção de rumo, conforme demonstrado ao longo desta tese.

Em perspectiva, seguiu Márcio Cavalcanti ${ }^{13}$ saudando uma nova era na responsabilidade fiscal, da qual não poderiam fugir os gestores públicos brasileiros:

A sagacidade do administrador irresponsável é desafiada ao limite. Ou cumpre os preceitos da lei e administra dentro de sua arrecadação, ou passa a sofrer limitações. A publicidade, a divulgação por meios eletrônicos dos relatórios que apontam eventual irresponsabilidade, expõe os governantes faltosos ao ridículo e deixa transparente, não só para os fiscalizadores, mas também para os investidores do setor privado ou instituições financeiras, que aquele ente da Federação não é alvo ideal para investimentos. São sanções pesadas. O governante irresponsável fica exposto, inclusive, à censura por parte de seus próprios eleitores e fica com uma margem de manobra bastante restrita (CAVALCANTI, 2001, p. 78).

Embora a descrição abstrata do quadro normativo que se seguiu à LRF esteja correta, as nobres pretensões emperraram em uma engrenagem que impediu a concretização de parte significativa da lei.

Assim, nada obstante o marco que significou a edição da Lei de Responsabilidade Fiscal no Brasil - efetivamente consubstanciada em um divisor de águas -, ela não foi capaz de concretizar em sua integralidade os propósitos justificadores de sua criação.

De fato, o quadro fiscal vivido quando da elaboração, da discussão e da promulgação da Lei de Responsabilidade Fiscal em muitos aspectos se assemelha ao caos fiscal presenciado ao longo dos últimos anos nas contas públicas das três esferas da Federação.

Dessarte, hão de ser buscadas as razões impeditivas para a efetiva consolidação da

${ }^{13}$ Ob. cit. 
cultura de responsabilidade fiscal no país, de modo a afastar o ressurgimento cíclico dos problemas fiscais que o Brasil retornou a viver em anos recentes.

E no que tange ao controle de despesas com pessoal especificamente, tem-se repetidas tentativas normativas de limitá-las, sem que se consiga uma solução que enderece o problema de modo permanente.

Dada a relevância desse tipo de gasto no conjunto das despesas do Estado, bem como a persistente tendência de que ele fuja do controle, a tentativa de limitação das despesas com pessoal não foi inaugurada com a Lei de Responsabilidade Fiscal, nem tampouco com a Constituição da República de 1988.

Ao revés, ela remonta a ordens jurídicas instituídas sob a égide de constituições anteriores a 1988, conforme descrito por Francis Waleska Esteves da Silva ${ }^{14}$ :

\begin{abstract}
A questão da limitação com despesas de pessoal não constitui uma novidade introduzida com a Lei de Responsabilidade Fiscal, tendo sido tema da Constituição de 1967 que previa o limite de cinqüenta por cento aplicável às despesas com pessoal, para as respectivas receitas correntes dos estados federados (art. 66, $\S 4^{\circ}$ ), bem como foi tratada pela Emenda Constitucional $\mathrm{n}^{\circ}$ $1 / 69$ ao estabelecer que lei complementar disciplinaria limites para as despesas de pessoal das pessoas jurídicas de direito público (art. 64) (DA SILVA, 2003 p. 139).
\end{abstract}

Em assim sendo, faz-se necessário perquirir profundamente os motivos pelos quais o controle de despesas com pessoal persiste em ser um desafio inadequadamente resolvido pelo ordenamento jurídico.

De igual sorte, já sob a ordem jurídica encabeçada pela Constituição da República de 1988, a limitação das despesas com pessoal foi reforçada nos anos de 1995 e 1999 com as denominadas leis Camata I e II, sem novamente alcançar a finalidade a que elas se propunham:

Ademais, a Lei Complementar $\mathrm{n}^{\circ}$ 82/95, conhecida como Lei Camata e a Lei Complementar $n^{\circ}$ 96/99 (Lei Camata II), estipularam limites para despesa total com pessoal, sem, contudo, obter êxito na diminuição desses gastos, em razão da ausência de instrumentos capazes de gerar a diminuição de despesa nesse sentido (DA SILVA, 2003 p. 139/140) ${ }^{15}$.

Conquanto a Lei de Responsabilidade Fiscal tenha acrescido uma série de instrumentos para conter as despesas com pessoal, ainda assim, eles tiveram pouca eficácia na

\footnotetext{
${ }^{14}$ DA SILVA, Francis Waleska Esteves. A Lei de Responsabilidade Fiscal e os seus princípios informadores. Rio de Janeiro: Lumen Juris, 2003.

${ }^{15}$ Ob. cit.
} 
obtenção de um resultado duradouro, consoante a realidade ora vivida nas contas públicas brasileiras.

De fato, consoante delineado por José Nilo de Castro ${ }^{16}$ :

A LRF representa um patrimônio da cidadania e é um capital social do cidadão.

Não obstante o fato de existir a ordenação normativa precitada, percebe-se haver, lamentavelmente, nichos com gastos que desservem o espírito e a própria finalidade da LRF, no que diz respeito, especificamente aos gastos de pessoal, cujo controle se impõe com maior severidade pelos órgãos competentes e pela sociedade (CASTRO, 2009, p. 160).

A rigor, os desafios de contenção das despesas de pessoal então postos sobre a mesa quando da virada do milênio - que teriam na Lei de Responsabilidade Fiscal o eixo central de sua solução - em muito se assemelham aos desafios de equalização das contas públicas vividos nesta década do século XXI - e anunciados para ao menos o início da próxima década - , conforme lê-se na digressão histórica feita por Marcus Abraham ${ }^{17}$ quanto aos momentos que antecederam a entrada em vigor da LRF:

Em setembro de 1997, com a edição da Lei n ${ }^{\circ}$ 9.496, a União ficou autorizada a assumir a dívida pública mobiliária dos Estados e do Distrito Federal, além de outras dívidas autorizadas pelo Senado Federal. Ganhava força, a partir de então, a busca pelo desenvolvimento autossustentável, com o Programa de Reestruturação e de Ajuste Fiscal.

Por sua vez, no ano de 1998, o Governo Federal apresenta seu Programa de Estabilidade Fiscal - PEF, justificando que o Estado brasileiro não poderia mais 'viver além de seus limites, gastando mais do que arrecada' (ABRAHAM, 2018 p. 385).

Tal qual um pêndulo que insiste em retornar a posições passadas, a Federação novamente se vê diante da necessidade de resgatar entes incapazes de honrar as suas despesas, com graves quadros de desequilíbrio fiscal, com o agravante que essa indesejável circunstância atualmente atinge fortemente também a União.

À evidência, muitas das ações de outrora encontram reflexos no espelho do presente: os Programas de Reestruturação, Ajuste Fiscal e Estabilidade Fiscal (1997/1998) dando lugar a Novo Regime Fiscal (Emenda Constitucional no 95, de 15 de dezembro de 2016) inclusive com a reiteração de medidas sancionatórias previstas na Lei de Responsabilidade Fiscal - e Regime de Recuperação Fiscal dos Estados e do Distrito Federal (Lei Complementar $\mathrm{n}^{\mathrm{o}} 159$, de 19 de maio de 2017), sem contar as reformas administrativa e

\footnotetext{
${ }^{16}$ CASTRO, José Nilo de. LRF e controle dos gastos de pessoal. In: Servidor público: estudos em homenagem ao Professor Pedro Paulo de Almeida Dutra. FORTINI Cristiana (Org.). Belo Horizonte: Fórum, 2009.

${ }^{17}$ ABRAHAM, Marcus. Curso de Direito Financeiro Brasileiro, $5^{\mathrm{a}}$ edição. Rio de Janeiro: Forense, 2018.
} 
previdenciária de então e de agora.

Outrossim, tem-se Projeto de Lei de Qualidade Fiscal (Projeto de Lei do Senado ${ }^{o}$ 229, de 2009), já aprovado no Senado Federal e remetido à Câmara dos Deputados, cujo papel a ser desempenhado neste momento histórico equivale ao da Lei de Responsabilidade Fiscal quando da sua elaboração.

$\mathrm{Na}$ mesma linha, mas com marcantes aprofundamentos, tem-se a Proposta de Emenda Constitucional $\mathrm{n}^{\circ} 188$ (denominada PEC do Pacto Federativo), recebida pelo plenário do Senado Federal em 05 de novembro de 2019, e atualmente localizada na respectiva Comissão de Constituição, Justiça e Cidadania.

Ou seja, a responsabilidade fiscal no Brasil prossegue uma obra em andamento, a requerer reformas de tempos em tempos para solucionar problemas que já deveriam ter sido sanados com as reformas anteriores.

Com isso, registre-se de antemão, não se está a mitigar a importância dos avanços a serem feitos. Ao revés, afirma-se peremptoriamente a necessidade de ajustes e a edição de novos diplomas normativos.

Mas, não se pode deixar de indagar se a tão só edição de novas normas seria capaz de obter êxito em pontos que a Lei de Responsabilidade Fiscal e outros diplomas até então existentes não foram eficazes. E ainda, se o sistema normativo-institucional ao qual essas novas normas serão incorporadas não seria em si um entrave à concretização da responsabilidade fiscal em sua inteireza?

Questionamentos semelhantes a esses são colocados em questão por José Maurício Conti $^{18}$, na Coluna Fiscal do sítio da internet Jota, em recente artigo:
A falta de efetividade que tem atingido as normas de Direito Financeiro configura um dos mais relevantes problemas a serem enfrentados nessa área, e comprometem toda e qualquer nova alteração, uma vez que está há muito prejudicada a confiabilidade de que normas novas produzirão os efeitos esperados, já que as anteriormente vigentes, e com a mesma finalidade, não atingiram o objetivo.
Melhor seria voltarem-se os esforços para fazer com que sejam cumpridas as normas já existentes, sem o que o ordenamento jurídico perde muito de sua força, e compromete a confiança nas novas normas que surgem para solucionar problemas que não deveriam estar ocorrendo (CONTI, 2019).

Consoante observado ao longo desta pesquisa, o endereçamento do problema do

${ }^{18}$ CONTI, José Maurício. O Plano Mais Brasil e o pacote de mudanças no Direito Financeiro. In: Jota.info. Jota Coluna Fiscal. [Online] 28 de Novembro de 2019.

Disponível em: https://www.jota.info/paywall?redirect to=//www.jota.info/opiniao-e-analise/colunas/colunafiscal/o-plano-mais-brasil-e-o-pacote-de-mudancas-no-direito-financeiro-28112019. Acessado em: 13 de janeiro de 2020 . 
descontrole dessas despesas específicas passa pela reestruturação do regime jurídico de controle de despesa com pessoal, afastando disfuncionalidades sistêmicas, de modo que as pretensões normativas presentes e futuras sejam efetivamente alcançadas.

Ademais, não se está a demonizar a Lei de Responsabilidade Fiscal, pois não lhe cabia o papel de redimir solitária e definitivamente as contas públicas brasileiras, como se fosse a tábua de salvação da responsabilidade fiscal, além de ser um incremento de medidas anteriormente tomadas em direção ao aperfeiçoamento da gestão fiscal.

Comunga-se, destarte, com pensamento de Weder de Oliveira ${ }^{19}$ :

A LRF não deve ser tida como 'A' legislação que irá garantir o equilíbrio fiscal permanente nem como a lei redentora que irá moralizar a administração pública. Ela representa o ponto culminante, até aqui, de um longo processo institucional e legislativo de melhorias paulatinas na gestão fiscal, que começou em meados dos anos 80. E esse processo não se encerrou com a LRF (OLIVEIRA, 2015 p. 49).

À evidência, a responsabilidade fiscal não nasce no ordenamento jurídico brasileiro com o advento da lei, nem tampouco ela se consubstanciou em uma novidade revolucionária em relação às medidas normativas que vinham sendo tentadas ao longo dos anos anteriores para atingir esse desiderato.

Sem sombra de dúvidas, a Lei de Responsabilidade Fiscal dialoga com o contexto no qual ela foi criada, tendo avançado naquilo que lhe foi possível avançar, na esteira do quadro histórico delineado por Cristiane Kerches da Silva Leite ${ }^{20}$ :

Assim, conforme o argumento do incrementalismo, cada medida tomada pelo
governo federal para controlar gastos e endividamento dos estados e municípios,
durante a década de 1990, ajudou a abrir caminho para a aprovação da LRF,
influenciando de alguma forma a trajetória tomada a posteriori, como
demonstram a CPI dos Precatórios e a consequente Resolução do Senado
Federal no 78/1998, assim como o Voto $\mathrm{n}^{\circ} 162 / 2005$ e a Lei $\mathrm{n}^{\circ}$ 9.496/1997.
Além de ter havido um crescente endurecimento nas regras que foram criadas no
decorrer da década, a lei incorporou muitas delas e deu nova organicidade ao
arcabouço legal das finanças federativas (LEITE, 2011, p. 18).

Sendo certo que o "longo processo institucional e legislativo de melhorias paulatinas na gestão fiscal não se encerrou com a LRF" (OLIVEIRA, 2015, p. 49), somado à perspectiva atual de retrocessos nessa caminhada, compete à academia delinear adequadamente esse

\footnotetext{
${ }^{19}$ OLIVEIRA, Weder de. Curso de Responsabilidade Fiscal: direito, orçamento e finanças públicas, $2^{\mathrm{a}}$ edição. Belo Horizonte: Fórum, 2015.

${ }^{20}$ LEITE, Cristiane Kerches da Silva. TD 1593 - Federalismo, processo decisório e ordenamento fiscal: a criação da Lei de Responsabilidade Fiscal. Instituto de Pesquisa Econômica Aplicada - IPEA. [Online] Março de 2011. http://www.ipea.gov.br/portal/images/stories/PDFs/TDs/td_1593.pdf.
} 
quadro e buscar veredas para a retomada segura do caminhar em direção à responsabilidade fiscal.

À evidência, além da necessidade de serem adotadas medidas de ajuste, inclusive no plano da elaboração normativa, é imperioso perquirir o porquê de 20 anos depois o país voltar a flertar com o abismo fiscal que vivia no final do século $\mathrm{XX}$, bem como as razões que levaram às normas postas de responsabilidade fiscal a não cumprir adequadamente a concretização do seu papel de vetores para "instituir uma nova ordem nas contas públicas" (ABRAHAM, 2018, p. 386).

Passados quase vinte anos da promulgação da Lei Complementar $n^{\circ} 101 / 00$ - e mais do que isso do cenário de desajuste fiscal ensejador de sua elaboração -, força há em convir que a responsabilidade fiscal no Brasil não convergiu para a "nova ordem nas contas públicas" prognosticada e almejada na época de sua criação, nada obstante tenha havido êxito nos primeiros anos de sua vigência.

De fato, a lei marca transição da diminuta preocupação com a responsabilidade fiscal em muito camuflada pelo flagelo inflacionário vivido até meados da década de 90 do século passado -, para o enraizamento desse dever jurídico na condução da gestão fiscal. Com isso, alcançou inegáveis resultados positivos nos momentos que sucederam a sua promulgação ${ }^{21}$ :

O caos e a irresponsabilidade fiscal que assolavam nosso país antes da edição da LRF foram significativamente reduzidos e equacionados nos primeiros anos de sua vigência. O fim das políticas clientelistas e eleitoreiras, das despesas desprovidas de legitimidade, do desequilíbrio entre receitas e despesas públicas (e a consequente geração de deficits impagáveis a partir de dívidas sem lastro) foram alguns dos principais objetivos da LRF (ABRAHAM, 2018, p. 386).

Então, por que o caos e a irresponsabilidade fiscal não foram equacionados de modo sustentável? Por que "o desequilíbrio entre receitas e despesas (e a consequente geração de deficits impagáveis a partir de dívidas sem lastro)" voltou a ser a tônica da gestão fiscal brasileira duas décadas depois?

Tem-se a diretriz necessária para as respostas a essas indagações na constatação feita por Marcus Abraham, ${ }^{22}$ ao trazer a análise da Lei de Responsabilidade Fiscal a valor presente:

Após um fecundo período de correção de rumos nas finanças públicas nacionais pautado pela busca do equilíbrio fiscal, os últimos anos de aplicação da LRF têm demonstrado que a falta de rigor no respeito de suas normas pode trazer sérios riscos para a economia e para a sociedade brasileira, impondo-se uma efetiva mudança de cultura fiscal e postura do gestor público (ABRAHAM, 2018, p.

\footnotetext{
${ }^{21}$ Ob. cit.

${ }^{22}$ Ob. cit.
} 
386) (grifos nossos).

Evidentemente, só uma cegueira deliberada seria capaz de não ver o caos fiscal que se está a viver no Brasil em sua história recente, o qual já se alonga demasiadamente sem uma solução definitiva.

Ademais, como sói haveria de ser, esse quadro caótico está imbrincado com os caminhos tomados pela interpretação e pela aplicação das normas de responsabilidade fiscal ao longo da existência da lei, com acentuado desvirtuamento de suas normas nos anos mais recentes.

Como realidade fática, a verificação dessa afirmação é de simples observação, ao menos no que tange aos efeitos mais claros desse fenômeno, notadamente a longeva crise fiscal vivenciada pela União e a grande quantidade de estados da Federação invariavelmente impactados com gastos de pessoal superiores aos limites impostos pela Lei de Responsabilidade Fiscal - acima do limite total de despesas com pessoal inclusive.

Conjugada a "falta de rigor no respeito das normas de responsabilidade fiscal" com a persistente tendência ao aumento de entropia das finanças públicas brasileiras - em indesejável paralelo com a segunda lei da termodinâmica -, era inexorável a crise econômica e fiscal que se arrastava em todas as latitudes do país.

De fato, acaso não seja revisto o trato da responsabilidade fiscal pelas instituições responsáveis pela sua concretização, o caos fiscal ressurgirá de tempos em tempos no Brasil ${ }^{23}$ :

A grave crise econômica e fiscal que o Brasil enfrentou, sobretudo nos anos de 2015 e 2016, não apenas no cenário conturbado que o Governo Central passou, sobretudo com a discussão das pedaladas fiscais, mas também com a decretação do Estado de Calamidade Fiscal pelo Rio de Janeiro e Rio Grande do Sul, foram fatos que chamaram à atenção de todos para a importância do respeito às regras da LRF (ABRAHAM, 2018, p. 386, nota de rodapé $\mathrm{n}^{\circ} 13$ ).

E assim o é, pois:

Em termos concretos, nesse período, viram-se dezenas de bilhões de reais sendo renunciados por políticas de desoneração fiscal sem a devida compensação financeira, como exige a LRF (art. 14); despesas com pessoal dos entes ultrapassaram em muito os limites previstos em lei (art. 19, LRF); o desequilíbrio financeiro e o descumprimento de metas fiscais tornam-se rotina em vilipêndio do normativo fiscal (arts. $1^{\circ}$ e $4^{\circ}$ da LRF); e o assustador gigantismo da dívida pública passou a afrontar os seus princípios legais (arts. 30 e 31 da LRF) (ABRAHAM, 2018, p. 386, nota de rodapé $n^{\circ} 13$ ).

\footnotetext{
${ }^{23}$ ABRAHAM, Marcus. Curso de Direito Financeiro Brasileiro, 5ª edição. Rio de Janeiro: Forense, 2018.
} 
Outrossim, não há qualquer perspectiva tangível de equacionamento do caos financeiro decorrente dessa persistente realidade, o qual foi formalmente reconhecido por decretação de estado de calamidade fiscal a diversos entes da Federação e que vem se agravando desde os anos de $2015^{24}$ e $2016^{2526}$.

Sem sombra de dúvida, esse problema permanece sem solução até o ano de 2019, sem que haja mudança visível no horizonte de curto prazo, inclusive, com essa circunstância registrada em documentos oficiais, tais como relatórios da Secretaria do Tesouro Nacional (SECRETARIA DO TESOURO NACIONAL, 2019), da Instituição Fiscal Independente e do Banco Mundial (BANCO MUNDIAL, 2019), em consonância com o quadro descrito no item 1.2 desta tese.

Isso posto, há de perquirir-se como nos afastamos de maneira tão profunda do quanto pretendido pelo legislador ao fincar o marco da responsabilidade fiscal no ordenamento jurídico brasileiro. A partir do diagnóstico das causas, será possível combatê-las e retirar os efeitos indesejados do mundo jurídico.

Com esse desiderato, observa-se que, em regra, tem sido lugar comum associar essa progressão de ofensas aos limites estabelecidos pela Lei de Responsabilidade Fiscal à crise vivenciada pelo Brasil a partir de 2014, como algo que será superado à medida que a economia retome o trilho do crescimento.

Fernando Rezende ${ }^{27}$ delineia esta perspectiva de modo cirúrgico:

O Brasil convive com a ilusão de que os desajustes fiscais são o resultado de uma conjuntura econômica adversa, que repercute na arrecadação de impostos e na capacidade de o governo equilibrar as contas. Todos parecem acreditar que uma retomada do crescimento será capaz de repor as coisas no eixo.

Essa é a mensagem que o governo busca transmitir à população. Se tivesse sido bem-sucedido, o ajuste de 2015 teria aberto o caminho para que a economia voltasse a crescer no ano de 2016 e a situação se normalizasse (REZENDE, 2016, p. 49).

\footnotetext{
24 Ao final do ano de 2015, os limites de gastos com pessoal haviam sido ultrapassados por 13 estados da Federação e pelo Distrito Federal, conforme matéria publicada na Agência Brasil (EBC): “Crise faz 13 estados e o DF estourarem limite de gastos com pessoal'. Disponível em:

http://agenciabrasil.ebc.com.br/economia/noticia/2015-12/crise-faz-13-estados-e-df-estourarem-limite-degastos-com-pessoal

${ }^{25}$ Ao longo de 2016, a situação de comprometimento em face dos limites da Lei de Responsabilidade Fiscal expandiu-se e englobou novos estados da Federação, conforme matéria publicada pelo Jornal o Estado de São Paulo: "Gastos com pessoal extrapolam limites - Segundo especialista, 21 estados comprometeram mais de $65 \%$ das receitas com pessoal e serviços da dívida". Disponível em:

http://economia.estadao.com.br/noticias/geral,gastos-com-pessoal-extrapolam-limite, 10000048269

${ }^{26} \mathrm{Na}$ mesma linha de agravamento do comprometimento com os limites de gastos de pessoal, tem-se matéria publicada no Site Contas Abertas: "Em crise, 17 estados e DF fecharam 2015 com gastos de pessoal acima do limite da LRF.” Disponível em:

http://www.contasabertas.com.br/website/arquivos/12857

${ }^{27}$ REZENDE, Fernando. Em busca do tempo perdido: é preciso buscar o fio da meada para desembaraçar o novelo fiscal. Rio de Janeiro: FGV Editora, 2016.
} 
Evidentemente, essa é uma resposta simplista para um problema complexo, consoante o caminho apontado por Fernando Rezende, ${ }^{28}$ ao analisar a tentativa de resumir o problema a uma crise econômica:

Ledo engano. A retração dos negócios agrava os problemas, mas não corrige as causas estruturais dos desequilíbrios. Na melhor das hipóteses, a situação deixa de piorar, como foi exaustivamente demonstrado em estudos recentes (REZENDE, 2016, p. 49).

De fato, "as raízes estruturais do desajuste das contas públicas são profundas" (REZENDE, 2016), o que requer que cavemos mais fundo para encontrar essa indesejável fonte.

Assim, a presente tese trabalha com a hipótese de que uma das "raízes estruturais do desajuste das contas públicas" seja oriunda de falhas sistêmicas no regime jurídico de controle de despesas com pessoal, em linha com a supracitada "falta de rigor na aplicação das normas de responsabilidade fiscal”.

Vale dizer, a recorrente dificuldade de contenção dessas relevantes despesas obrigatórias de caráter continuado dentro dos limites estabelecidos pela Lei de Responsabilidade Fiscal - entre outras engrenagens ativas do patente caos financeiro que se está a vivenciar - induz à constatação de que a aplicação até aqui dada à lei não tem traduzido com exatidão os princípios e normas extraíveis de seu texto em cotejo com a Constituição da República e as demais normas componentes do regime jurídico financeiro.

Dessarte, objetivamente, são as seguintes contribuições originárias à ciência jurídica que o presente projeto de pesquisa se propõe a alcançar: a) diagnóstico dos pontos de estrangulamento do regime jurídico do controle de despesas com pessoal, traduzíveis em falhas sistêmicas; b) delineamento de um regime do controle de despesas com pessoal adequado à concretização dos valores jurídicos inerentes ao regime jurídico financeiro; c) interpretação sistemática dos dispositivos atinentes ao controle de despesas com pessoal, de como que seus institutos se concretizem em uma unidade lógica e coerente; d) harmonização do controle de despesas com pessoal com as modificações levadas a cabo pela Lei de Introdução às Normas do Direito Brasileiro (LINDB) ${ }^{29}$.

Para tanto, será necessário fixar conceitos centrais como os definidos no Capítulo II,

\footnotetext{
${ }^{28}$ Ob. cit.

${ }^{29}$ DECRETO-LEI N ${ }^{\circ}$ 4.657, DE 4 DE SETEMBRO DE 1942, com os dispositivos incluídos pela Lei ${ }^{\circ} 13.665$, de 25 de abril de 2018.
} 
inclusive com definições mais adequadas ao estágio atual do regime jurídico financeiro, além da adequada contextualização do momento vivido pelas finanças públicas e pelo Direito Financeiro.

Outrossim, tem-se como eixo central aferir a correta aplicação das normas de Direito Financeiro atinentes à responsabilidade fiscal, notadamente perquirindo a essência de seus dispositivos, os quais deverão ir além do mero texto expresso normativo, de modo que haja um eficaz regime jurídico de controle de despesas com pessoal.

Dessarte, busca-se uma interpretação sistemática das normas componentes desse regime, de forma a orientar a sua melhor aplicação, contribuindo com o aperfeiçoamento normativo e acadêmico sobre a matéria, de modo a conter as condutas incompatíveis com seus princípios e valores.

Infelizmente, no que tange às despesas públicas, tem-se profunda carência quanto ao estudo sistemático de seus institutos, com efeitos colaterais nocivos para a qualidade do gasto público, consoante lição de Joaquim Freitas da Rocha ${ }^{30}$ :

Importa ter presente que, historicamente, os currículos universitários não têm consagrado a devida atenção ao estudo dos gastos públicos como o demonstram explicitamente expressões como 'parent pauvre' das finanças públicas, 'tema menor', ou ainda 'una de las cuestiones más abandonada por la doctrina', com consequências bastante negativas ao nível de formação dos estudantes em geral, dos juristas em particular, dos decisores políticojurídicos e das próprias gerações futuras (ROCHA, 2019, p. 40).

Ademais, ainda há muita insegurança jurídica quanto ao exato teor dos comandos normativos atinentes à despesa pública, em face da "ausência de estudos aprofundados e sistematizados sobre o direito dos gastos públicos, não só aqui no Brasil como também no exterior" (GOMES, 2015, p. 22) . $^{31}$.

De fato, o problema é patente, o que requer esforços sistematizadores da doutrina, consoante salientado por Emerson Cesar da Silva Gomes ${ }^{32}$ :

A carência de estudos jurídicos sistematizados constitui um incentivo ao uso irracional e o desvio de recursos públicos. Em muitos casos, a ausência de comandos claros sobre o que é permitido, sobre o que é proibido e sobre o que é obrigatório no tocante à gestão de recursos públicos facilita a conduta do gestor de má-fé e dificulta o enforcement das regras jurídicas pertinentes.

$\mathrm{Se}$, em relação a algumas regras claras, é difícil executar o controle financeiro, imagine como é difícil impor o respeito aos princípios jurídicos do gasto público, que, pela sua própria natureza, são mais abstratos, vagos e indeterminados (GOMES, 2015, p. 22).

\footnotetext{
${ }^{30}$ ROCHA, Joaquim Freitas da. Direito da Despesa Pública. Coimbra: Almedina, 2019.

${ }^{31}$ GOMES, Emerson Cesar da Silva. O Direito dos Gastos Públicos no Brasil. São Paulo: Almedina, 2015.

${ }^{32}$ Ob. cit.
} 
Ao longo desse trabalho, em muitas circunstâncias será necessário caminhar em direção a mudanças legislativas e de orientação jurisprudencial, inclusive no âmbito dos Tribunais de Contas, de maneira que a responsabilidade fiscal, alicerçada no regime jurídico financeiro, seja traduzida efetivamente em mecanismo para a realização do interesse público primário.

Ademais, é inexorável aferir-se empiricamente a eficácia das normas atinentes aos limites de gastos com pessoal estabelecidos na Lei de Responsabilidade Fiscal, notadamente no que tange às vedações inerentes ao limite prudencial, bem como os eventuais efeitos deletérios para a realização do interesse público primário diante de sua prolongada aplicação ao longo do tempo.

Dessa forma, visa-se o aperfeiçoamento do controle das despesas com pessoal, construindo um arcabouço teórico apto a nortear a aplicação de princípios e normas do seu respectivo regime a casos de difícil solução, em face do agravamento do desequilíbrio das despesas públicas com pessoal na União e em diversos estados da Federação, uma vez que essas não foram efetivamente contidas por anos a fio ao longo da última década.

\subsection{EQUILÍBRIO ENTRE MEIOS E FINS DO ESTADO}

À evidência, para que o Estado bem exerça a sua atividade financeira e efetive as finalidades inerentes às suas funções, faz-se obrigatório um adequado e correto equilíbrio entre receitas e despesas públicas, sobretudo quando se está a falar de uma despesa com as características dos gastos com pessoal.

De fato, esse tipo de despesa pública requer especial atenção de um Direito Financeiro calcado em responsabilidade fiscal, notadamente nos termos delineados pela Lei de Responsabilidade Fiscal, haja vista que: i) esses gastos se prolongam, via de regra, por diversos anos a partir de sua efetivação primeira; ii) crescem de modo vegetativo; iii) possuem incrível resistência inercial para serem reduzidos; e iv) classificam-se entre as despesas obrigatórias de caráter continuado, com o agravante de serem insuscetíveis de limitação de empenho.

De fato, há de se ter sempre em mente o quanto disposto no art. 17 da Lei de Responsabilidade Fiscal e as nuances atinentes às despesas enquadradas em sua previsão normativa: 
Art. 17 Considera-se obrigatória de caráter continuado a despesa corrente derivada de lei, medida provisória ou ato administrativo normativo que fixem para o ente a obrigação legal de sua execução por um período superior a dois exercícios.

A potencializar ainda mais a complexidade destas despesas cujos efeitos se protraem no tempo, tem-se a vedação prevista no art. $9, \S 2^{\circ}$ da Lei de Responsabilidade Fiscal:

art. $9^{\circ}$ Se verificado, ao final de um bimestre, que a realização da receita poderá não comportar o cumprimento das metas de resultado primário ou nominal estabelecidas no Anexo de Metas Fiscais, os Poderes e o Ministério Público promoverão, por ato próprio e nos montantes necessários, nos trinta dias subseqüentes, limitação de empenho e movimentação financeira, segundo os critérios fixados pela lei de diretrizes orçamentárias.

(...)

$\S 2^{\circ}$ Não serão objeto de limitação as despesas que constituam obrigações constitucionais e legais do ente, inclusive aquelas destinadas ao pagamento do serviço da dívida, e as ressalvadas pela lei de diretrizes orçamentárias.

A título de exemplo, a demonstrar as dificuldades inerentes à gestão das despesas com pessoal, cite-se a tentativa do Governo Federal fazer o ajuste fiscal via corte de despesas, sobretudo no ano de 2015, conforme descrito por Fernando Rezende ${ }^{33}$ no livro "Em busca do tempo perdido: É preciso buscar o fio da meada para desembaraçar o novelo fiscal":

O contato direto com a realidade fez com que prevalecesse o pragmatismo na condução da política fiscal, à medida que foi ficando claro que as economias esperadas com a contenção das despesas seriam bem menores do que o previsto, em face das manifestações contrárias dos setores que seriam afetados e de figuras expressivas do Congresso. As atenções se voltaram, então, para a busca de novas formas de aumentar a arrecadação, pois o que era inicialmente previsto nessa área também não ocorreu.

(...) Do lado das despesas, nenhuma das medidas anunciadas foi aprovada a tempo de afetar significativamente o resultado observado no início daquele ano. Não por acaso, o resultado primário do governo central nos primeiros cinco meses de 2015 foi o pior dos últimos 25 anos (REZENDE, 2016, p. 26).

Dessarte, é inexorável para uma gestão fiscal efetivamente responsável aferir constantemente a geração e a evolução de despesa pública com as características supra apontadas.

Mas, isso só será possível se o regime jurídico atinente a essas despesas estiver bem vincado, de sobremaneira no que concerne ao controle; de modo que, entre outras implicações, as consequências jurídicas da superação dos limites de gastos com pessoal sejam adequadamente extraídas de todo o ordenamento jurídico e não apenas de uma norma isolada da Lei de Responsabilidade Fiscal, enfatizando o sistema em detrimento das soluções ad hoc

${ }^{33}$ REZENDE, Fernando. Em busca do tempo perdido: é preciso buscar o fio da meada para desembaraçar o novelo fiscal. Rio de Janeiro: FGV Editora, 2016. 
que são extraídas atualmente com insólita frequência.

Ademais, os limites de gastos com pessoal têm sido enfatizados apenas sob o ponto de vista financeiro, sem que sejam observadas detidamente as nuances atinentes ao interesse público primário realizado ou impedido de ser realizado em função da aplicação desses limites.

Dessarte, somam-se aos demais pontos destacados de importância e atualidade do tema os indícios de falhas sistêmicas no regime jurídico de controle das despesas com pessoal, bem como a necessidade de uma análise mais abrangente da responsabilidade fiscal, englobando as nuances da atividade financeira e as finalidades inerentes ao exercício das funções estatais.

Porém, ao lado desses aspectos centrais da tese ora apresentada, não se pode olvidar que o equilíbrio entre receitas e despesas, núcleo essencial da limitação de gastos com pessoal, não é um fim em si mesmo. Ao revés, a atividade financeira do Estado, de modo geral, já é por si só meio para a consecução de necessidades públicas maiores, cristalizadas em interesses públicos primários.

De fato, em consonância com Carlos Maurício Figueiredo e Macos Nóbrega ${ }^{34}$ :

Assim, aplicar a Lei de Responsabilidade Fiscal utilizando de forma monolítica suas regras é tocar instrumento para surdos. O amálgama da dua aplicabilidade deve voltar-se por outro princípio de direito que é o princípio da razoabilidade. (...) Trata-se de um conceito metajurídico, da busca de um valor do direito que é a justiça. Dessa forma, razobilidade pode ser resumida como ponderação, o meio existente entre o ônus imposto e o benefício alcançado (FIGUEIREDO, et al., 2006, p. 73).

Portanto, a ponderada interpretação da LRF pressupõe adequação específica aos valores que lhe são próprios, sem descurar, todavia, do princípio do interesse público que rege todo o direito público.

Em assim sendo, segue-se na esteira de Carlos Maurício Figueiredo e Marcos Nóbrega ${ }^{35}$ :

Dessa maneira, interpretar a LRF não é possível sem apego a esses princípios, e é aí que pecam muitos daqueles que, de forma açodada, tentam interpretar a Lei de Responsabilidade Fiscal à luz fria do texto legal, sem atenção devida aos valores que dão sustentabilidade para sua perfeita exegese (FIGUEIREDO, et al., 2006, p. 73).

Diante disso, há sempre que se ter em mente que controle e limitação de despesas públicas são nuances da realização do interesse público. No entanto, configuram interesses

\footnotetext{
${ }^{34}$ FIGUEIREDO, Carlos Maurício; NÓBREGA, Marcos. Lei de Responsabilidade Fiscal: aspectos polêmicos. Belo Horizonte: Fórum, 2006.

${ }^{35}$ Idem ibidem.
} 
públicos secundários, instrumentais para a realização de finalidades públicas essenciais, como o desenvolvimento sustentável e a prestação de serviços públicos, esses sim plasmados no interesse público primário.

Dessarte, faz-se necessário, para o adequado controle de despesas públicas, em geral e especificamente as despesas com pessoal, compreender a exata acepção do que seja um equilíbrio entre receitas e despesas ou equilíbrio orçamentário-fiscal.

À evidência, para que se possa aferir economicidade, eficiência, sustentabilidade financeira de um determinado gasto público ou conjunto de gastos - ou seja, a sua validade perante o regime jurídico financeiro -, é imprescindível o cotejo dela com os meios disponíveis para a sua realização, consoante palavras do Prof. Marcus Abraham ${ }^{36}$ :

\subsection{O equilíbrio orçamental \\ (...)}

Tal equilíbrio é considerado a 'regra de ouro' tanto na Lei de Responsabilidade Fiscal brasileira ( $\left.\mathrm{LC} \mathrm{n}^{\circ} 101 / 2000\right)$ como na legislação portuguesa, com destaque para a nova Lei de Enquadramento Orçamental e o Pacto Orçamental Europeu, que o denominam de "estabilidade orçamental". Este parâmetro representa a fórmula para que o Estado possa dispor de recursos necessários e suficientes à realização da sua atividade, sem ter de sacrificar valores tão importantes como a estabilidade nas contas públicas com contenção da inflação, a credibilidade do país no mercado financeiro internacional pela administração do endividamento público externo e, principalmente, a efetividade do orçamento, como verdadeiro instrumento de planejamento e não como 'peça de promessas fictícias, em que, num passado não muito remoto, se incluíam todas as pretensões governamentais sem a preocupação de se identificar os recursos para viabilizar a sua realização (ABRAHAM, 2019, p. 141-142).

No entanto, nada obstante a inexorável e imprescindível correlação entre receitas e despesas, esse cotejo não há de traduzir-se imperiosamente em uma conta de chegada zero, mas, sim, em um equilíbrio sustentável ao longo do tempo.

No que tange à dinâmica dessa relação, assim se pronuncia o Prof. Marcus Abraham ${ }^{37}$ :

Não se trata, contudo de uma equação matemática rígida, em que a diferença numérica entre o montante de receitas e despesas deva ser sempre igual a zero, mas sim que essa equação contenha valores estáveis e equilibrados, a fim de permitir a identificação dos recursos necessários à realização dos gastos. Representa uma relação dinâmica e balanceada entre meios e fins (ABRAHAM, 2019, p. 142).

Isso conduz o doutrinador ${ }^{38}$ a associar o equilíbrio fiscal com a estabilidade financeira e a sustentabilidade do Estado, haja vista a imperiosidade de se calibrar meios disponíveis

\footnotetext{
36 ABRAHAM, Marcus. Governança fiscal e sustentabilidade financeira: os reflexos do Pacto Orçamental Europeu em Portugal como exemplos para o Brasil. Belo Horizonte: Fórum, 2019.

${ }^{37}$ Ob. cit.

${ }^{38}$ Ob. cit.
} 
com os fins a serem perseguidos. Assim:

O equilíbrio fiscal representa a verdadeira estabilidade financeira e é um dos pilares do crescimento sustentado do Estado. Isso porque, antes de ser mera equação financeira em que se busca uma igualdade numérica ou um 'empate' entre receitas e despesas, esse princípio deve ser encarado como um conjunto de parâmetros que confiram às contas públicas a necessária e indispensável estabilidade, a fim de permitir ao Estado a realização de suas finalidades, embasando-se tanto no dever essencial ou fundamental de contribuir como no poder-dever de arrecadar, pelo lado da receita, como no dever de gastar adequadamente e conforme previsto no orçamento público, pelo lado da despesa (ABRAHAM, 2019, p. 142).

Em consonância com esse pensamento, há de registrar-se que a arrecadação é interesse público secundário e esse só é efetivamente interesse público se, e somente se, atrelado à realização de um interesse público primário (BANDEIRA DE MELLO, 2019, p. 66).

Nessa mesma direção, tem-se a doutrina do Prof. Régis Fernandes de Oliveira ${ }^{39}$ :

\begin{abstract}
Ao lado das necessidades denominadas primárias de cada indivíduo (segurança, saúde, educação etc.), devem ser identificadas as necessidades primárias públicas. Em relação à União as mencionadas no art. 21, e outras esparsas ao longo da Constituição (saúde, educação, ensino, cultura etc.).

Estes são objetivos que o Estado busca atingir. Mas, como disse Rui Barbosa, quem dá os fins dá os meios. Não é possível estabelecer deveres ao Estado sem que ele detenha recursos para atendê-los.

Daí o conceito de necessidades secundárias ou instrumentais, isto é, o Estado deve manter uma estrutura arrecadatória (inciso XXII do art. 37 da CF para alimentar os cofres públicos de recursos, que, por sua vez, serão utilizados na prestação de atividades tendentes a atender às necessidades primárias (OLIVEIRA, 2019, p. 180).
\end{abstract}

Portanto, não se pode conceber que a limitação de gastos com pessoal possa ao mesmo tempo realizar o interesse público e causar a paralisia da Administração Pública, deixando-a incapaz de alcançar os deveres-poderes que justificam a sua existência.

Nessa linha, corrobora-se o posicionamento do prof. Régis Fernandes de Oliveira (OLIVEIRA, 2019, p. 691), o qual destaca, ao analisar intelecção do Tribunal de Contas do Rio Grande do Sul, que as limitações impostas pela Lei de Responsabilidade Fiscal norteiam-se pela defesa e pela realização do interesse público, sem que sua aplicação deva ocasionar a paralisação da Administração Pública.

Ora, o ordenamento jurídico, na concepção de Norberto Bobbio (BOBBIO, 1995, p.78), rechaça a contradição de permitir uma conduta e, ao mesmo tempo, impor dever com ela incompatível. Portanto, não se pode conceber que a lei almeje que uma finalidade seja

\footnotetext{
${ }^{39}$ OLIVEIRA Régis Fernandes de. Curso de Direito Financeiro, 8a edição. São Paulo: Malheiros, 2019.
} 
alcançada pela Administração Pública e, ao mesmo tempo, retire-lhe em absoluto os meios necessários a essa concretização.

Vale dizer, haja vista tratar-se de um dever-poder da Administração realizar o interesse público primário, essa prescrição normativa consubstancia-se no modal deôntico obrigatório, o qual traz em sua essência que o mesmo ordenamento jurídico que determina uma conduta não imponha a obrigação de realizar conduta diversa excludente da primeira.

Assim, tem-se igualmente como desafio central a que se propõe esta tese o equalizar a interpretação dos limites de gastos com pessoal com o interesse público a ser realizado, o que poderá nos levar a uma situação de necessidade de incremento de despesa, ainda que os gastos com despesa de pessoal tenham superado o limite prudencial da Lei de Responsabilidade Fiscal, atraindo para tanto medidas compensatórias nos moldes previstos para as renúncias de receitas, tal qual previsto no art. 14, inciso II, da Lei Complementar $\mathrm{n}^{\circ}$ 101/00.

Observe-se que a jurisprudência já evoluiu para reconhecer que os limites de gastos com pessoal não podem servir de obstáculos para a concretização de direitos subjetivos, notadamente decorrentes de lei ou decisão judicial, os quais foram parcialmente excepcionados pelo art. 22, parágrafo único, da Lei de Responsabilidade Fiscal - a exceção expressa na lei limita-se à concessão de vantagem, aumento, reajuste ou adequação de remuneração a qualquer título, não se estendendo, por exemplo, ao provimento de cargos.

Nesse sentido, assim se posicionou o Superior Tribunal de Justiça ${ }^{40}$ :

Os limites previstos nas normas da Lei de Responsabilidade Fiscal (LRF) mormente os relacionados às despesas com pessoal de ente público - não são aptos a justificar o descumprimento dos direitos subjetivos do servidor público, como é o recebimento de vantagens asseguradas por lei (cf. art. 22, parágrafo único, da LC 101/2000).

Evoluindo esse raciocínio, se os direitos subjetivos são categorias jurídicas aptas a excepcionar as limitações da Lei de Responsabilidade Fiscal, não seria razoável supor que essas seriam barreiras intransponíveis à realização das finalidades precípuas da Administração Pública.

Todavia, no caso da necessidade de consecução de um interesse público específico, obstaculizado pelas limitações decorrentes da superação dos limites da Lei de Responsabilidade Fiscal, a hipótese não seria de excepcionar as normas de contenção, mas equilibrar, ponderar, o interesse público primário e o secundário.

\footnotetext{
${ }^{40}$ AgRg em RMS 30.359/RO, 5 T., j. 04.10.2012, rel. Min. Marco Aurélio Bellizze, Dje 11.10.2012. AgRg no RMS 30.451/RO, j. 19.06.2012, rel. Min. Maria Thereza de Assis Moura, Dje 29.06.2012
} 
Para tanto, não se pode conceber que inexista um prazo para a permanência dos gastos de pessoal de uma determinada Administração Pública em patamares superiores aos limites da Lei de Responsabilidade Fiscal, notadamente os limites de alerta e prudencial; pois a contínua aplicação das vedações de aumento de despesas com pessoal - na hipótese de ter sido ultrapassado o limite prudencial -, em especial as que impedem o provimento de novos cargos, inexoravelmente implicarão na inviabilização do alcance de diversos interesses públicos primários.

À evidência, é uma contradição lógica, ofensiva à Teoria do Ordenamento Jurídico, permitir que a ultrapassagem dos limites de despesas com pessoal protraia-se indefinidamente no tempo, com a simultânea imposição do dever de realizar finalidades públicas, sendo que essas são gradativamente impossibilitadas de serem alcançadas pela continuidade desse estado de coisas.

Ademais, consoante lição do prof. Celso Antônio Bandeira de Mello ${ }^{41}$ (BANDEIRA DE MELLO, 2006, p. 36-37), a existência de discricionariedade na hipótese abstrata da norma não implica necessariamente na ocorrência de mais de uma escolha juridicamente válida quando da aplicação concreta da norma, haja vista sempre se pressupor a solução ótima para a Administração Pública.

Além de não implicar que todas as condutas abstratamente válidas na previsão normativa sejam igualmente válidas diante das circunstâncias do caso concreto, nesses termos, assim lê-se na doutrina do Prof. Celso Antônio ${ }^{42}$ :

Com efeito, se a lei comporta a possibilidade de soluções diferentes, só pode ser
porque pretende que se dê uma certa solução para um dado tipo de casos e outra
solução para outra espécie de casos, de modo a que sempre seja adotada a
decisão pertinente, adequada à fisionomia própria de cada situação, tendo em
vista atender a finalidade que inspirou a regra de direito aplicanda.
A existência de uma variedade de soluções comportadas em lei outorgadora de
discrição evidentemente não significa que esta considere que todas estas
soluções são igual e indiferentemente adequadas para todos os casos de sua
aplicação. Significa, pelo contrário, que a lei considera que algumas delas são
adequadas para alguns casos e que outras delas são adequadas para outros casos
(BANDEIRA DE MELLO, 2006, p. 36/37).

Ou seja, trazendo essas lições para o regime jurídico do controle de gastos com pessoal: o fato de a Lei de Responsabilidade Fiscal não ter estabelecido um prazo limite para a permanência dessa espécie de gastos acima dos limites de alerta e prudencial - o que abstrata

\footnotetext{
${ }^{41}$ BANDEIRA DE MELLO, Celso Antônio. Discricionariedade e Controle Jurisdicional, $2^{a}$ edição. - São Paulo: Malheiros, 2006.

${ }^{42}$ Ob. cit.
} 
e inicialmente comportaria juízo de conveniência e oportunidade sobre o retorno desse dispêndio a patamares de menor comprometimento da receita corrente líquida -, não há de ser lido como salvo conduto para perpetuar indefinidamente essa situação insustentável a longo prazo.

Obviamente, permanecer além dos limites de alerta e prudencial da Lei de Responsabilidade Fiscal, acaso encarado como situação jurídica normal, traz não apenas o risco de ultrapassar o limite legal à primeira contingência financeira vindoura, com incremento de riscos fiscais que deveriam ser evitados, mas, também, o efeito colateral de deteriorar os serviços prestados pelos poderes públicos.

Ou seja, uma hipotética opção de permanecer além desses limites, significa potencialmente afastar-se da realização ótima do interesse público, com uma concretização menos eficaz, consoante será aprofundado no Capítulo IV desta tese.

Outrossim, não se pode olvidar nessa correlação necessária e dinâmica entre meios e fins do Estado, a Teoria da Constituição Financeira delineada pelo Prof. Heleno Torres ${ }^{43}$ (TORRES, 2014, p. 71/115), com os parâmetros nela traçados para escolhas públicas diante de limites de gastos juridicamente impostos, notadamente diante da realização dos princípios do Estado Social da Constituição da República de 1988.

Em arremate, a concepção doutrinária de gestão fiscal responsável pressupõe a prevenção de riscos fiscais, inclusive com atitudes proativas, incompatíveis com uma postura de perpetuação de fragilidades fiscais tendentes ao agravamento com o decurso do tempo.

Indubitavelmente, a realidade brasileira ao final desta década, notadamente com a crise das despesas com pessoal na União e nos estados da Federação, demonstra a difículdade de controle das despesas públicas, bem como a imperiosidade de contê-las em equilíbrio com as receitas, o que induz à imperiosidade de ser adequadamente traçado o regime jurídico do controle de despesas com pessoal.

Infelizmente, enquanto os estudos avançaram no Brasil no que tange às receitas públicas, notadamente as de origem tributária, as despesas não tiveram até então o mesmo desenvolvimento acadêmico, nada obstante esforços recentes, como a tese de Emerson Cesar da Silva Gomes ${ }^{44}$, a qual redundou no livro o Direito dos Gastos Públicos no Brasil (GOMES,

\footnotetext{
${ }^{43}$ TORRES, Heleno Taveira. Direito Constitucional Financeiro: teoria da constituição financeira. São Paulo: Revista dos Tribunais, 2014.

${ }^{44}$ GOMES, Emerson Cesar da Silva. O Direito dos Gastos Públicos no Brasil. São Paulo: Almedina, 2015.
} 
$2015)^{45}$

Isso se dá mesmo com o advento da Lei de Responsabilidade Fiscal, na qual o controle da despesa pública recebe especial atenção, mas encontra inúmeros obstáculos para a sua efetivação, a começar pelo poder público ordenador da despesa, atingindo também os órgãos de controle.

Além da resistência a dar plenitude aos dispositivos da Lei de Responsabilidade Fiscal que buscam conter as despesas públicas em patamares sustentáveis, como é o caso das medidas a serem tomadas inexoravelmente quando seja ultrapassado o limite de gastos com pessoal, tem-se igualmente uma pluralidade de interpretações procedidas pelos Tribunais de Contas, sem que haja uma uniformização de sua aplicação no âmbito nacional - conforme aprofundando nos itens 1.2, 1.3 deste Capítulo I e no Capítulo V desta tese.

Esse quadro foi percucientemente delineado por Marcus Abraham ${ }^{46}$, cuja advertência cirúrgica há de ser trazida a lume:

Não se esqueça também da necessária padronização e harmonização conceitual para se permitir a devida aplicação e efetividade da norma, mormente em razão de que os Tribunais de Contas, sobretudo dos Estados, ainda não têm uma interpretação uniforme de vários dispositivos da LRF (ABRAHAM, 2019, p. 72).

Assim, tem-se estados nos quais o imposto de renda retido na fonte é retirado do cálculo com despesas com pessoal, outros excluem ad eternum despesas decorrentes de ordem judicial, outros ainda não incluem despesas com terceirização que sejam substitutivas de cargos públicos, entre tantas outras hipóteses, de modo que a eficácia do controle de despesas com pessoal vai sendo ostensivamente mitigada.

Vale dizer, invariavelmente, os Tribunais de Contas criam "atalhos interpretativos" os quais culminam em "permitir a alguns gestores públicos encontrarem caminhos alternativos para superar as limitações e condicionantes da lei e, sobretudo, para não verem aplicadas contra si as sanções pelo seu descumprimento.” (ABRAHAM, 2019, p. 72). ${ }^{47}$

Por via de consequência, mitigam-se os pilares da responsabilidade fiscal, com uma artificial roupagem de cumprimento formal dos seus dispositivos, quando se está a realizar as

\footnotetext{
${ }^{45}$ A existência de um novo ramo jurídico a ser denominado "direito dos gastos públicos" ou "direito da despesa pública" é discutida no item 1.6 desta tese.

${ }^{46}$ ABRAHAM, Marcus. Reflexões sobre finanças públicas e direito financeiro. Salvador: Editora JusPodivm, 2019.

${ }^{47}$ Ob. cit.
} 
condutas indesejadas pelo sistema jurídico financeiro.

Diante dessa constatação, reforça-se o entendimento de que não se pode tomar a Lei de Responsabilidade Fiscal como o ponto culminante do sistema fiscal, descurando da imperiosidade de novos avanços a serem feitos, de modo a atingir a plena concretização da gestão fiscal responsável.

Para convergir nesse sentido, o aperfeiçoamento sistêmico e institucional é inexorável, consoante delineado por Cristiane Kerches da Silva Leite ${ }^{48}$ em sua tese de doutorado:

\begin{abstract}
A sanção desta lei não foi o último capítulo do processo de ordenamento fiscal. Este processo está longe de se consumar. Aliás, trata-se de um processo de contínua construção institucional, que envolve, entre outras coisas, o aprimoramento de uma rede de instâncias públicas para realizar efetivamente o controle dos gastos e do endividamento público, que inclui os Tribunais de Contas, encaminhando as punições legalmente cabíveis. Contudo, acreditamos que foi um capítulo relevante ao sistematizar e criar novas regras para ordenar o processo orçamentário, controlar gastos públicos e nível de endividamento dos entes federativos (LEITE, 2005, p. 16).
\end{abstract}

Em assim sendo, com as disfuncionalidades sistêmicas do sistema de controle, as despesas públicas, em especial as despesas com pessoal, vão se afastando do atingimento da finalidade pública, ensejando uma máquina administrativa cada vez mais inchada e de todo destoante da capacidade da sociedade de arcar com ela, como se fosse um fim em si mesmo, em que se gasta muito e se gasta mal.

Diante desse quadro, apresenta-se como necessária a imposição de um teto de gastos, com efeitos mais contundentes para refrear esse estado de coisas, mas que corre o risco de ter o mesmo destino de muitas das normas da Lei de Responsabilidade Fiscal, pois já se fala em flexibilizá-lo ou, simplesmente, não haver a possibilidade de cumpri-lo.

Qualquer que seja o caminho a ser trilhado, o fato é que o país não comporta mais conversão de deficit público em endividamento, comprometendo cada vez mais as gerações futuras, sem que haja a entrega adequada de atividades necessárias para a concretização eficiente do interesse público.

\footnotetext{
${ }^{48}$ LEITE, Cristiane Kerches da Silva. O processo de ordenamento fiscal no Brasil na década de 1990 e a Lei de Responsabilidade Fiscal (Tese de doutorado). São Paulo: USP, 2005.
} 


\subsection{CONTEXTO HISTÓRICO E ECONÔMICO DAS FINANÇAS PÚBLICAS NO FINAL DA SEGUNDA DÉCADA DO SÉCULO XXI}

Desde o princípio da incerteza de Heisenberg, que invadiu a fortaleza da física aferível matematicamente por natureza -, poucas são as afirmações categóricas passíveis de serem feitas no âmbito da ciência, em especial no campo das ciências sociais e sua complexidade intrínseca.

Nada obstante essa abertura ao sempre potencial desconhecido, pode-se afirmar categoricamente que o controle de despesas com pessoal entrou em colapso no Brasil no final da segunda década do século XXI - fenômeno que abrange os três âmbitos da Federação: União, estados e municípios. E assim o é, conquanto seja possível divergir sobre o momento a partir do qual essa trajetória explosiva se iniciou ${ }^{49}$ e quais as suas causas mediatas e imediatas.

De fato, nessa quadra histórica, o comprometimento das receitas públicas além do razoável com gastos de pessoal é uma realidade presente no quotidiano da maioria dos entes da Federação, com flagrante tendência de agravamento com o alongamento da crise econômica vivida atualmente pelo país.

Nesses momentos, costumam surgir interpretações convenientes ao sabor das circunstâncias, com dinâmicas absolutamente diversas da solidez acadêmico-científica, o que torna ainda mais premente que o Direito volte seus olhos para esse fenômeno.

Nas pertinentes palavras de Joaquim Freitas da Rocha ${ }^{50}$, em obra recentemente publicada com os olhos voltados para Portugal, mas que em tudo se aproxima da realidade brasileira:

Há muito que a despesa carece do amparo do Direito, em lugar de ser largada à sua (pouca) sorte nos domínios da política, da economia (ou da öknomische Analyse des States), da gestão financeira, quando não da causalidade, da contingência ou da recorrente necessidade prática. As más despesas e os desastres despesistas são tantos que o Direito e a respectiva ciência não podem, até por imperativo ético, ficar indiferentes. (ROCHA, 2019, p. 7)

\footnotetext{
49 Sobre o tema, adequadamente descrito no livro Anatomia de um Desastre, vale refletir sobre a seguinte passagem: "Para Bernard Appy, ex-secretário de Política Econômica na gestão de Antonio Palocci na Fazenda, a virada para a irresponsabilidade fiscal ocorreu no último ano do segundo mandato de Lula. 'Em 2010, o governo pirou', disse, referindo-se à expansão dos gastos e do crédito público, quando a economia não precisava mais de estímulos, pois já havia superado a crise mundial deflagrada no segundo semestre de 2008.

Lula encerrou seus oito anos de governo com a inflação em alta, a economia superaquecida, os juros em baixa e uma piora nos resultados fiscais em relação ao período pré-crise global.” SAFATLE, Cláudia; BORGES, João e OLIVEIRA, Ribamar. Anatomia de um Desastre: Os bastidores da crise econômica que mergulhou o país na pior recessão da história (formato: e-book). São Paulo: Portfólio, 2016, posição 975, Capítulo 5. "Um momento mágico".

${ }^{50}$ ROCHA, Joaquim Freitas da. Direito da Despesa Pública. Coimbra: Almedina, 2019.
} 
Assim, o tema desta pesquisa pressupõe a análise fática de uma circunstância presente em múltiplas latitudes do país, o que requer criterioso aprofundamento neste momento específico para evitar potenciais retrocessos na responsabilidade fiscal - agora ainda mais ameaçada por flexibilizações de ocasião -, além de corrigir as falhas sistêmicas que nos conduziram até essa situação de calamidade financeira.

A olhos vistos, inúmeras são as dificuldades enfrentadas nas três esferas para arcar com as despesas obrigatórias de caráter continuado ${ }^{51}$ já contratadas, em especial as despesas com pessoal, deixando pouca ou nenhuma margem para concretizar outras obrigações estatais como investimento em infraestrutura, por exemplo.

De posse dos dados dos gastos públicos com gestão de pessoas e folha de pagamentos, assim se pronunciou o Banco Mundial ${ }^{52}$ sobre o calamitoso quadro destas despesas:

1. Em dez anos (2007-2017), o gasto com servidores públicos aumentou cerca de $48 \%$ em termos reais. Em 2017, foram gastos R $\$ 725$ bilhões com 11,5 milhões de servidores, cifra que representa cerca de $10 \%$ do PIB do país, equivalente a pouco mais de 20 vezes o gasto com o Bolsa Família.

Em 20 anos, o número de servidores aumentou cerca de $82,4 \%$, passando de 6,26 milhões para 11,5 milhões, período em que o aumento da população foi de cerca de $30 \%$.

Uma comparação internacional indica que o setor público brasileiro gasta mais do que o de países vizinhos: em 2013, enquanto o governo federal alocou cerca de $4,3 \%$ do PIB com salários, os percentuais de países como México, Colômbia e Argentina foram de 1,6\%, 2,3\% e 2,5\% respectivamente.

2. Até o início de 2019 , sete estados já haviam declarado estado de calamidade financeira, o que está refletido diariamente no atraso de pagamento de salários e na queda da qualidade dos serviços prestados à população. No âmbito do governo federal, com a edição da Emenda Constitucional 95, o aumento real de quase $3 \%$ ao ano com despesa de pessoal requer que sejam cortados recursos em outras áreas, também com impacto direto na disponibilização de serviços à população. (BANCO MUNDIAL, 2019, p. 6)

Essas informações são completadas com os dados trazidos no Sumário Executivo pertinente ao referido relatório recentemente lançado em 09 de outubro de $2019^{53}$, no qual fica explicitado o elevado comprometimento do PIB com despesas de pessoal, notadamente no âmbito da União, bem como a trajetória explosiva das despesas com pessoal, em que muitos

${ }^{51}$ Conceito tomado nos estritos termos da Lei Complementar $\mathrm{n}^{\circ}$ 101, de 04 de maio de 2000 (Lei de Responsabilidade Fiscal), consoante melhor delineado no Capítulo 2 desta tese.

52 BANCO MUNDIAL, Gestão de Pessoas e Folha de Pagamento no Setor Público Brasileiro: O que os dados dizem?, 2019.

Disponível em: http://documents.worldbank.org/curated/en/449951570645821631/pdf/Gest\%C3\%A3o-dePessoas-e-Folha-de-Pagamentos-no-Setor-P\%C3\%BAblico-Brasileiro-o-Que-Os-Dados-Dizem.pdf

${ }^{53}$ BANCO MUNDIAL. Sumário Executivo - Gestão de Pessoas e Folha de Pagamento no Setor Público Brasileiro: O que os dados dizem?. 2019.

Disponível em: http://documents.worldbank.org/curated/en/846691570645552393/pdf/Sum\%C3\%A1rioExecutivo.pdf 
já declararam calamidade financeira - "sete até o início de 2019", conforme passagem supracitada -, e com a perspectiva de agravamento desse quadro insustentável:

O Estado brasileiro gasta cerca de $10 \%$ do PIB com o pagamento de salários e vencimentos de servidores públicos ativos (2018). Segundo a Secretaria do Tesouro Nacional, somando-se despesas dos regimes próprios de previdência, são gastos aproximadamente $15 \%$ do PIB com o pagamento de servidores ativos e inativos. (BANCO MUNDIAL, 2019, p. 5)

Vale dizer, parcela considerável dos recursos disponíveis já vai para o pagamento dessas despesas, as quais estão em descontrolado caminho de crescimento. Esse preocupante quadro e os excessos por ele demonstrados ficam visíveis quando comparados os gastos com pessoal de países com características similares às nossas, como é o caso dos vizinhos da América Latina, o que não passou despercebido pelo supracitado relatório do Banco Mundial:

Em termos comparativos, o gasto do setor público brasileiro com folha de pagamentos é alto para os padrões internacionais. O gasto de pessoal é elevado em relação ao número de servidores públicos como proporção do emprego assalariado, cerca de $18 \%$. A relação entre o número de funcionários públicos e a população no Brasil $(5,6 \%)$ é mais alta do que a média latino-americana $(4,4 \%)$, mas inferior a países da OCDE $(9,5 \%)$, por exemplo (BANCO MUNDIAL, 2019, p. 5).

E se a perspectiva já é preocupante em relação à União, no que tange aos estados, como demonstram o número cada vez mais crescente de entes da Federação que não conseguem adimplir com o pagamento regular da folha de servidores, o momento efetivamente beira à calamidade, requerendo urgente correção de rumos.

Assim delineou o Banco Mundial a situação fiscal dos estados com base nos números colhidos pela instituição:

A situação nos estados brasileiros é ainda mais crítica, dado que eles fornecem serviços que são intensivos em pessoal, como educação, saúde e segurança pública, e muitos tem declarado calamidade financeira. $\mathrm{O}$ atraso no pagamento de salários, decorrente da falta de capacidade financeira, afeta diretamente a qualidade dos serviços públicos disponibilizados.

O desafio é enorme e, se nenhuma medida for adotada, a tendência é que mais estados declarem calamidade financeira nos próximos anos. (BANCO MUNDIAL, 2019, p. 5)

Dessa maneira, o deficit público, que era para ser exceção só é justificável em situações extraordinárias dentro de uma gestão fiscal responsável, norteada pelo equilíbrio entre receitas e despesas, passa a ser constante - e superá-lo parece ser uma pálida esperança quase além do horizonte visível.

Assim, corrobora-se com o vaticínio do Banco Mundial, pois, "no que tange à União, 
o 'novo normal' se tornou orçamentos deficitários - realidade que se repete desde 2016 -, na maioria dos casos redundando em um endividamento anual superior a centenas de bilhões de reais" (BANCO MUNDIAL, 2019, p. 5).

Outrossim, em 2020, como sói haveria de ser, teremos a repetição desse quadro, conforme explicitado na tabela seguinte (Tab. 01), extraída da apresentação do Projeto de Lei Orçamentária Anual 2020 (PLOA 2020), realizada pelo Ministério da Economia ${ }^{54}$ :

\section{Meta Fiscal - Resultado Primário do Setor Público}

\begin{tabular}{|c|c|c|c|c|c|c|c|c|}
\hline \multirow{2}{*}{ Discriminação } & \multicolumn{2}{|c|}{ LDO 2019} & \multicolumn{2}{|c|}{2020} & \multicolumn{2}{|c|}{2021} & \multicolumn{2}{|c|}{2022} \\
\hline & RS & $\%$ PIB & $\mathrm{RS}$ & $\%$ PIB & $\mathrm{RS}$ & $\%$ PIB & RS & $\%$ PIB \\
\hline Resultado Primário do Setor Público & $(132,0)$ & $(1,8)$ & $(118,9)$ & $(1,6)$ & $(65,3)$ & $(0,8)$ & $(30,3$ & $(0,3)$ \\
\hline Governo Central & $(139,0)$ & $(1,9)$ & $(124,1)$ & $(1,6)$ & $(68,5)$ & $(0,8)$ & $(31,4$ & $(0,4)$ \\
\hline Empresas Estatais Federais & $(3,5)$ & $(0,0)$ & $(3,8)$ & $(0,1)$ & $(4,0)$ & $(0,0)$ & 14,2 & $(0,0)$ \\
\hline Estados e Municípios & 10,5 & 0,1 & 9,0 & 0,1 & 7,3 & 0,1 & 5,3 & 0,1 \\
\hline
\end{tabular}

Fonte: SOF/FAZENDA/ME - LDO 2019 e Anexo de Metas Fiscais do Projeto de Lei de Diretrizes Orçamentárias de 2020

Em linha com essa perspectiva, conviveremos com orçamentos deficitários da União até 2022 - o qual já está basicamente contratado daqui até lá - sendo esse até mesmo um cenário otimista, dados os inúmeros "cisnes negros" 55 que poderão impactar a economia nacional, externos ou internos, no médio e no longo prazos.

E assim o é, em grande parte, pelo acentuado crescimento das despesas obrigatórias,

\footnotetext{
${ }^{54}$ Disponível em:

http://www.economia.gov.br/central-de-conteudos/apresentacoes/2019/2019-08-30_ploa_2020.pdf

55 Expressão cunhada pelo ensaísta e pesquisador Nassim Taleb para designar eventos raros e imprevisíveis ex ante, com grande impacto econômico. Para aprofundamento: TALEB, Nassim Nicholas. A lógica do cisne negro: o impacto do altamente improvável. Tradutor: Marcelo Schild. Rio de Janeiro: Best Seller, 2015.
} 
conforme explicitado pelo Ministério da Economia na sequência da citada apresentação do Projeto de Lei Orçamentária Anual 2020 (Gráf. 01) ${ }^{56}$ :

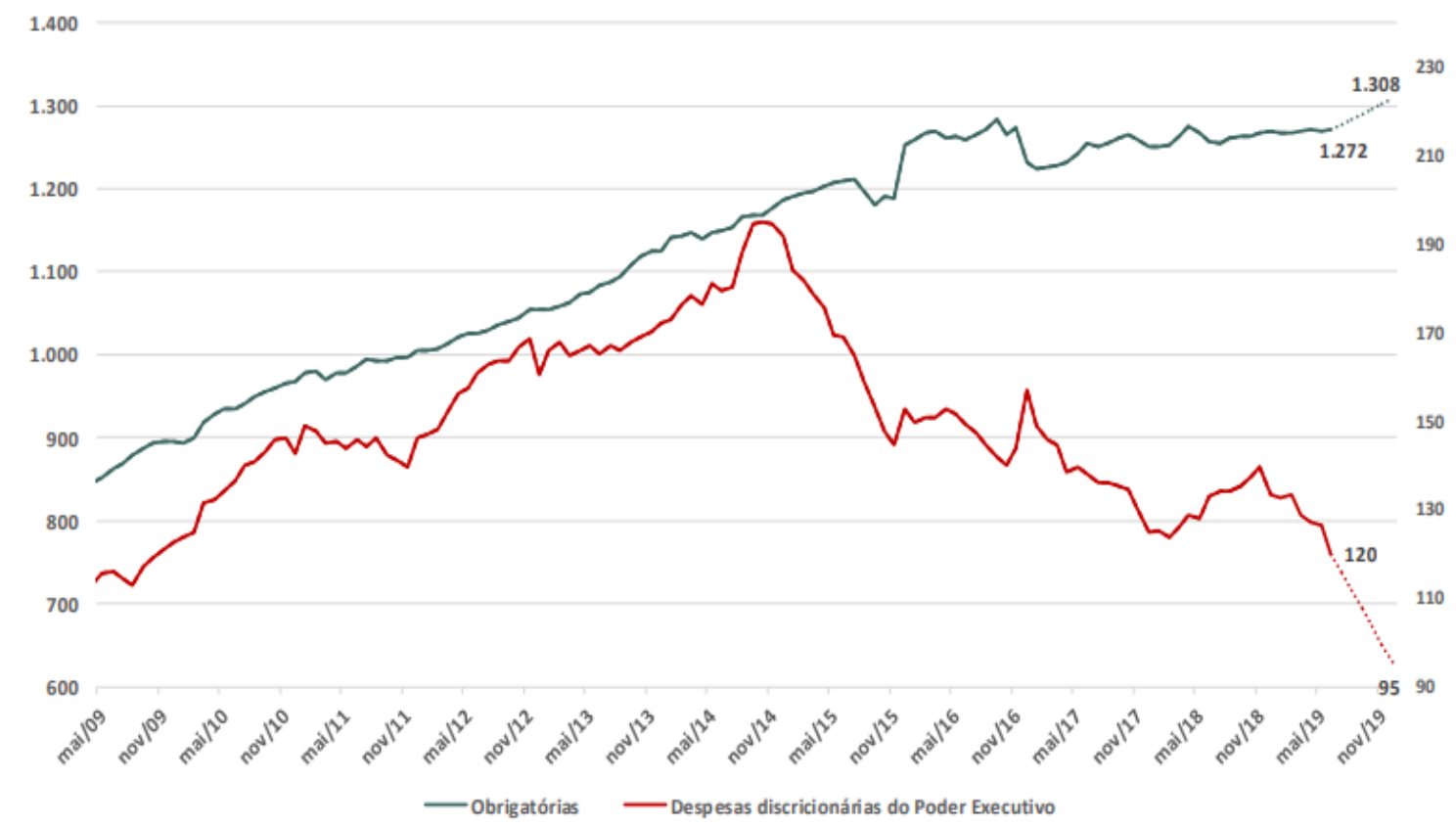

À evidência, esse quadro redunda em uma constante e elevada necessidade insustentável de financiamento do setor público, a qual é projetada na ordem de R $\$ 124,1$ bilhões para o ano de 2020, consoante o PLOA 2020.

Ocorre que esse círculo vicioso de deficits crescentes e despesas em constante expansão, com as suas inexoráveis consequências para a economia, torna ainda mais improvável a implementação de arrecadação, em flagrante choque com o princípio de prevenção de riscos fiscais insculpido no art. $1^{\circ}, \S 1^{\circ}$, da Lei de Responsabilidade Fiscal.

\begin{abstract}
$\S 1^{\mathrm{o}}$ A responsabilidade na gestão fiscal pressupõe a ação planejada e transparente, em que se previnem riscos e corrigem desvios capazes de afetar o equilíbrio das contas públicas, mediante o cumprimento de metas de resultados entre receitas e despesas e a obediência a limites e condições no que tange a renúncia de receita, geração de despesas com pessoal, da seguridade social e outras, dívidas consolidada e mobiliária, operações de crédito, inclusive por antecipação de receita, concessão de garantia e inscrição em Restos a Pagar.
\end{abstract}

Mais uma vez, o quadro de descontrole resta demonstrado em dados disponibilizados

\footnotetext{
${ }^{56}$ Gráf. 01 - Evolução da Composição da Despesa Primária do Governo Federal: Despesas do Governo Central (Acum.12 meses), em bilhões a preços de 2019; Fonte: Resultado do Tesouro Nacional/Ministério da Economia;

Disponível em: http://www.economia.gov.br/central-de-conteudos/apresentacoes/2019/2019-0830_ploa_2020.pdf
} 
pelo próprio Governo Federal, por intermédio de seu Ministério da Economia, entabulados na planilha que segue (Tab. 02) ${ }^{57}$ :

\section{Necessidade de Financiamento do Governo Central}

\begin{tabular}{|c|c|c|c|c|c|c|c|c|}
\hline \multirow{2}{*}{ Discriminação } & \multicolumn{2}{|c|}{2018 - Realizado } & \multicolumn{2}{|c|}{2019 - PLOA } & \multicolumn{2}{|c|}{$2019-3^{\mathrm{a}}$ Aval. } & \multicolumn{2}{|c|}{2020 - PLOA } \\
\hline & R\$ Bilhões & $\%$ PIB & R\$ Bilhões & $\%$ PIB & R\$ Bilhões & $\%$ PIB & R\$ Bilhões & $\%$ PIB \\
\hline I. RECEITA TOTAL & $1.484,2$ & 21,6 & $1.574,9$ & 21,2 & $1.540,5$ & 21,5 & $1.644,5$ & 21,6 \\
\hline II. TRANSFERÊNCIAS POR REPARTIÇÃO DE RECEITA & 256,7 & 3,7 & 275,2 & 3,7 & 276,2 & 3,9 & 289,0 & 3,8 \\
\hline III. RECEITA LÍQUIDA (I - II) & $1.227,5$ & 17,9 & $1.299,7$ & 17,5 & $1.264,4$ & 17,7 & $1.355,6$ & 17,8 \\
\hline IV. DESPESAS & $1.351,8$ & 19,7 & $1.438,7$ & 19,3 & $1.403,4$ & 19,6 & $1.479,7$ & 19,4 \\
\hline V. FUNDO SOBERANO DO BRASIL/PRECATÓRIOS FEDERAIS & 4,0 & 0,1 & & & & & & \\
\hline VI. PRIMÁRIO GOVERNO CENTRAL (III - IV + V) & $(120,2)$ & $(1,7)$ & $(139,0)$ & $(1,9)$ & $(139,0)$ & $(1,9)$ & $(124,1)$ & $(1,6)$ \\
\hline $\begin{array}{l}\text { VI.1. Resultado do Tesouro e do Banco Central } \\
\text { VI.2. Resultado da Previdência Social (RGPS) }\end{array}$ & $\begin{array}{r}75,0 \\
(195,2)\end{array}$ & $\begin{array}{r}1,1 \\
(2,8)\end{array}$ & $\begin{array}{r}79,0 \\
(218,0)\end{array}$ & $\begin{array}{c}1,1 \\
(2,9)\end{array}$ & $\begin{array}{r}76,9 \\
(215,9)\end{array}$ & $\begin{array}{c}1,1 \\
(3,0)\end{array}$ & $\begin{array}{c}120,1 \\
(244,2)\end{array}$ & $\begin{array}{c}1,6 \\
(3,2)\end{array}$ \\
\hline VII. DISCREPÂNCIA ESTATÍSTICA/ AJUSTE METODOLÓGICO & 4,1 & 0,1 & 0,00 & 0,00 & 0,00 & 0,00 & 0,00 & 0,00 \\
\hline VIII. PRIMÁRIO ABAIXO DA LINHA (III - IV + V + VII) & $(116,2)$ & $(1,7)$ & $(139,0)$ & $(1,9)$ & $(139,0)$ & $(1,9)$ & $(124,1)$ & $(1,6)$ \\
\hline IX. META OFS & $(159,0)$ & $(2,3)$ & $(139,0)$ & $(1,9)$ & $(139,0)$ & $(1,9)$ & $(124,1)$ & $(1,6)$ \\
\hline
\end{tabular}

Voltando os olhos para os estados da Federação, observa-se nitidamente esse quadro de descontrole dos gastos públicos ao verificarmos a evolução das despesas com pessoal desses entes, entre os anos de 2011 e 2018 , período no qual as despesas de pessoal dos estados tiveram um incremento médio da ordem de 39,36\%, sem computar as deduções previstas na Lei de Responsabilidade Fiscal - cuja caótica aplicação é um dos gargalos da efetiva implementação dos princípios da responsabilidade fiscal, consoante item 1.3 deste Capítulo.

No caso do Rio de Janeiro, por exemplo, o implemento nesse período foi superior a $100 \%$ (cem por cento), conforme gráfico (Graf. 02) ( $^{58}$ abaixo, no qual resta demonstrado o patamar de comprometimento das receitas correntes líquidas extraído do Boletim de Finanças

\footnotetext{
57 Tab. 01 - Necessidade de Financiamento do Governo Central. Fonte: SOF/FAZENDA/ME.

Disponível em: http://www.economia.gov.br/central-de-conteudos/apresentacoes/2019/2019-0830 ploa_2020.pdf

${ }^{58}$ Gráf. 02 - Crescimento real da despesa bruta com pessoal entre 2011 e 2018

Dados em: \%

Despesa empenhada

Deflator: IPCA médio de 2018

Elaboração própria

Fonte: Programa de Reestruturação e Ajuste Fiscal/Tesouro Nacional
} 
dos Entes Subnacionais 2019, documento elaborado pela Secretaria do Tesouro Nacional ${ }^{59}$ :

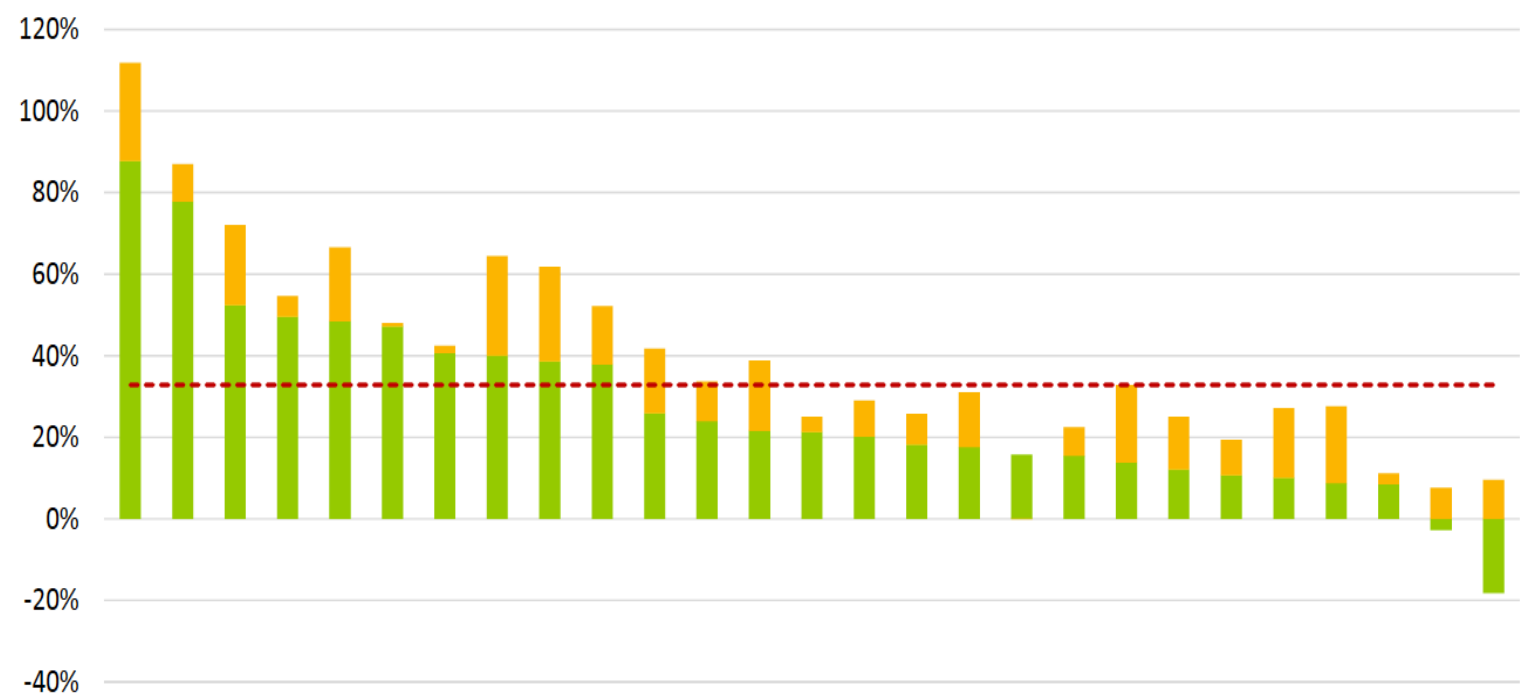

RJ MA MS MG TO PI RR MT AC RN GO PA PR AP SE AM AL RO PB RS BA CE SC DF PE ES SP

Ativos Inativos --- MEDIANA $=32,81 \%$

Fonte: Programa de Reestruturação e Ajuste Fiscal/Tesouro Nacional

Destaque-se a leitura da própria Secretaria do Tesouro Nacional da realidade traduzida no gráfico acima:

O quadro dos últimos sete anos mostra crescimento real de 39,36\% das despesas com pessoal, em média. As despesas apresentadas nessa análise são brutas, ou seja, sem as deduções previstas na LRF.

$\mathrm{O}$ crescimento real apresentado no gráfico $18^{60}$ ilustra que o quadro geral foi de expansão dos gastos tanto dos ativos quanto dos inativos, ainda que alguns Estados apresentassem crescimento mais modesto que outros. Já a distribuição dos gastos entre ativos e inativos apresenta certa discrepância. Alguns Estados, como Rio de Janeiro, Maranhão, Mato Grosso do Sul e Minas Gerais, aumentaram suas despesas principalmente com ativos. Já Estados como Espírito Santo e São Paulo tiveram crescimento negativo de gastos com ativos, em parte pela contenção dessa despesa, com crescimento inferior ao da inflação. No entanto, houve crescimento real das despesas com inativos.

A realidade para a maioria dos estados brasileiros é de acentuado crescimento das despesas com pessoal, culminando com posterior descasamento com as receitas que estarão disponíveis para arcar com estes gastos.

59 Secretaria do Tesouro Nacional (STN). Boletim de Finanças dos Entes Subnacionais. Brasília: 2019. Disponível em: www.economia.gov.br e http://sisweb.tesouro.gov.br/apex/cosis/thot/transparencia/arquivo/30407:981194:inline:9731352684720

${ }^{60}$ Gráfico 02 da presente tese. 


\subsection{O PAPEL DESEMPENHADO PELOS TRIBUNAIS DE CONTAS ESTADUAIS E MUNICIPAIS NESSE CONTEXTO ECONÔMICO}

A este quadro econômico caótico, chega-se com diversas pinceladas aleatórias. Entre umas das mais premente delas, tem-se a díspar forma de quantificação das despesas com pessoal em diversos entes da Federação, via de regra com o beneplácito dos respectivos tribunais de contas.

Vale dizer, o sistema de controle que deveria gerar segurança e sustentabilidade à responsabilidade fiscal, com a adequada prevenção de riscos, não foi capaz de prevenir nem conter a crise que havia muito apontava no horizonte.

Mais do que isso, em muitos casos, foi a engrenagem que possibilitou instalação e perpetuação da crise, à medida que participou de medidas de quantificação artificial das despesas com pessoal, geralmente com o propósito velado de afastar as suas sanções, tendo como efeito colateral a manutenção desse estado de coisas fiscalmente irresponsável.

Vale dizer, os Tribunais de Contas foram vetores de enfraquecimento dos mecanismos pensados pela Lei de Responsabilidade Fiscal para afastar a gestão de recursos públicos de modo fiscalmente irresponsável, notadamente ao mitigar a concretização de sanções em face do desrespeito à suas normas.

De fato, embora a Lei de Responsabilidade Fiscal centre-se na "ênfase dada pelo legislador à coibição do risco moral (moral hazard), até então uma constante no Brasil" (CAVALCANTI, 2001, p. 75) ${ }^{61}$ - sendo que esse risco moral (moral hazard) "significa dilapidar o patrimônio público de forma irresponsável, por saber que não existirá punição, ou que os cofres da União irão bancar o rombo por eles provocado" (CAVALCANTI, 2001, p. $74)^{62}$-, aquilo que se pretendeu afastar abstratamente na norma foi esvaziado por omissões e, em muitos casos, atos comissivos praticados pelos controladores.

Com esse proceder, o risco moral foi reforçado ao longo dos anos de aplicação da Lei de Responsabilidade Fiscal, em oposição ao quanto pretendido pelo legislador e pontuado pela doutrina desde o nascedouro da lei.

De maneira clara, é possível traçar um paralelo entre os estados em que a crise econômica mais ficou aguda nesses últimos anos e os que mais se afastaram dos cálculos efetuados pela Secretaria do Tesouro Nacional para essas mesmas despesas, conforme dados catalogados pelo consultor legislativo do Senado Federal, Carlos Alexandre Rocha, referentes

${ }^{61}$ CAVALCANTI, Márcio Novaes. Fundamentos da Lei de Responsabilidade Fiscal. São Paulo: Dialética, 2001. ${ }^{62}$ Ob. cit. 
ao ano de 2015 e expostos no artigo A Despesa Total com Pessoal na Ótica da STN e dos Tribunais de Contas Estaduais e Municipais ${ }^{63}$ (Táb. 03) ${ }^{64}$ :

\begin{tabular}{|c|c|c|c|c|c|c|c|}
\hline UF & $\begin{array}{c}\mathbf{R C L} \\
(\mathrm{em} \text { mil RS) }\end{array}$ & $\begin{array}{l}\text { STN-RGF } \\
\text { (em p.p.) }\end{array}$ & $\begin{array}{c}\text { VALOR } \\
\text { (em mil R\$) }\end{array}$ & UF & $\begin{array}{c}\text { RCL } \\
(\mathrm{em} \text { mil R\$)\# }\end{array}$ & $\begin{array}{l}\text { STN-RGF } \\
\text { (em p.p.) }\end{array}$ & $\begin{array}{c}\text { VALOR } \\
\text { (em mil R\$) }\end{array}$ \\
\hline RJ & 51.224 .317 & 21,07 & $10.792 .963,59$ & RO & 5.824 .977 & 1,76 & $102.519,60$ \\
\hline MG & 51.643 .236 & 20,67 & $10.674 .656,88$ & $\mathrm{RR}$ & 2.824 .663 & 2,59 & $73.158,77$ \\
\hline RS & 30.139 .172 & 12,51 & $3.770 .410,42$ & MT & 11.636 .649 & 0,62 & $72.147,22$ \\
\hline PR & 31.807 .637 & 10,74 & $3.416 .140,21$ & $\mathrm{AC}$ & 3.949 .108 & $-0,18$ & $-7.108,39$ \\
\hline $\mathrm{DF}$ & 18.461 .481 & 14,89 & $2.748 .914,52$ & $\mathrm{RN}$ & 7.996 .957 & $-0,40$ & $-31.987,83$ \\
\hline GO & 17.361 .933 & 13,43 & $2.331 .707,60$ & $\mathrm{SC}$ & 19.409 .871 & $-0,70$ & $-135.869,10$ \\
\hline MS & 8.126 .449 & 27,66 & $2.247 .775,79$ & ES & 11.951 .595 & $-1,41$ & $-168.517,49$ \\
\hline SF & 6.353 .339 & 7,37 & $468.241,08$ & $\mathrm{CE}$ & 15.176 .417 & $-1,35$ & $-204.881,63$ \\
\hline $\mathrm{PA}$ & 16.789 .902 & 2,71 & $455.006,34$ & SP & 140.398 .953 & $-0,15$ & $-210.598,43$ \\
\hline PI & 6.600 .087 & 5,51 & $363.664,79$ & $\mathrm{AM}$ & 10.998 .994 & $-2,32$ & $-255.176,66$ \\
\hline $\mathrm{AL}$ & 6.311 .578 & 5,48 & $345.874,47$ & MA & 10.703 .906 & $-2,73$ & $-292.216,63$ \\
\hline $\mathrm{BA}$ & 27.207 .611 & 1,0 & $280.238,39$ & TO & 6.304 .772 & $-5,03$ & $-317.130,03$ \\
\hline $\mathrm{AP}$ & 3.875 .537 & 5,94 & $230.206,90$ & PE & 19.648 .437 & $-2,84$ & $-558.015,61$ \\
\hline PB & 7.973 .372 & 2,58 & $205.713,00$ & MÉDIA & 20.396.331 & 5,16 & $1.348 .068,07$ \\
\hline
\end{tabular}

Táb. 03 - Diferença entre as Despesas com Pessoal Informadas e Calculadas

De posse desses dados, o citado consultor do Senado Federal ${ }^{65}$ aponta para a inexorável direção da associação entre a retirada de despesas pela metodologia dos tribunais de contas e a crise vivenciada pelos entes em que esse fato ocorreu em maior monta:

Os entes que ora aparecem em qualquer relação sobre os mais afetados pela presente crise econômica estão entre os que mais divergiram da STN no cálculo da despesa total com pessoal. Isso não é mera coincidência (ROCHA, 2018, p. $13)$.

Outrossim, a própria Secretaria do Tesouro Nacional já trabalha com essa hipótese,

${ }^{63}$ ROCHA C. A. A. A Despesa Total com Pessoal na Ótica da STN e dos Tribunais de Contas Estaduais e Municipais. Brasília: Núcleo de Estudos e Pesquisas/CONLEG/Senado, maio/2018 (Boletim Legislativo $n^{\circ} 71$ ). Disponível em: www.senado.leg.br/estudos. Acesso em 07 de maio de 2018.

${ }^{64}$ Táb. 03: Diferença entre as Despesas com Pessoal Informadas e Calculadas. Fonte: STN; calculado pelo autor Carlos Alexandre Rocha.

Notas originais: (\#) valor em 31/12/2015; (*) expressa em termos de participação na receita corrente líquida. ${ }^{65} \mathrm{Ob}$. Cit. 
tendo destacado esse fato no Boletim de Finanças dos Entes Subnacionais (2019) ${ }^{66}$ :

Assim, há evidências de que a metodologia de cálculo da despesa com pessoal aplicada por parte dos Tribunais de Contas locais permitiu que os Estados direcionassem boa parte do orçamento para as despesas com pessoal.

Em alguns casos, provavelmente, esse é um dos principais motivos da crise fiscal observada atualmente. (grifos nossos) (SECRETARIA DO TESOURO NACIONAL, 2019, p. 34)

Vale dizer, na esteira dos dados da Secretaria do Tesouro Nacional, o sistema de controle de despesas com pessoal nos entes subnacionais é a provável principal causa de descontrole dessas mesmas despesas, cristalizada na crise fiscal generalizada em diversos entes.

Nessa mesma linha de pensamento, vale trazer à baila o perfeito diagnóstico dessa nuance do sistema de controle procedido no artigo "Tribunais de Contas na Interpretação da Lei de Responsabilidade Fiscal" ${ }^{67}$ :

Desde a introdução da Lei Complementar $n^{\circ}$ 101/2000, chamada de Lei de Responsabilidade Fiscal (LRF), em 2000, têm sido constatadas várias mudanças institucionais dadas pela interpretação da legislação pelos Tribunais de Contas (TCs), ocasionando uma espécie de mutação genética. Embora isso não gere um problema de compliance para governadores e prefeitos no curto prazo, porque cumprem as normas dos tribunais de contas, pode inviabilizar a gestão financeira no médio prazo e certamente reduzir a uniformidade da regulação fiscal na Federação.

Consequentemente, o comportamento de governos estaduais e municipais, assim como comissões de orçamento e finanças das casas legislativas, não é o mesmo entre os diversos estados. Tal fato tem contribuído para a redução da capacidade da regra fiscal de controlar o gasto excessivo e sobreendividamento dos governos. (grifos nossos) (NUNES, et al., 2019, p. 1/2)

Obviamente, tem-se aqui evidente e cristalino indicador de falha sistêmica desse conjunto normativo que acaba por produzir o oposto do quanto pretendido pelo ordenamento jurídico que o instituiu.

Ocorre que, dada a gravidade da crise fiscal em determinados estados, eles já começam a se ver obrigados a reconhecer o equívoco dessa metodologia de quantificação das despesas com pessoal, conforme destacado por Carlos Alexandre Rocha ${ }^{68}$ :

\footnotetext{
${ }^{66}$ Secretaria do Tesouro Nacional (STN). Boletim de Finanças dos Entes Subnacionais. Brasília: 2019. Disponível em: www.economia.gov.br e

http://sisweb.tesouro.gov.br/apex/cosis/thot/transparencia/arquivo/30407:981194:inline:9731352684720

${ }^{67}$ NUNES, Selene Peres; MARCELINO, Gileno Fernandez e SILVA, César Augusto Tibúrcio. Os Tribunais de Contas na interpretação da Lei de Responsabilidade Fiscal. Revista de Contabilidade e Organizações, Vol. 13:e145151 (2019). São Paulo: FEA-RP/USP, 2019. DOI: http://dx.doi.org/10.11606/issn.19826486.rco.2019.145151

${ }^{68}$ ROCHA C. A. A. A Despesa Total com Pessoal na Ótica da STN e dos Tribunais de Contas Estaduais e
} 
A recente adesão do estado do Rio de Janeiro ao Regime de Recuperação Fiscal (RRF) significa que seus indicadores fiscais foram recalculados segundo a fórmula propugnada pela STN. Ademais, há um esforço nessa mesma direção, ainda em fase de negociação, por parte do estado do Rio Grande do Sul. Caso este último seja confirmado, dois focos importantes de divergências metodológicas terão, premidos pelas circunstâncias, convergido para o padrão federal. Permanece em aberto como os demais entes se comportarão no futuro próximo (ROCHA, 2018, p. 13).

Obviamente, o sistema de controle de despesas com pessoal não pode se dar ao luxo de viver uma crise do tamanho das atualmente existentes nos estados do Rio de Janeiro e do Rio Grande do Sul - entre outros entes da Federação que flertaram com o precipício das contas públicas nos últimos anos - para, então, corrigir essa distorção do sistema, com todas as consequências negativas para o interesse público até o atingimento desse estado de coisas.

É imperioso para a higidez do sistema que haja um mecanismo institucional organizado que seja efetivamente capaz de retirar do convívio com as demais normas as que sejam com elas incoerentes, pois a sua funcionalidade pressupõe unidade no quanto seja por elas prescrito, inclusive no que tange ao atingimento de finalidades econômicas.

Novamente, cita-se Carlos Alexandre Rocha ${ }^{69}$ na identificação dos efeitos econômicos decorrentes da flexibilização dos limites de despesas previstos na Lei de Responsabilidade Fiscal, bem como o esvaziamento sancionatório da força das normas de responsabilidade fiscal na matéria:

A crise fiscal que vários estados enfrentam indica que os posicionamentos da STN sobre como as despesas com pessoal deveriam ser contabilizadas são os mais condizentes com os princípios de uma gestão fiscal responsável. A discussão sobre a natureza contábil ou financeira dos conceitos contidos na LRF acabou relegando a um plano menor a sua dimensão econômica. Considerandose também a crise da década de 1990, deveria estar claro que os limites fixados expressavam as lições supostamente aprendidas com o alto grau de rigidez dos gastos públicos, em geral, e o nível elevado de comprometimento das receitas públicas com as despesas com pessoal, em particular, gerando pressões inflacionárias avassaladoras (ROCHA, 2018, p. 14).

E segue o autor destacando os problemas decorrentes das exclusões casuísticas e enfraquecedoras da responsabilidade fiscal Brasil afora:

A LRF representava o coroamento de um longo processo de ajuste econômico, e os seus indicadores destinavam-se a assegurar que os descontroles do passado não voltariam a acontecer. Nesse sentido, as exclusões ad hoc de receitas e despesas resultaram no empobrecimento dos

Municipais. Brasília: Núcleo de Estudos e Pesquisas/CONLEG/Senado, maio/2018 (Boletim Legislativo n 71). Disponível em: www.senado.leg.br/estudos. Acesso em 07 de maio de 2018.

${ }^{69}$ Ob. cit. 
indicadores concebidos e, consequentemente, na não antecipação dos problemas fiscais correspondentes. Na ausência dessas exclusões, as sanções contidas no art. 23 da LRF poderiam ter minorado a crise em curso ao coibir, em um contexto menos traumático, a realização de concursos públicos, a concessão de reajustes aos servidores e a contratação de novos empréstimos, entre outras. (ROCHA, 2018, p. 14)

À evidência, a previsão abstrata da norma pressupõe a capacidade sistêmica de sua concretização de modo a atingir as finalidades planejadas. A cada nova camada da Lei de Responsabilidade Fiscal que é mitigada pela atuação daqueles que deveriam dar-lhe plena aplicabilidade, mais distante estará a almejada sustentabilidade fiscal, com o imprescindível equilíbrio entre receitas e despesas, ora pela incorreta detecção dos riscos fiscais, ora pelo afastamento do consequente da norma quando concretizadas determinadas condutas abstratamente previstas.

Nessa esteira, tem-se um disfuncional controle de despesas com pessoal.

\subsection{DAS FALHAS SISTEMICAS DO REGIME DE CONTROLE DE DESPESAS COM PESSOAL}

Outrossim, além do contexto econômico e da crise das finanças públicas que ora vivemos - aspectos necessários para a integral compreensão do regramento jurídico da atividade financeira -, somem-se os diversos indícios de ineficiência em múltiplos pontos do Sistema de Finanças Públicas, tal qual ele é atualmente aplicado no Brasil, com especial ênfase no controle das despesas públicas, para que se torne urgente refazer as fundações desse edifício normativo, a começar por fazer incidir sobre todo ele os sobreprincípios norteadores da atividade financeira.

A título de exemplo dessa disfuncionalidade do sistema, entre vários outros, toma-se como ponto mais visível dessa distonia a pluralidade de tratamentos dados pelos tribunais de contas do país à Lei de Responsabilidade Fiscal, aqui tomada não mais sob o ponto de vista das consequências econômicas descritas no item 1.2 supra, mas, sim, quanto à higidez do sistema jurídico de controle de despesas com pessoal.

Tome-se, a título de exemplo, a interpretação dada pelo Tribunal de Contas de Santa Catarina, a qual culminou por incluir uma nova exclusão de gastos a serem computados nos limites das despesas com pessoal previstas na Lei de Responsabilidade Fiscal:

Tribunal de Contas do Estado de Santa Catarina. Prejulgado:

A exclusão dos valores resultantes da retenção do imposto de renda dos servidores públicos da apuração da Despesa Total com Pessoal de que trata o art. 18 da Lei Complementar $n^{\circ} 101 / 00$, não expressamente prevista no $\S 1^{\circ}$ do art. 
19 daquela Lei Complementar ou nos modelos de relatórios de gestão fiscal estabelecidos pelo órgão central de contabilidade da União, vinculado à Secretaria do Tesouro Nacional, pode ser admitida, em caráter excepcional, considerando que os conceitos de receita e despesa que integram a Lei de Responsabilidade Fiscal possuem caráter eminentemente financeiro e não propriamente orçamentário e contábil, e desde que haja entendimento convergente dos Poderes e órgãos mencionados no art. 20 do referido diploma legal, alertando-se para eventuais divergências quando da consolidação das contas nacionais a cargo da União (art. 51 da LRF). (TCE/SC. Processo: CON02/11013536. Parecer: COG-349/04 com acréscimos do Voto do Relator, Decisão: 3721/2004, Origem: Procuradoria-Geral de Justiça (Ministério Público), Relator: Auditor Clóvis Mattos Balsini, Data da Sessão: 22/11/2004, Data do Diário Oficial: 24/02/2005.)

Casos como esse multiplicam-se ao longo de todo o país, consoante apontado no Capítulo VI desta tese, invariavelmente com efeitos abstratos e erga omnes dentro da área de abrangência do respectivo tribunal de contas, que age como se estivesse autorizado pelo sistema para legislar, notadamente em matéria de normas gerais de Direito Financeiro, cuja competência é da União.

A olhos vistos, a diversidade de interpretações varia desde a própria aferição do quantitativo de gastos com pessoal em determinado período, até as consequências da ultrapassagem dos limites de gastos com pessoal e as medidas a serem adotadas a partir de cada patamar atingido, tanto de tribunal para tribunal quanto ao longo do tempo dentro de uma mesma jurisdição de controle externo.

A essa profusão de interpretações, some-se o fato de que eles permanecem vigentes no sistema, sem que haja um mecanismo eficaz de harmonização, com o agravante de que na maioria dos casos elas se cristalizam em atos normativos vinculantes para os administradores públicos que estejam sob a jurisdição do órgão de controle do qual emanou a decisão.

Com a precisa demonstração do problema, esse foi objeto de levantamento e entabulação no Boletim de Finanças dos Entes Subnacionais 2019, com dados pertinentes a 2018, elaborado pela Secretaria do Tesouro Nacional (STN), conforme tabela 04 (Táb. 04). ${ }^{70}$

No referido documento, o Tesouro Nacional traça um paralelo entre os relatórios de gestão fiscal (RGF) apresentados aos respectivos tribunais de contas e o quanto dimensionado pelo Ministério da Economia no âmbito do Programa de Reestruturação e Ajuste Fiscal (PAF), com flagrante distorção na grande maioria dos dados analisados em cotejo com essas duas fontes:

\footnotetext{
${ }^{70}$ Secretaria do Tesouro Nacional (STN). Boletim de Finanças dos Entes Subnacionais. Brasília: 2019, p. 31. Disponível em: www.economia.gov.br e http:/sisweb.tesouro.gov.br/apex/cosis/thot/transparencia/arquivo/30407:981194:inline:9731352684720
} 
Táb. 04 - Comparativo de despesa com pessoal 2018 - todos os poderes - RGF X PAF

\begin{tabular}{|c|c|c|}
\hline UF & Despesa Pessoal/RCL PAF & Despesa Pessoal/RCL RGF \\
\hline AC & $65,86 \%$ & $56,81 \%$ \\
\hline AL & $58,96 \%$ & $54,62 \%$ \\
\hline AM & $54,37 \%$ & $55,84 \%$ \\
\hline AP & $56,18 \%$ & $49,32 \%$ \\
\hline BA & $59,42 \%$ & $56,08 \%$ \\
\hline CE & $56,28 \%$ & $51,74 \%$ \\
\hline DF & $50,27 \%$ & $45,80 \%$ \\
\hline ES & $52,30 \%$ & $50,67 \%$ \\
\hline GO & $65,52 \%$ & $54,67 \%$ \\
\hline MA & $60,22 \%$ & $56,51 \%$ \\
\hline MG & $78,13 \%$ & $75,86 \%$ \\
\hline MS & $63,55 \%$ & $53,75 \%$ \\
\hline MT & $71,12 \%$ & $67,48 \%$ \\
\hline PA & $57,18 \%$ & $56,27 \%$ \\
\hline PB & $62,78 \%$ & $60,25 \%$ \\
\hline PE & $58,45 \%$ & $56,87 \%$ \\
\hline PI & $65,19 \%$ & $56,79 \%$ \\
\hline PR & $59,32 \%$ & $53,05 \%$ \\
\hline RJ & $62,69 \%$ & $46,04 \%$ \\
\hline RN & $66,44 \%$ & $57,57 \%$ \\
\hline RO & $53,44 \%$ & $51,23 \%$ \\
\hline RR & $57,92 \%$ & $55,62 \%$ \\
\hline RS & $66,87 \%$ & $54,44 \%$ \\
\hline SC & $59,25 \%$ & $58,42 \%$ \\
\hline SE & $59,07 \%$ & $57,36 \%$ \\
\hline SP & $54,22 \%$ & $51,30 \%$ \\
\hline TO & $79,22 \%$ & $68,14 \%$ \\
\hline Mediana & $59,32 \%$ & $55,84 \%$ \\
\hline
\end{tabular}

Fontes: Programa de Reestruturação e Ajuste Fiscal/Tesouro Nacional e Siconfi/Tesouro

Nacional $^{71}$

Como se observa na tabela supra, no ano de 2018, em todos os estados da Federação houve discrepância entre o valor apurado pela Secretaria do Tesouro Nacional - por intermédio do PAF - e o quanto aferido pelo respectivo Tribunal de Contas, consoante Relatórios de Gestão Fiscal (RGF) divulgados.

Ademais, à exceção do estado do Amazonas, em todos os demais a situação de

71 Táb. 04 - Comparativo de despesa com pessoal 2018 - todos os poderes - RGF X PAF. Dados em: \%. Despesa por competência. Elaborada pela Secretaria do Tesouro Nacional. Fontes: Programa de Reestruturação e Ajuste Fiscal/Tesouro Nacional e Siconfi/Tesouro Nacional. 
comprometimento das despesas com pessoal em face da receita corrente líquida é mais grave do que o quanto pintado para o sistema de controle imediato - valendo destacar os casos do AC, GO, MA, MS, PI, RJ, RN e RS, que estavam artificialmente abaixo do limite total de despesas com pessoal, quando efetivamente já o tinham ultrapassado, com discrepâncias tais como o estado do RJ que apontava estar abaixo até mesmo do limite de alerta.

Ao interpretar os dados dessa tabela, assim ficou registrada a atuação dos tribunais de contas nas palavras da Secretaria do Tesouro Nacional ${ }^{72}$ :

Minas Gerais, Mato Grosso, Paraíba e Tocantins ultrapassaram o limite. Entretanto, cabe destacar que Minas Gerais e Mato Grosso, já conscientes de sua delicada situação fiscal, passaram a contabilizar melhor a despesa com pessoal em 2018, mais alinhada com o MDF e o MCASP, fato que deve evitar tanto o agravamento como o surgimento de crises futuras (SECRETARIA DO TESOURO NACIONAL, 2019, p. 31).

De acordo com a LRF, os estados não devem exceder o limite de $60 \%$ da relação despesa com pessoal/receita corrente líquida. No entanto, em diversos casos, há diferença nas metodologias aplicadas pelos respectivos Tribunais de Contas para os cálculos da despesa com pessoal em relação àquela aplicada no PAF. Alguns estados, por exemplo, não consideram em suas despesas com pessoal algumas rubricas de despesas importantes, como as despesas com pensionistas, imposto de renda retido na fonte e as despesas com obrigações patronais.

Novamente, de modo a enraizar o generalizado quadro de mutilação da Lei de Responsabilidade fiscal pelos tribunais de contas, estado por estado, voltam-se os olhos para os dados contidos no Boletim de Finanças dos Entes Subnacionais (2019), consoante tabela (Táb. 05) ${ }^{73}$ :

\footnotetext{
${ }^{72}$ Ob. cit.

${ }^{73}$ Ob. cit., p. 32.
} 
Táb. 05 - Particularidades do cálculo de despesa líquida com pessoal realizado pelos estados

\begin{tabular}{|c|c|c|c|}
\hline UF & $\begin{array}{l}\text { Deduz valores } \\
\text { de benefício } \\
\text { previdenciários não } \\
\text { previstos no MDF? }\end{array}$ & $\begin{array}{c}\text { Exclui os } \\
\text { pensionistas } \\
\text { do cômputo da } \\
\text { despesa com } \\
\text { pessoal? }\end{array}$ & $\begin{array}{c}\text { Exclui valores de } \\
\text { IRRF da Despesa } \\
\text { Bruta? }\end{array}$ \\
\hline$A C$ & $\operatorname{sim}$ & não & não \\
\hline$A L$ & não & não & não \\
\hline AM & não & não & não \\
\hline AP & não & não & não \\
\hline BA & $\operatorname{sim}$ & não & $\operatorname{sim} *$ \\
\hline CE & $\operatorname{sim}$ & $\operatorname{sim}$ & não \\
\hline DF & $\operatorname{sim}$ & sim & não \\
\hline ES & não & não & não \\
\hline GO & $\operatorname{sim}$ & sim & sim \\
\hline MA & $\operatorname{sim}$ & não & não \\
\hline MG & $\operatorname{sim}$ & não & não \\
\hline MS & $\operatorname{sim}$ & não & não \\
\hline MT & $\operatorname{sim}$ & não & não \\
\hline PA & sim & não & não \\
\hline PB & $\operatorname{sim}$ & não & $\operatorname{sim}$ \\
\hline PE & $\operatorname{sim}$ & não & não \\
\hline PI & sim & não & não \\
\hline PR & $\operatorname{sim}$ & não & não \\
\hline RJ & $\operatorname{sim}$ & não & não \\
\hline RN & sim & não & não \\
\hline RO & não & não & não \\
\hline RR & não & não & não \\
\hline RS & sim & sim & sim \\
\hline sc & não & não & $\operatorname{sim} * *$ \\
\hline SE & não & não & não \\
\hline SP & $\operatorname{sim}$ & não & não \\
\hline TO & sim & não & não \\
\hline
\end{tabular}

*Somente o Tribunal de Justiça da Bahia

**Somente o Ministério Público de Santa Catarina

Elaboração: Secretaria do Tesouro Nacional

Fontes: Siconfi/Tesouro Nacional

Analisando os julgamentos inerentes a esse tema em diversos Tribunais de Contas do país, tem-se interpretações dos mais variados matizes, com inúmeros temperos locais acrescidos a uma lei que deveria ser de âmbito nacional - desde a exclusão do imposto de renda retido na fonte do cálculo de despesas com pessoal, passando por exclusão de gastos com pensionistas, até novas hipóteses de exceção à vedação de aumento de despesas quando ultrapassados os limites legal e prudencial da Lei de Responsabilidade Fiscal. 
Delineando à perfeição as mudanças de interpretação da LRF em 19 anos, traz-se à baila o minucioso trabalho de catalogação realizado por Selene Peres Peres Nunes, Gileno Fernandez Marcelino e César Augusto Tibúrcio Silva, plasmado no artigo "Os Tribunais de Contas na interpretação da Lei de Responsabilidade Fiscal"74, sintetizado na tabela elaborada pelos autores pertinente às alterações inerentes às despesas com pessoal:

Táb. 06 - Mudança de interpretação da LRF em 19 anos

\begin{tabular}{|c|c|c|c|}
\hline Tema & Questöes & Como é relaxada (R) ou intensificada (I) a regra? & Meio para interpretação ou coerção \\
\hline \multirow{10}{*}{$\begin{array}{l}\text { Limite: } \\
\text { Despesas com pessoal } \\
\text { Receita Corrente Liquida }\end{array}$} & Imposto de Renda Retido na Fonte & $\begin{array}{l}\text { Exclusão da Receita Corrente Liquida, juntamente coma } \\
\text { exclusão na Despesa com Pessoal (R) }\end{array}$ & Resoluçào do TC \\
\hline & Inativos & $\begin{array}{l}\text { Exclusào das Despesas com pessoal (R) } \\
\text { Deducào das Despesas com pessoal do aporte para } \\
\text { cobertura de déficit financeiro dos fundos de previdềncia } \\
\text { (nào admitido legalmente), simulando que é aporte atuarial } \\
\text { (admitido legalmente): "banho na Previdência" (R) }\end{array}$ & Julgamento de caso concreto \\
\hline & Pensionistas & Exclusão das Despesas com pessoal (R) & Resoluçào do TC \\
\hline & Distribuição de limites por Poder & Alteração dos limites: "condominio de limites"(R) & $\begin{array}{l}\text { Lei de Diretrizes Orçamentárias (LDO) ou } \\
\text { Resoluçào do TC }\end{array}$ \\
\hline & $\begin{array}{l}\text { Despesas com Pessoal relativas ao Programa de Saúde } \\
\text { na Familia }\end{array}$ & Exclusão das Despesas com pessoal (R) & $\begin{array}{l}\text { Resoluçào do TC ou julgamento de caso } \\
\text { concreto }\end{array}$ \\
\hline & $\begin{array}{l}\text { Espécies de despesas com caráter remuneratótio. Ex: } \\
\text { auxilio-livro }\end{array}$ & $\begin{array}{l}\text { Exclusão das Despesas com pessoal, simulando que são } \\
\text { espécies indenizatórias (R) }\end{array}$ & Julgamento de caso concreto ou nào atuação \\
\hline & $\begin{array}{l}\text { Realizacãa de despesas "fora" do serviço público, } \\
\text { inclusive com burla ao concurso público }\end{array}$ & $\begin{array}{l}\text { Exclusão das Despesas com pessoal: "burla de abrangência" } \\
\text { (R) }\end{array}$ & $\begin{array}{l}\text { Em alguns casos houve atuação do } \mathrm{TC} \text {, em } \\
\text { outros não }\end{array}$ \\
\hline & Royalties & Exclusão da Receita Corrente Liquida (I) & $\begin{array}{l}\text { Resolução do TC ou julgamento de caso } \\
\text { concreto }\end{array}$ \\
\hline & $\begin{array}{l}\text { Receitas vinculadas (transferências voluntárias, por } \\
\text { exemplo) }\end{array}$ & Exclusão(I) & $\begin{array}{l}\text { Resoluçào do TC ou julgamento de caso } \\
\text { concreto }\end{array}$ \\
\hline & $\begin{array}{l}\text { Concessão do direito de exploração da follha de } \\
\text { pagamentos }\end{array}$ & Exclusào (I) & . \\
\hline
\end{tabular}

\footnotetext{
${ }^{74}$ NUNES, Selene Peres; MARCELINO, Gileno Fernandez; e SILVA, César Augusto Tibúrcio. Os Tribunais de Contas na interpretação da Lei de Responsabilidade Fiscal Revista de Contabilidade e Organizações. São Paulo: FEA-RP/USP, 2019, Vol. 13, p. 6. DOI: http://dx.doi.org/10.11606/issn.1982-6486.rco.2019.145151
} 
Assim, no tema dos gastos com pessoal, salta aos olhos a miríade de interpretações dos mais diversos tribunais de contas, muitas vezes sem o aprofundamento teórico-científico necessário, além de não haver um mecanismo formal eficaz para harmonização dessas interpretações, que não são normalmente sequer levadas ao crivo do Poder Judiciário.

Com essa miscelânea de interpretações, era absolutamente natural que elas entrassem em choque com a interpretação da Secretaria do Tesouro Nacional, ensejando como efeito colateral indesejado a mitigação dos meios coercitivos necessários para que os limites de despesa com pessoal fossem efetivamente respeitados, além da situação caótica decorrente de uma aferição matemática, geradora de dois resultados divergentes e muitas vezes mutuamente excludentes, como estar ou não acima do limite total de despesas com pessoal.

Por óbvio, sem que haja um correto diagnóstico do problema, torna-se utópico imaginar que haverá um adequado endereçamento da sua solução.

De fato, urge revisitar o tema "relativo à eficácia das regras das limitações com despesas de pessoal que, não obstante as previsões legais constantes da LRF, continuam gradativamente a se expandir" (ABRAHAM, 2019, p. 72) ${ }^{75}$

Com esse desiderato, verificou-se em diversas oportunidades ao longo desta pesquisa - englobando inúmeros órgãos vinculados a uma variada gama de entes federativos - a apresentação de relatórios de gestão físcal discrepantes, embora atinentes a idêntico período (conforme pode ser observado na Tabela 03), em função do destinatário desses relatórios, em frontal ofensa à transparência fiscal, mormente no aspecto credibilidade.

Portanto, a referida conduta fere gravemente um dos pilares do Estado Democrático de Direito - cujo esteio de todo o poder é o povo, em conformidade com o art. $1^{\circ}$, parágrafo único da Constituição da República -, haja vista este calcar-se na transparência em geral e especificamente na transparência fiscal no âmbito financeiro, de modo a que sempre se preste contas ao titular do poder.

Assim, a estrita observância dos valores democráticos implica em destacada ênfase na transparência fiscal, na esteira das lições de Marcus Abraham ${ }^{76}$ :

Estas qualidades ou virtudes éticas de clareza, abertura e simplicidade relacionam-se com a própria noção de um Estado que se queira democrático, em que a atividade financeira é realizada diante do povo, às suas vistas, e

\footnotetext{
${ }^{75}$ ABRAHAM, Marcus. Reflexões sobre finanças públicas e direito financeiro. Salvador: Editora JusPodivm, 2019.

${ }^{76}$ ABRAHAM, Marcus. Os Princípios Reitores da Lei de Responsabilidade Fiscal e as Lições de Ricardo Lobo Torres. In: Direitos Fundamentais e Estado Fiscal: estudos em homenagem ao Professor Ricardo Lobo Torres. CAMPOS, Carlos Alexandre de Azevedo; OLIVEIRA, Gustavo da Gama Vital de; e MACEDO, Marco Antonio Ferreira (Coordenadores). Salvador: JusPodivm, 2019.
} 
apresentada de tal forma que as informações possam ser compreensíveis. A publicidade no trato com o dinheiro público auxilia a dar sustentação e legitimar o sistema democrático como governo do povo e para o povo (ABRAHAM, 2019, pp. 358/359).

E para que a transparência fiscal efetivamente se concretize, em estrito respeito aos valores da gestão fiscal responsável, não basta a mera publicação de dados - ainda pior se eles forem publicados em duplicidade e com valores distintos.

Dessarte, força há em convir com Marcus Abraham7 que "a transparência não se expressa apenas pela quantidade de informações, mas também pela sua qualidade, objetividade, inteligibilidade e, sobretudo, utilidade" (ABRAHAM, 2019, p. 359).

É indubitável o fato de que a Lei de Responsabilidade Fiscal não pretendeu uma multiplicidade de relatórios de gestão fiscal, como se realidades matemáticas comportassem resultados interpretativos a depender de quem as analisa. A leitura dos arts. 54 e 55 da Lei Complementar $n^{\circ}$ 101/00 não deixa margem de dúvida a esse respeito:

LRF, Art. 54. Ao final de cada quadrimestre será emitido pelos titulares dos Poderes e órgãos referidos no art. 20 Relatório de Gestão Fiscal, assinado pelo: I - Chefe do Poder Executivo; II - Presidente e demais membros da Mesa Diretora ou órgão decisório equivalente, conforme regimentos internos dos órgãos do Poder Legislativo; III - Presidente de Tribunal e demais membros de Conselho de Administração ou órgão decisório equivalente, conforme regimentos internos dos órgãos do Poder Judiciário;

IV - Chefe do Ministério Público, da União e dos Estados.

Parágrafo único. $\mathrm{O}$ relatório também será assinado pelas autoridades responsáveis pela administração financeira e pelo controle interno, bem como por outras definidas por ato próprio de cada Poder ou órgão referido no art. 20. Art. 55. O relatório conterá:

I - comparativo com os limites de que trata esta Lei Complementar, dos seguintes montantes:

a) despesa total com pessoal, distinguindo a com inativos e pensionistas;

Obviamente, esses documentos só poderão concretizar-se como instrumentos de transparência fiscal se neles houver credibilidade para uma precisa aferição da realidade fiscal por eles retratada, de modo a respeitar o art. 48 da Lei de Responsabilidade Fiscal:

Art. 48. São instrumentos de transparência da gestão fiscal, aos quais será dada ampla divulgação, inclusive em meios eletrônicos de acesso público: os planos, orçamentos e leis de diretrizes orçamentárias; as prestações de contas e o respectivo parecer prévio; o Relatório Resumido da Execução Orçamentária e o Relatório de Gestão Fiscal; e as versões simplificadas desses documentos (grifos nossos).

${ }^{77}$ Ob. cit. 
Nesse sentido caminha a doutrina de Gilmar Mendes $^{78}$, enfatizando a imprescindibilidade da transparência fiscal no direito financeiro, atrelado que está à segurança orçamentária, além de ser fator legitimador da atividade financeira do Estado, consoante passagem pertinente a comentários ao art. 48 da Lei de Responsabilidade Fiscal:

O princípio da transparência ou clareza foi estabelecido pela Constituição de 1988 como pedra de toque do Direito Financeiro. Poderia ser considerado mesmo um princípio constitucional vinculado à ideia de segurança orçamentária. Nesse sentido, a ideia de transparência possui a importante função de fornecer subsídios para o debate acerca das finanças públicas, o que permite uma maior fiscalização das contas públicas por parte dos órgãos competentes e, mais amplamente, da própria sociedade. A busca pela transparência é também a busca pela legitimidade (MENDES, 2014, posição 8515, em comentários ao artigo 48).

E assim o é, pois, "no contexto específico da Lei de Responsabilidade Fiscal, a transparência aparece como princípio da gestão orçamentária responsável ou como subprincípio do princípio da responsabilidade" (MENDES, 2014, posição 8520, em comentários ao artigo 48).

No entanto, conquanto seja clara a conduta exigida pela transparência fiscal, os documentos que deveriam espelhar o real estado dos gastos com pessoal de cada ente da Federação - em número crescente de casos — variam em função de serem entregues ao Tribunal de Contas local ou à Secretaria do Tesouro Nacional, com diferenças na ordem de milhões de reais, capazes de pintar quadros tão díspares quanto o pleno cumprimento dos limites de despesas com pessoal e a absoluta ofensa a esses mesmos limites.

As tintas mudam não em função do observado, mas de acordo com o observador, com uma aferição canhestra da realidade dos gastos com pessoal e, por conseguinte, com mera divulgação formal de dados pouco úteis e confiáveis. Com tal proceder, jamais se coadunará a efetiva transparência fiscal, como bem destacado por Marcus Abraham ${ }^{79}$ :

Nesse passo, como ressalva Jean Starobinski, a transparência fiscal não pode ser vista apenas, ou simplesmente, sob a ótica do acesso à informação, mas seu conceito deve ser compreendido de maneira abrangente, abarcando outros elementos tais como responsividade, accountability, combate à corrupção, prestação de serviços públicos, confiança, clareza e simplicidade (ABRAHAM, 2019, p. 359).

\footnotetext{
${ }^{78}$ MENDES, Gilmar. Comentários aos arts. 48 a 59. In: Comentários à Lei de Responsabilidade Fiscal, 7 a edição (edição eletrônica). MARTINS, Ives Gandra; e NASCIMENTO, Carlos Valder do (organizadores). São Paulo: Saraiva, 2014.

79 ABRAHAM, Marcus. Os Princípios Reitores da Lei de Responsabilidade Fiscal e as Lições de Ricardo Lobo Torres. In: Direitos Fundamentais e Estado Fiscal: estudos em homenagem ao Professor Ricardo Lobo Torres. CAMPOS, Carlos Alexandre de Azevedo; OLIVEIRA, Gustavo da Gama Vital de; e MACEDO, Marco Antonio Ferreira (Coordenadores). Salvador: JusPodivm, 2019.
} 
Esse fato reforça a hipótese da falha sistêmica no controle de despesas com pessoal, pois o ordenamento jurídico não encontrou meios eficazes, até o presente momento, de sanar essa incoerência prescritiva.

Além disso, força há em convir que a não aplicação correta dos limites de gastos com pessoal, em todas as suas nuances, é capaz de infirmar a consecução das finalidades mais precípuas do Estado, dada a insustentabilidade fiscal dos caminhos trilhados por diversos entes federativos desde o advento da Lei de Responsabilidade Fiscal, invariavelmente com o beneplácito de um controle tentado a acomodar situações-limite.

Daí a necessidade de o problema ser enfrentado a partir da perspectiva de construção de um regime jurídico coerente e do qual possam ser extraídas soluções harmônicas com todo o sistema, no sentido oposto da observada profusão de criações interpretativas ao sabor das circunstâncias de cada caso concreto.

E, conforme delineado no item 1.2 supra, o sistema de controle de pessoal também tem falhado sistematicamente ao permitir que haja prolongada permanência de gastos com pessoal acima dos limites de alerta e prudencial da Lei de Responsabilidade Fiscal, potencializando riscos fiscais que deveriam ser prevenidos por esse mesmo sistema.

Outrossim, há nítidas barreiras para a efetiva aplicação das sanções da Lei de Responsabilidade Fiscal, mesmo nas hipóteses em que nem a contabilidade criativa é capaz de disfarçar o excesso de gastos em face dos limites da LRF.

De fato, têm-se tornado relativamente frequentes liminares do Supremo Tribunal Federal para afastar as sanções aos entes decorrentes da Lei de Responsabilidade Fiscal nas hipóteses em que os dispositivos de contenção de despesas deveriam ser reforçados.

Assim o foi na medida cautelar deferida pelo STF na Ação Cível n ${ }^{\circ}$ 2.659/MS ${ }^{80}$, a qual permitiu que operações de crédito fossem realizadas pelo estado do Mato Grosso do Sul, não obstante o fato de que o Poder Judiciário daquele ente federativo tivesse ultrapassado o limite de despesa com pessoal a ele designado pela Lei de Responsabilidade Fiscal, in verbis:

AÇÃO CAUTELAR PREPARATÓRIA. MEDIDA
IMPEDIMENTO À REALIZAÇÃO DE CONTRATAÇÃO DE OPERAÇÕES
DE CRÉDITO DESTINADAS AO PROGRAMA EMERGENCIAL DE
FINANCIAMENTO 2 PEF2, AO PROFISCO E AO PROGRAMA DE
TRANSPORTES E DE DESENVOLVIMENTO SUSTENTÁVEL DO
ESTADO DE MATO GROSSO DO SUL PDE/MS. RESTRIÇÕES, QUE,

${ }^{80}$ AC 2659 MCREF/MS MATO GROSSO DO SUL REFERENDO NA MEDIDA CAUTELAR NA AÇÃO CAUTELAR. Relator(a): Min. CELSO DE MELLO. Julgamento: 12/08/2010. Órgão Julgador: Tribunal Pleno. Publicação DJe-179; DIVULG 23-09-2010; PUBLIC 24-09-2010; RTJ VOL-00216-01, PP-00196. 
EMANADAS DA UNIÃO, INCIDEM SOBRE O ESTADO DE MATO GROSSO DO SUL, POR ALEGADO DESCUMPRIMENTO, POR PARTE DE SEU PODER JUDICIÁRIO, DO LIMITE SETORIAL QUE A LEI DE RESPONSABILIDADE FISCAL IMPÕE A TAL ÓRGÃO PÚBLICO (LC No 101/2000, ART. 20, II, "B"). (...) CAUTELAR FUNDADA NAS ALEGAÇÕES DE OFENSA AO PRINCÍPIO DA INTRANSCENDÊNCIA DAS MEDIDAS RESTRITIVAS DE DIREITOS. (...) O ALTO SIGNIFICADO DA LEI DE RESPONSABILIDADE FISCAL E A QUESTÃO DE SUA APLICABILIDADE AO ESTADO DE MATO GROSSO DO SUL: LIMITE GLOBAL E LIMITE SETORIAL EM TEMA DE DESPESA COM PESSOAL (PODER JUDICIÁRIO). O Poder Executivo estadual não pode sofrer sanções nem expor-se a restrições emanadas da União Federal, em matéria de realização de operações de credito, sob a alegação de que o Poder Judiciário, a Assembleia Legislativa, o Tribunal de Contas e o Ministério Público locais teriam descumprido o limite individual a eles imposto pela Lei de Responsabilidade Fiscal (art. 20, inciso II, "a", "b" e "d"), pois o Governo do Estado não tem competência para intervir na esfera orgânica de referidas instituições, que dispõem de plena autonomia institucional a elas outorgada por efeito de expressa determinação constitucional. Precedentes.

Vale dizer, a partir do princípio da intranscedência subjetiva, o Supremo Tribunal Federal tem afastado uma das principais consequências da Lei de Responsabilidade Fiscal quanto ao descumprimento dos limites de gastos com pessoal, tornando a norma imperfeita e com limitada concretização prática.

No mesmo sentido, dessa feita em relação ao Distrito Federal, o Supremo Tribunal Federal $^{81}$ afastou cautelarmente a recusa da União de fornecer aval para operação internacional de crédito, descaracterizando para tanto o motivo sobre o qual se pautava o agir federal, qual seja, a ultrapassagem dos limites específicos da Câmara Legislativa Distrital e do Tribunal de Contas do Distrito Federal:

RECUSA DE PRESTAÇÃO DE AVAL PELA UNIÃO FEDERAL E NEGATIVA DE AUTORIZAÇÃO, POR PARTE DA SECRETARIA DO TESOURO NACIONAL (OFÍCIO No 10.540/2008COPEM/STN). (...) PRETENSÃO CAUTELAR FUNDADA NAS ALEGAÇÕES DE OFENSA AO PRINCÍPIO DA INTRANSCENDÊNCIA DAS MEDIDAS RESTRITIVAS DE DIREITOS. MEDIDA CAUTELAR DEFERIDA. DECISÃO DO RELATOR REFERENDADA PELO PLENÁRIO DO SUPREMO TRIBUNAL FEDERAL. O Poder Executivo do Distrito Federal não pode sofrer sanções nem expor-se a restrições impostas pela União Federal em tema de celebração de operações financeiras internacionais (recusa de prestação de aval e negativa de autorização), sob a alegação de que o Tribunal de Contas e o Poder Legislativo locais embora observando o índice setorial de 3\% teriam descumprido, cada qual, os limites individuais a eles impostos pela Lei de Responsabilidade Fiscal (art. 20, inciso II, "a"), pois o Governo do Distrito Federal não tem competência para intervir na esfera orgânica da Câmara Legislativa e do Tribunal de Contas, por se tratar de órgãos investidos de autonomia institucional, por força e efeito

${ }^{81}$ AC 2197 MCREF / DF DISTRITO FEDERAL. REFERENDO NA MEDIDA CAUTELAR NA AÇÃO CAUTELAR. Relator(a): Min. CELSO DE MELLO. Julgamento: 13/11/2008. Órgão Julgador: Tribunal Pleno. Publicação: DJe-213. DIVULG 12-11-2009, PUBLIC 13-11-2009, EMENT VOL-02382-01, PP-00050. 
de expressa determinação constitucional. Precedentes. (...) NECESSIDADE DE OUTORGA DE PROVIMENTO CAUTELAR, NO CASO, EM ORDEM A NÃO FRUSTRAR A REGULAR PRESTAÇÃO, NO PLANO LOCAL, DE SERVIÇOS PÚBLICOS ESSENCIAIS.

Outrossim, a responsabilidade fiscal no Brasil vive atualmente potencial momento de inflexão, com diversos questionamentos quanto à eficácia e à extensão dos limites de gastos com pessoal, com nuances que vão da incorporação de novos gastos, até então não abrangidos para fins da contenção da Lei de Responsabilidade Fiscal, até a pretensão de flexibilização de suas normas, por supostamente gerarem efeitos pró-cíclicos sobre as crises econômicas, haja vista a denominada "Nova Matriz Econômica", que redundou na maior recessão da História do país.

\title{
1.6 DA SUSTENTABILIDADE DO ESTADO FISCAL NO SÉCULO XXI
}

À evidência, nada obstante nossas mazelas locais, vivemos um generalizado momento de crise do Estado fiscal, cujo suporte financeiro enfrenta novos paradigmas neste primeiro quarto de século, em meio a complexos desafios para atender a crescente demanda por mais recursos públicos.

Não sendo o Brasil uma ilha alheia aos fenômenos globais, não se pode analisar o quadro de nossas despesas públicas com os olhos fechados à internacionalização, à integração e à globalização econômicas, diretamente implicadas com a elasticidade do suporte financeiro do Estado.

De fato, esse quadro é bem delineado na doutrina do Prof. José Casalta Nabais ${ }^{82}$, da Universidade de Coimbra, conforme segue:

\begin{abstract}
Depois, relativamente aos fenómenos mais importantes da mencionada crise, podemos dizer que se trata de realidades que atuam em dois níveis: de um lado, reportam-se à subsistência do Estado moderno; de outro lado, respeitam à manifestação desse mesmo Estado na forma que assumiu na segunda metade do século XX - o Estado social. Realidades que abrangem os fenómenos da internacionalização, da integração e da globalização económicas, os quais constituem verdadeiros "desafios externos" à soberania fiscal dos Estados (NABAIS, 2011, p. 20).
\end{abstract}

A esses fatores, some-se o limitador da capacidade de implemento de receitas pelos países decorrente da liberdade de circulação de capitais, cuja consequência inexorável é a

\footnotetext{
${ }^{82}$ NABAIS, José Casalta. Da Sustentabilidade do Estado Fiscal. In: Sustentabilidade Fiscal em Tempos de Crise. Coordenadores: NABAIS, José Casalta e DA SILVA, Suzana Tavares. Coimbra: Almedina, 2011, pp. 11-59.
} 
constante insuficiência de recursos para o Estado fiscal fazer frente às crescentes demandas da sociedade.

Nas palavras de Casalta Nabais ${ }^{83}$ :

Por seu turno, o fenómeno da globalização, que vem engendrando a nível mundial uma liberdade de circulação para os capitais, para os bens e até, embora em menor grau, para as pessoas, dando suporte a uma verdadeira "concorrência entre os Estados" em diversos domínios, entre os quais se inclui com particular visibilidade a tributação, veio limitar a soberania fiscal dos Estados, não podendo estes, no quadro de uma economia aberta, instituir ou manter os impostos que entenderem. Daí que o problema actualmente seja o da insuficiência da receita fiscal decorrente dessa concorrência. Temos assim uma competitividade, uma concorrência entre sistemas fiscais que leva os Estados a reduzir sobretudo a tributação das empresas, bem como a permitir que estas utilizem diversos instrumentos para reduzir sua matéria colectável, como acontece, por exemplo, com os preços de transferência (NABAIS, 2011, p. 21).

De fato, o cenário ora vivido pelo Estado Fiscal decorre da intensificação dos desafios fiscais constantemente anabolizados por crises econômicas, cujos efeitos negativos serão mais profundos quanto mais frágil seja a estrutura fiscal, no que tange à sustentabilidade financeira.

Cite-se, exemplificativamente, a descrição da crise vivida no final da década de 1970, nas palavras de Ricardo Lobo Torres ${ }^{84}$ :

No final da década de 1970, após as sucessivas crises do petróleo, o Estado de Bem-estar Social passa a sofrer séria contestação, em virtude do crescimento insuportável da dívida pública, dos orçamentos repetidamente deficitários, da recessão econômica e do abuso na concessão de benefícios com o dinheiro público; a sua dimensão assistencialista conduz ao incremento das despesas com a previdência e a seguridade social sem a contrapartida da entrada de ingressos compatíveis com o volume dos encargos e, não raro, com o seu custeio pela incidência exageradamente progressiva dos impostos (TORRES, 2009, p. 540).

Sendo certos os desafios universais para o atual suporte financeiro do Estado fiscal, ainda mais premente se torna a necessidade de um adequado controle das despesas, em especial as de caráter continuado e obrigatório como as relativas aos gastos com pessoal ${ }^{85}$, haja vista a incapacidade estatal de controlar as flutuações de receitas públicas e sua tendência secular de declínio.

Com os olhos voltados para essa realidade inexorável, a Lei de Responsabilidade

\footnotetext{
${ }^{83}$ Ob. cit.

84 TORRES, Ricardo Lobo. Tratado de direito constitucional financeiro e tributário, Vol. I - Constituição financeira, sistema tributário e estado fiscal.. - Rio de Janeiro: Renovar, 2009.

${ }^{85}$ Lei de Responsabilidade Fiscal, art. 17: Considera-se obrigatória de caráter continuado a despesa corrente derivada de lei, medida provisória ou ato administrativo normativo que fixem para o ente a obrigação legal de sua execução por um período superior a dois exercícios.
} 
Fiscal foi bastante ciosa no controle de despesas com pessoal, desde a sua geração até a limitação do seu montante, de modo que a gestão fiscal destes gastos haveria de pautar-se pela prudência, consoante delineado por Carlos Maurício Figueiredo e Marcos Nóbrega ${ }^{86}$ :

A LRF introduziu uma mudança substancial na lógica da geração da despesa pública. Se antes de sua edição o requisito fundamental para criação de despesas era a existência de crédito orçamentário, a partir de 05.05.2000 passa-se a exigir, também, suporte financeiro, além do cumprimento dos diversos limites fixados naquela lei complementar.

No capítulo da 'Despesa Pública', aquela relativa a pessoal mereceu tratamento específico. A LRF determina a obediência a limites, prazos de enquadramento, e, conforme seus princípios, em especial o da Prudência, estabelece regras para previnir riscos e corrigir desvios capazes de afetar o equilíbrio das contas públicas (FIGUEIREDO, et al., 2006, pp. 74/75).

Em não havendo um adequado controle de despesas deste jaez, caminha-se em direção a gravíssimo e insustentável quadro físcal, passível de atingir uma crise de caráter absoluto, delineada por Ricardo Lobo Torres ${ }^{87}$ :

A crise do Estado Fiscal pode se agravar até se tornar absoluta (absolute crisis of the tax state), quando então seriam inócuas as modificações institucionais da política fiscal, da função tributária e do orçamento governamental. Critica-se a crença na inesgotabilidade dos recursos públicos (TORRES, 2009, p. 542).

Diante do risco de comprometimento do equilíbrio fiscal, em um Estado que já possui naturalmente dificuldades no que tange ao seu suporte financeiro, não haveria outro caminho a ser seguido pela LRF senão racionalizar a criação e expansão das despesas com pessoal.

Nesse sentido, são categóricas as palavras de Carlos Maurício Figueiredo e Marcos Nóbrega:

Dessa forma, a lei impõe uma série de restrições para a criação de uma nova despesa de pessoal. Trata-se de parâmetros diversos que visam imprimir um cunho de 'racionalidade fiscal quando da implantação de medidas que possam comprometer o equilíbrio entre receitas e despesas (FIGUEIREDO, et al., 2006, p. 75).

Por outro lado, em consonância com a tendência de declínio da base arrecadatória do Estado fiscal, com as inexoráveis consequências para o seu suporte financeiro, lê-se na doutrina de Marcus Abraham ${ }^{88}$ :

\footnotetext{
${ }^{86}$ FIGUEIREDO, Carlos Maurício; NÓBREGA, Marcos. Lei de Responsabilidade Fiscal: aspectos polêmicos. Belo Horizonte: Fórum, 2006.

87 TORRES, Ricardo Lobo. Tratado de direito constitucional financeiro e tributário, Vol. I - Constituição financeira, sistema tributário e estado fiscal.. - Rio de Janeiro: Renovar, 2009.

${ }^{88}$ ABRAHAM, Marcus. Governança fiscal e sustentabilidade financeira: os reflexos do Pacto Orçamental
} 
A circulação de capitais por meio de intrincadas operações em escala global implica a criação de fatos geradores que os Estados nacionais, por meio de sua legislação nacional ou mesmo de acordos multilaterais de tributação em nível internacional, são incapazes de tributar eficazmente. Esse fenômeno, bastante comum na realidade do direito tributário internacional, acaba por reduzir as bases tributárias dos países envolvidos, com a consequente perda de arrecadação (ABRAHAM, 2019, p. 152).

Outrossim, essa é uma realidade de tal sorte relevante para o Estado fiscal no século XXI, que a Organização para a Cooperação e Desenvolvimento Econômico (OCDE) busca contornar por intermédio de plano de ação iniciado em 2013, nos termos descritos por Marcus Abraham $^{89}$ :

Por esse motivo, a Organização para a Cooperação e Desenvolvimento Econômico (OCDE), em um plano de ação de 2013 (Adressing Base Erosion and Profit Shifting - BEPS), dimensionou as perdas enfrentadas pelos países diante da erosão fiscal e transferência de lucros para jurisdições de baixa tributação, expondo a preocupação com a redução das bases tributárias dos países-membros e a necessidade de adotar as medidas para harmonização da legislação tributária internacional (ABRAHAM, 2019, p. 152) (grifos originais).

Ademais, fixando o olhar no Brasil, observa-se o quanto nossas receitas estão sujeitas a choques aleatórios internacionais, com uma matriz econômica calcada em commodities.

Em assim sendo, há uma grande amplitude na variação de receitas ao longo do tempo, sendo constante a situação insustentável de despesas ordinárias e contínuas como as despesas de pessoal serem honradas por intermédio de receitas extraordinárias, com o consequente efeito colateral de agravamento dos riscos e o eterno adiamento da adoção de soluções definitivas.

Fernando Rezende ${ }^{90}$ descreve à perfeição a insustentabilidade do círculo vicioso de despesas ordinárias arcadas com receitas extraordinárias, conforme lê-se:

Outra consequência da forma como a discussão das despesas vem sendo conduzida é a desconsideração da importância de combinar as espécies de despesas e receitas. Uma regra de ouro aplicada às finanças públicas é a que estabelece que recursos provenientes de operações de crédito só deveriam ser usados para financiar investimentos e que as despesas de custeio não podem depender de receitas extraordinárias, ou de outras fontes com elevada instabilidade.

Quando as despesas obrigatórias absorvem a maioria, ou chegam a superar as receitas ordinárias, gastos essenciais que não contam com alguma proteção legal ficam na dependência do acesso a receitas extraordinárias e incertas, além do recurso ao endividamento (REZENDE, 2016, p. 55).

Europeu em Portugal como exemplos para o Brasil. Belo Horizonte: Fórum, 2019.

${ }^{89}$ Ob. cit.

${ }^{90}$ REZENDE, Fernando. Em busca do tempo perdido: é preciso buscar o fio da meada para desembaraçar o novelo fiscal. Rio de Janeiro: FGV Editora, 2016. 
E como sói haveria de ser, a eternização dessa rotina termina por ensejar uma falha estrutural que se acumula ao longo dos anos com um postergar constante da solução para o problema, muitas vezes camuflado por medidas de curto prazo para resolver os efeitos visíveis, sem atacar a efetiva causa.

Nessa linha, conclui Fernando Rezende ${ }^{91}$ :

A medida adotada para aferir o desequilíbrio financeiro adiciona outro fator que agrava os desequilíbrios estruturais e temporais. O foco no superavit primário, que é medida predominante no Brasil, deixa em segundo plano as outras dimensões do equilíbrio orçamentário. A combinação de receitas extraordinárias com o represamento de gastos (acúmulo de Restos a Pagar) ajuda a fechar a conta do ano, mas contribui para a acumulação de inúmeros problemas que apenas adiam o enfrentamento dos desequilíbrios estruturais e temporais que irão demandar um esforço muito maior posteriormente para serem solucionados (REZENDE, 2016, p. 55/56).

Diante dessa realidade que nos acompanha por anos a fio, força há em convir com a necessidade de reestruturar o regime jurídico do controle de despesas com pessoal, de modo a rechaçar os problemas estruturais acima apontados.

${ }^{91}$ Ob. cit. 


\section{CAPÍTULO VIII \\ CONCLUSÃO}

\section{SÍNTESE CONCLUSIVA}

Diante de tudo quanto exposto, força há em convir com a generalizada disfuncionalidade do sistema de controle de despesas com pessoal atual, nada obstante os avanços representados pela Lei de Responsabilidade Fiscal quanto à previsão de instrumentos jurídicos voltados para o equilíbrio fiscal.

Feita essa constatação, observa-se que a eficácia das prescrições normativas pressupõe um sistema jurídico adequadamente construído a partir de princípios estruturantes, os quais irão garantir unidade ao sistema e coerência aos elementos que o compõem, além de fornecer uma imprescindível conexão de sentido entre as diversas normas, de modo a amalgamá-las em torno de uma finalidade comum.

Nesse sentido, o regime jurídico de controle de despesas com pessoal há de estar lastreado em um bem traçado regime jurídico financeiro, com normas calcadas nos princípios da supremacia do interesse público, indisponibilidade do interesse público pela Administração Pública, solidariedade fiscal e responsabilidade fiscal.

E assim o é, pois, o regime jurídico financeiro disciplina atividades financeiras que são desenvolvidas no âmbito do exercício das funções administrativas e legislativas, de modo a fornecer os requisitos de validade para a produção atos concretizadores da finalidade de interesse público atinentes à gestão fiscal responsável.

Nesse sentido, por exemplo, o regime jurídico financeiro baliza a geração de novas despesas públicas, amoldando-as ao montante de dispêndios já realizados e previstos para serem realizados, inclusive os obrigatórios de caráter continuado, além de requerer a projeção do impacto futuro de determinados tipos de despesas com o fito de rechaçar riscos fiscais potencialmente desequilibradores das contas públicas e, a longo prago, que possam vir a comprometer a sustentabilidade financeira.

Com essas balizas, deve ser traçado um Estado Democrático Fiscal capaz de rechaçar riscos fiscais e potencializar a gestão fiscal responsável, em que se realizam os direitos fundamentais e sociais com preocupações de sustentabilidade fiscal garantidoras do atendimento das necessidades coletivas a longo prazo.

Sobre essa estrutura normativa, enraizada pelos princípios estruturantes do regime 
jurídico financeiro, deverá ser erguido o regime jurídico de controle de despesas com pessoal, constitucionalmente requerido, notadamente pelos artigos 163 e 169 da Constituição da República e, com isso, garantidor da realização do interesse público atinente a um adequado equilíbrio entre meios e fins pertinentes à gestão fiscal responsável.

Para tanto, faz-se imprescindível repensar o papel das normas de controle das despesas com pessoal dentro deste subsistema, com uma mínima uniformidade de interpretação e aplicação, notadamente quanto às normas gerais de direito financeiro.

Igualmente, faz-se necessário fechar as brechas do sistema que atualmente permitem manobras para se eximir dos controles de despesas com pessoal, quer seja em relação à terceirização ou mesmo a mudança de natureza jurídica de determinadas despesas.

Fincado esses parâmetros, volta-se os olhos para esboçar respostas às indagações consubstanciadoras da problemática trabalhada nesta tese.

\subsection{INDAGAÇÕES CONCEITUAIS DO DIREITO FINANCEIRO}

Em conformidade com a argumentação desenvolvida no Capítulo IV, o Direito Financeiro colhe os princípios decorrentes do Direito Público, notadamente os decorrentes do exercício da função administrativa, a qual é central para a concretização da atividade financeira.

No entanto, a atividade financeira do Estado Democrático Fiscal não se restringe ao exercício da função administrativa, pois ela também se concretize por intermédio da função legislativa, mormente no que concerne aos atos preparatórios das leis orçamentárias, bem como quanto às escolhas alocativas de recursos públicos.

Dessa forma, tem-se um regime jurídico financeiro específico para delinear a atividade financeira do Estado. Neste, os princípios da supremacia do interesse público, da indisponibilidade do interesse público pela Administração, da Solidariedade Fiscal e da Responsabilidade Fiscal são estruturantes.

E quanto ao conceito central de despesa pública nesse regime jurídico financeiro, tem-se como imperioso agregar o fator tempo ao clássico conceito de Aliomar Baleeiro atinente ao "conjunto de dispêndios", de modo a capturar todos os requisitos de validade extraídos do ordenamento jurídico.

Assim, deve-se agregar uma nuance dinâmica ao conceito de despesa pública, o que proporcionará uma análise completa dos efeitos jurídicos dele extraíveis, bem como a devida conduta esperada pelo ordenamento jurídico como legítima. 


\subsection{INDAGAÇÕES QUANTO À SUSTENTABILIDADE FISCAL}

Consoante delineado no Capítulo $\mathrm{V}$, as medidas explícitas do regime jurídico de controle de despesas com pessoal não são eficazes para prevenir riscos fiscais nem tampouco para garantir o equilíbrio fiscal, no que tange aos limites de alerta e prudencial de gastos com pessoal.

Com efeito, quanto ao limite de alerta, a interpretação feita pelos ordenadores de despesas e pelos emissores do alerta quanto aos deveres decorrentes do art. 59, $\S 1^{\circ}$, inciso II, da Lei de Responsabilidade Fiscal, restringe a finalidade do dispositivo a mera ciência do gestor público quanto ao patamar atingido pelos gastos com pessoal.

No que diz respeito ao limite prudencial, a detecção de que os gastos com pessoal ultrapassaram o montante de $95 \%$ do limite total de despesas com pessoal redundaria exclusivamente em deveres jurídicos negativos atinentes a não praticar atos geradores de aumento das despesas com pessoal, prescritos no art. 22, parágrafo único, da Lei de Responsabilidade Fiscal.

Ocorre que, não se deve restringir os efeitos da ultrapassagem desses limites de despesas com pessoal às consequências expressamente estabelecidas na Lei de Responsabilidade Fiscal em dispositivos que delineiam estas condutas como antecedentes normativos.

Com efeito, assim proceder seria desconsiderar a natureza jurídica desses limites, os quais se consubstanciam em instrumentos para evitar o efetivo atingimento do limite total de despesas com pessoal, além de menoscabar os princípios retores da responsabilidade fiscal.

Em assim sendo, e em consonância com o art. $1^{\circ}, \S 1^{\circ}$, da Lei de Responsabilidade Fiscal, ultrapassar os limites parciais de gastos com pessoal implica na necessidade de corrigir desvios capazes de afetar o equilíbrio das contas públicas, o que exige do gestor público e dos órgãos de controle a adoção de medidas concretas nesse sentido, quais sejam: I) verificar a geração de despesas com pessoal nos últimos 3 exercícios financeiros, de modo a aferir se efetivamente foi procedido estudo de impacto orçamentário-financeiro com o rigor exigido pelos arts. 16 e 17 da Lei de Responsabilidade Fiscal; II) verificar a ocorrência das hipóteses de nulidades de pleno direito previstas no art. 15 da Lei de Responsabilidade Fiscal, com a consequente retirada dos seus efeitos do mundo jurídico; III) analisar se o ente obedece o requisito essencial à responsabilidade na gestão fiscal concernente à instituição, previsão e efetiva arrecadação de todos os tributos da competência constitucional do ente da Federação, em consonância com o art. 11 da Lei de Responsabilidade Fiscal, com a adoção das 
providências cabíveis; IV) analisar se as renúncias de receitas procedidas nos três exercícios anteriores obedeceram ao quanto disposto no art. 14 da Lei de Responsabilidade Fiscal, com a adoção das providências cabíveis no caso de desobediência do dispositivo, a começar por sua nulidade.

E assim o é, pois, permanecer em patamares superiores aos limites parciais de despesas com pessoal tendem a deteriorar as contas públicas, além de submeter a gestão fiscal a riscos contingenciais que poderão levar os gastos a patamares dificilmente solucionáveis com os dispositivos previstos no ordenamento jurídico, o que poderá acarretar a completa insolvência do Estado.

Outrossim, as vedações decorrentes do limite prudencial são potenciais geradoras de efeitos colaterais negativos sobre a capacidade de realizar o interesse público a longo prazo, pois, gradativamente, os meios necessários para a sua concretização não mais estarão disponíveis.

Dessarte, em face da inexistência de um prazo expressamente estipulado para permanecer acima dos limites parciais de gastos com pessoal, toma-se como parâmetro o prazo estabelecido para que o excesso decorrente da ultrapassagem do limite total de despesas com pessoal seja expurgado, quais sejam: I) dois quadrimestres no caso de condições econômicas normais (art. 23, LRF); II) quatro quadrimestres, na hipótese de crescimento real baixo ou negativo do Produto Interno Bruto (PIB) nacional, regional ou estadual por período igual ou superior a quatro trimestres (art. 66, LRF).

\subsection{INDAGAÇÕES ESPECÍFICAS QUANTO AOS LIMITES DA LEI DE RESPONSABILIDADE FISCAL}

A verificação dos valores jurídicos quanto à zona de condutas legítimas, bem como a imperiosidade de não submeter a gestão fiscal a riscos de desequilíbrios desnecessários, conjugado com o princípio da prudência fiscal, implica na antijuridicidade de condutas omissivas deliberadas que estagnem as despesas com pessoal em patamares que ultrapassem os limites parciais previstos na Lei de Responsabilidade Fiscal.

Portanto, é incompatível com os princípios inerentes à responsabilidade fiscal deixar de tomar todas as providências necessárias para corrigir esse desvio configurado na constância do excesso de gastos, ainda que não tenha sido ultrapassado o limite total de gastos. Desse modo, acaso sejam ultrapassados dois quadrimestres de prolongamento dessa situação - ou quatro quadrimestres, nas hipóteses previstas no art. 66 da Lei de Responsabilidade Fiscal —, ter-se-á 
presunção relativa de que as renúncias de receitas ocorridas nesse período foram inválidas, cabendo ao gestor fiscal demonstrar que elas não impactaram negativamente as contas públicas.

À evidência, a omissão dolosa em corrigir os desvios fiscais capazes de desequilibrar as contas públicas e os atos comissivos que vierem a agravar essa situação de comprometimento são passíveis de sanção, mediante a devida comprovação, inclusive as decorrentes de dano ao erário, em face do quanto previsto no art. 15 da Lei de Responsabilidade Fiscal.

Por fim, em face da constatação de que a Lei de Responsabilidade Fiscal decorre igualmente de autorização constitucional dos artigos 163 e 169 da Constituição da República, bem como da necessidade de limites parciais para concretizar o anseio constitucional de contenção das despesas públicas, verifica-se a constitucionalidade do art. 20 da Lei Complementar $\mathrm{n}^{\mathrm{o}} 101 / 00$.

E a necessidade de limites parciais estende-se aos órgãos que tenham adquirido autonomia financeira posteriormente à promulgação da Lei de Responsabilidade Fiscal, sendo o montante extraído do Poder no qual ele estava originalmente vinculado, como é o caso da Defensoria Pública em relação ao Poder Executivo do respectivo ente da Federação.

Para tanto, deverá ser estabelecido mecanismo de transição análogo ao estabelecido no momento de implantação da Lei de Responsabilidade Fiscal, em consonância com os artigos $20, \S 1^{\circ}$, e art. 70 da Lei de Responsabilidade Fiscal.

\subsection{INDAGAÇÕES QUANTO À ATUAÇÃO DOS TRIBUNAIS DE CONTAS}

A previsão normativa da competência de responder consultas, gerando precedentes normativos, atribuída aos tribunais de contas, não tem o condão de transmudá-los em legisladores com discricionariedade para alterar os dispositivos previstos em normas gerais de direito financeiro.

À evidência, extrair essa pretensão da competência de responder condutas transformariam o dispositivo em inconstitucional, pois, estaria a avançar sobre reserva de lei de caráter nacional, como é o caso da Lei de Responsabilidade Fiscal.

Ademais, a maior parte das disfuncionalidades do sistema de controle de despesas com pessoal decorre da multiplicidade de interpretações geradas pelos tribunais de contas, as quais tornam o sistema incoerente e anseiam por um mecanismo eficaz de uniformização dessas interpretações casuísticas.

Nesse sentido, uma alternativa é a efetivação do conselho de gestão fiscal previsto no art. 67 da Lei de Responsabilidade Fiscal, o qual teria que superar a dificuldade de implantação 
decorrente da multiplicidade de Poderes e órgãos legitimados para nele participar.

Alternativa diversa surge com a Proposta de Emenda Constitucional n ${ }^{\circ} 188$, de 2019, a qual pretende atribuir essa competência de uniformização ao Tribunal de Contas da União, mas que é passível de ser considerada inconstitucional em virtude do princípio federativo.

Como possibilidade de superação dessas barreiras — dificuldade de implantação do conselho de gestão físcal delineado pela LRF e potencial ofensa ao princípio federativo no modelo da PEC no 188/2019 —, ainda como ponderação de lege ferenda, haveria espaço para a criação de um Conselho Nacional de Contas nos moldes do Conselho Nacional de Justiça.

Mas, essas e qualquer outra alteração do direito positivo pertinente às despesas com pessoal, tenderão aos mesmos problemas de eficácia ora experimentados na tentativa de concretização de uma gestão fiscal responsável, acaso não haja uma profunda reestruturação do regime jurídico de controle de despesas com pessoal, sendo esta tese uma semente plantada neste sentido. 


\section{Bibliografia}

ABBAGNANO, Nicola. Dicionário de Filosofia. São Paulo: Martins Fontes, 2003. ABRAHAM, Marcus. Lei de Responsabilidade Fiscal Comentada, $2^{a}$ edição. Rio de Janeiro: Forense, 2017.

ABRAHAM, Marcus. Curso de Direito Financeiro Brasileiro, $5^{\text {a }}$ edição. Rio de Janeiro: Forense, 2018.

ABRAHAM, Marcus. Governança fiscal e sustentabilidade financeira: os reflexos do Pacto Orçamental Europeu em Portugal como exemplos para o Brasil. Belo Horizonte: Fórum, 2019.

ABRAHAM, Marcus. Os Princípios Reitores da Lei de Responsabilidade Fiscal e as Lições de Ricardo Lobo Torres. In: Direitos Fundamentais e Estado Fiscal: estudos em homenagem ao Professor Ricardo Lobo Torres. CAMPOS, Carlos Alexandre de Azevedo; OLIVEIRA, Gustavo da Gama Vital de; e MACEDO, Marco Antonio Ferreira (Coordenadores). Salvador: JusPodivm, 2019.

ABRAHAM, Marcus; GOMES, Marcus Lívio; TORRES, Heleno Taveira (Coord.). Direito financeiro na jurisprudência do Supremo Tribunal Federal: homenagem ao Ministro Marco Aurélio. Curitiba: Juruá, 2016.

ADEODATO, João Maurício. A retórica constitucional: Sobre tolerância, direitos humanos e outros fundamentos éticos do direito positivo. São Paulo: Saraiva, 2009. AFONSO, José Roberto. Responsabilidade Fiscal no Brasil: Uma Memória da Lei. Rio de Janeiro: FGV Projetos, 2010. Disponível em: https://bibliotecadigital.fgv.br/dspace/bitstream/handle/10438/6941/364.pdf AGUIAR, Afonso Gomes. Tratado da gestão fiscal. Belo Horizonte: Fórum, 2011. AGUIRRE DE CASTRO, Rodrigo Pironti (Coordenador). Lei de Responsabilidade Fiscal: ensaios em comemoração aos 10 anos da Lei Complementar $n^{0}$ 101/00. Belo Horizonte: Fórum, 2010.

AGUIRRE DE CASTRO, Rodrigo Pironti. A Lei de Responsabilidade Fiscal como fator determinante para a consolidação do sistema de controle interno: definição do entendimento da separação de poderes e o princípio da eficiência no "modelo gerencial" de Estado. In: AGUIRRE DE CASTRO, Rodrigo Pironti (Coordenador). Lei de Responsabilidade Fiscal: ensaios em comemoração aos 10 anos da Lei Complementar $n^{\circ}$ 101/00. Belo Horizonte: Fórum, 2010. 
AHUMADA, Guillermo. Tratado de Finanzas Públicas, Volumen I. Córdoba: Editorial Assandri, 1948.

ALMEIDA, Fernando Menezes. A noção constitucional de "administração pública" aplicada ao Poder Judiciário. In: CONTI, José Maurício (Coordenador). Poder Judiciário: orçamento, gestão e políticas públicas. São Paulo: Almedina, 2017.

AMARAL, Antônio Carlos Cintra do. Teoria do Ato Administrativo. Belo Horizonte: Fórum, 2008.

ARAGÃO, Alexandre Santos de. A "supremacia do interesse público"no advento do estado de direito e na hermenêutica do direito público contemporâneo. In: SARMENTO, Daniel (Org.) Interesses públivos versus interesses privados: desconstruindo o princípio da supremacia do interesse público. Rio de Janeiro: Lumen Juris, 2005.

ARAÚJO, Eugênio Rosa de. Direito Econômico \& Financeiro, $3^{\mathrm{a}}$ ed. Niterói/RJ: Impetus, 2013.

ATALIBA, Geraldo. República e Constituição, $3^{\text {a }}$ edição, atualizada por Rosolea Miranda Folgosi. São Paulo: Malheiros, 2011.

ATALIBA, Geraldo. Sistema Constitucional Tributário Brasileiro. São Paulo: Editora Revista dos Tribunais, 1968.

ÁVILA, Humberto. Constituição, Liberdade e Interpretação. São Paulo: Malheiros, 2019 .

ÁVILA, Humberto. Teoria da Segurança Jurídica, 5a edição. São Paulo: Malheiros, 2019.

BACELLAR FILHO, Romeu Felipe. Reflexões sobre direito administrativo. Belo Horizonte: Fórum, 2009.

BACELLAR FILHO, Romeu Felipe; HACHEM, Daniel Wunder (Coordenadores). Direito Administrativo e Interesse Público: estudos em homenagem ao Professor Celso Antônio Bandeira de Mello. Belo Horizonte: Fórum, 2010.

BALEEIRO, Aliomar. Uma Introdução à Ciência das Finanças, 19a edição revista e atualizada por Hugo de Brito Machado Segundo. Rio de Janeiro: Forense, 2015.

BANCO MUNDIAL. Relatório: Gestão de Pessoas e Folha de Pagamento no Setor Público Brasileiro: O que os dados dizem?, 2019.

BANCO MUNDIAL. Relatório: Sumário Executivo - Gestão de Pessoas e Folha de Pagamento no Setor Público Brasileiro: O que os dados dizem?. 2019.

BANDEIRA DE MELLO, Celso Antônio. O conteúdo do regime jurídico- 
administrativo e seu valor metodológico. In: Revista de Direito Administrativo (RDA), Vol. 89. Rio de Janeiro: FGV, 1967. Disponível em:

http://bibliotecadigital.fgv.br/ojs/index.php/rda/article/view/30088

BANDEIRA DE MELLO, Celso Antônio. Conflito entre União e Estado apoderamento pela União, sem recorrer ao Judiciário, de recursos tributários que a Constituição declara pertencentes aos Estados, para saciar-se de alegados créditos - inviabilidade. Revista trimestral de direito público, Vol. 33. São Paulo: Malheiros Editores, 2001.

BANDEIRA DE MELLO, Celso Antônio. Discricionariedade e Controle Jurisdicional, 2a edição. São Paulo: Malheiros, 2006.

BANDEIRA DE MELLO, Celso Antônio. Eficácia das Normas Constitucionais e Direitos Sociais. São Paulo: Malheiros, 2011.

BANDEIRA DE MELlo, Celso Antônio. Curso de Direito Administrativo. São Paulo: Malheiros, 2019, 34a edição.

BANDEIRA DE MELLO, Oswaldo Aranha. Princípios Gerais de Direito Administrativo, Vol. I, 3ª edição. São Paulo: Malheiros, 2007.

BECKER, Alfredo Augusto. Carnaval Tributário. São Paulo: Saraiva, 1989.

BERCOVICI, Gilberto. Desigualdades regionais, Estado e Constituição. SP: Max Limonad, 2003.

BERCOVICI, Gilberto; MASSONETTO, Luís Fernando. A Constituição Dirigente Invertida: a Blindagem da Constituição Financeira e a Agonia da Constituição Econômica. Boletim de Ciências Económicas, Coimbra: Ed. Coimbra, p. 57-77, 2006. BERTASSI, André Luís; CILLO, André Roberto e BENEDICTO, Gideon Carvalho de. Lei de Responsabilidade Fiscal: efeitos nas finanças públicas nas capitais dos estados brasileiros. Curitiba: Juruá, 2012.

BINENBOJM, Gustavo. Da supremacia do interesse público ao dever de proporcionalidade: um novo paradigma para o direito administrativo. In: SARMENTO, Daniel (Org.). Interesses públicos versus interesses privados: desconstruindo o princípio de supremacia do interesse público. Rio de Janeiro: Lumen Juris, 2005.

BOBBIO, Norberto. Teoria da norma jurídica. Tradução: Fernando Pavan Baptista e Ariani Bueno Sudatti. Bauru: Edipro, 2001.

BOBBIO, Norberto. Teoria do Ordenamento Jurídico, $6^{\mathrm{a}}$ ed. Brasília: Editora Universidade de Brasília, 1995.

BOBBIO, Norberto. Estado, governo e sociedade: para uma teoria geral da 
política. São Paulo: Paz e Terra, 1987.

BONAVIDES, Paulo; LIMA, Francisco Gérson Marques de; e BEDÊ, Fayga Silveira. Constituição e Democracia - Estudos em Homenagem ao Professor J. J. Gomes Canotilho. São Paulo: Malheiros, 2006.

BORGES, José Souto Maior. Introdução ao direito financeiro. 2. ed. São Paulo: Max Limonad, 1998.

CABRAL, Nazaré da Costa. A Teoria do Federalismo Fiscal, $3^{\text {a }}$ edição. Coimbra: Almedina, 2018.

CAETANO, Marcello. Princípios Fundamentais do Direito Administrativo. Coimbra: Almedina, 2003.

CAMPOS, Carlos Alexandre de Azevedo; OLIVEIRA, Gustavo da Gama Vital de; e MACEDO, Marco Antônio Ferreira (Coordenadores). Direitos Fundamentais e Estado Fiscal: estudos em homenagem ao Professor Ricardo Lobo Torres. Salvador: JusPodivm, 2019.

CANARIS, Claus-Wilhelm. Pensamento Sistemático e Conceito de Sistema na Ciência do Direito, $3^{\text {a }}$ edição. Tradutor: A. Menezes Cordeiro. Lisboa: Fundação Calouste Gulbenkian, 2002.

CANOTILHO, J. J. Gomes; MENDES, Gilmar Ferreira; SARLET, Ingo Wolfgang; STRECK, Lenio Luiz (Coord.). Comentários à Constituição do Brasil. São Paulo: Saraiva - Almedina, 2014.

CARDOSO, Alessandro Mendes. O dever fundamental de recolher tributos no estado democrático de direito. Porto Alegre: Livraria do Advogado, 2014.

CASTRO, José Nilo de. LRF e controle dos gastos de pessoal. In: Servidor público: estudos em homenagem ao Professor Pedro Paulo de Almeida Dutra. FORTINI Cristiana (Org.). Belo Horizonte: Fórum, 2009.

CAVAlCANTE, Ruszel. Despesa pública e corrupção no Brasil - Brasília: Fundação Astrojildo Pereira, 2012.

CAVAlCANTI, Márcio Novaes. Fundamentos da Lei de Responsabilidade Fiscal. São Paulo: Dialética, 2001.

CHRISTOPOUlOS, Basile. Despesa pública: estrutura, função e controle judicial. Maceió: EDUFAL, 2011.

COMPARATO, Fábio Konder. Ensaio sobre o juízo de constitucionalidade de políticas públicas. Interesse público. Belo Horizonte: Fórum, v. 4, n. 16, p. 49-63, 2002 . 
CONTI, José Maurício. A autonomia financeira do Poder Judiciário. São Paulo: MP editora, 2006.

CONTI, J. Mauricio; SCAFF, Fernando F. (coords.). Orçamentos públicos e direito financeiro. São Paulo: Revista dos Tribunais, 2011.

CONTI, José Maurício (coordenador). Poder Judiciário: orçamento, gestão e políticas públicas. São Paulo: Almedina, 2017.

CONTI, José Maurício. Planejamento estratégico do Poder Judiciário. In: CONTI, José Maurício (Coordenador). Poder Judiciário: orçamento, gestão e políticas públicas. São Paulo: Almedina, 2017.

CONTI, José Maurício. Orçamento, Planejamento e Gestão: Desafios e Perspectivas. In: Direitos Fundamentais e Estado Fiscal: estudos em homenagem ao Professor Ricardo Lobo Torres. CAMPOS, Carlos Alexandre de Azevedo; OLIVEIRA, Gustavo da Gama Vital de; e MACEDO, Marco Antonio Ferreira (Coordenadores). Salvador: JusPodivm, 2019.

CONTI, José Maurício. O Plano Mais Brasil e o pacote de mudanças no Direito Financeiro. In: Jota.info - Jota Coluna Fiscal. [Online] 28 de Novembro de 2019. Disponível em: https://www.jota.info/paywall?redirect_to=//www.jota.info/opiniao-eanalise/colunas/coluna-fiscal/o-plano-mais-brasil-e-o-pacote-de-mudancas-no-direitofinanceiro-28112019. Acessado em: 13 de janeiro de 2020.

COUTO E SILVA, Almiro do. Conceitos fundamentais do direito no Estado Constitucional. São Paulo: Malheiros, 2015.

CORREIA, José Manuel Sérvulo. Legalidade e autonomia contratual nos contratos administrativos. Coimbra: Almedina, 2003.

DALLARI, Adilson Abreu. Orçamento impositivo. In: CONTI, José Maurício; SCAFF, Fernando Facury (Org.). Orçamentos públicos e direito financeiro. São Paulo: Revista dos Tribu-nais, 2011. p. 309-327.

DELGADO, Mauricio Godinho. Curso de direito do trabalho. $17^{\mathrm{a}}$ edição. São Paulo: LTr, 2018.

DERZI, Misabel Abreu Machado. Da inconstitucionalidade das sanções institucionais impostas pela Lei de Responsabilidade Fiscal. In: NASCIMENTO, Carlos Valder do (Coordenador). Lei de Responsabilidade Fiscal: teoria e prática. Rio de Janeiro: América Jurídica, 2002.

DI PIETRO, Maria Sílvia Zanella. Discricionariedade Administrativa na Constituição de 1988, $2^{\text {a }}$ edição. São Paulo: Atlas, 2001. 
DI PIETRO, Maria Sylvia Zanella. O Princípio da Supremacia do Interesse Público - sobrevivência diante dos ideais do neoliberalismo. In: Direito Administrativo e Interesse Público: estudos em homenagem ao Professor Celso Antônio Bandeira de Mello. BACELLAR FILHO, Romeu Felipe; e HACHEM, Daniel Wunder (Coordenadores). Belo Horizonte: Fórum, 2010.

DOMInGUES, José Marcos (Org.). Direito Financeiro e Políticas Públicas. Rio de Janeiro: LMJ Mundo Jurídico, 2015.

DROMI, Roberto. Sistema Jurídico e Valores Administrativos. Porto Alegre: Sérgio Antonio Fabris Editor, 2007.

DUGUIT, Léon. Fundamentos do Direito. Tradução de: Eduardo Salgueiro. Porto Alegre: Sergio Antonio Fabris Editor, 2005.

ESTORNINHO, Maria João. A Fuga para o Direito Privado - Contributo para o estudo da actividade de direito privado da Administração Pública. Coimbra: Almedina, 1999.

FEDERIGHI, Wanderley José. Notas sobre fiscalização financeira e orçamentária e o Poder Judiciário: controle interno, controle externo, controle social e a atuação do Conselho Nacional de Justiça. In: CONTI, José Maurício (Coordenador). Poder Judiciário: orçamento, gestão e políticas públicas. São Paulo: Almedina, 2017.

FERNANDES, Andressa Guimarães Torquato. Da possibilidade de controle de constitucionalidade das leis orçamentárias pelo STF com a finalidade de dar cumprimento ao artigo 20 da LRF. In: CONTI, José Maurício (coordenador). Poder Judiciário - Orçamento, Gestão e Políticas Públicas. São Paulo: Almedina, 2017.

FERNÁNDEZ, Tomás-Ramón. Panorama del Derecho Administrativo al comienzo de su Tercera Centuria. Buenos Aires: La Ley, 2002.

FERRAZ, Luciano. Lei de Responsabilidade Fiscal e Medidas para a Redução das Despesas de Pessoal: Perspectiva de Respeito aos Direitos dos Funcionários Públicos Estáveis. In: Aspectos Relevantes da Lei de Responsabilidade Fiscal; Coord.: ROCHA, Valdir de Oliveira. São Paulo: Dialética, 2001.

FERRAZ, Luciano, GODÓI, Marciano Seabra de e SPAGNOL, Werther Botelho. Curso de direito financeiro e tributário, $2^{\mathrm{a}}$ edição. Belo Horizonte: Fórum, 2017. FERRAZ JÚNIOR, Tércio Sampaio. Direito, retórica e comunicação. São Paulo: Saraiva, 1997.

FERRAZ JÚNIOR, Tércio Sampaio. Teoria da norma jurídica, 4a edição. Rio de Janeiro: Forense, 2002. 
FERREIRA, Luiz Tarcísio Teixeira. Parcerias Público-Privadas - Aspectos Constitucionais. Belo Horizonte: Fórum, 2006.

FERREIRO LAPATZA, José Juan. Curso de derecho financiero español. $25^{\mathrm{a}}$ ed. Madrid: Marcial Pons, 2006.

FIGUEIREDO, Carlos Maurício; NÓBREGA, Marcos. Lei de Responsabilidade Fiscal: aspectos polêmicos. Belo Horizonte: Fórum, 2006.

FONROUGE, Carlos M. Giuliani. Derecho Financiero, Volumen I, 4 edición. Atualizada por: NAVARRINE, Suzana Camila y ASOREY, Rubén Oscar. Buenos Aires: De Palma, 1990.

FORTINI, Cristiana (Organizadora). Servidor público: estudos em homenagem ao Professor Pedro Paulo de Almeida Dutra. Belo Horizonte: Fórum, 2009.

FORTINI, Cristina. A Terceirização e a Lei de Responsabilidade Fiscal. In: AGUIRRE DE CASTRO, Rodrigo Pironti (Coordenador). Lei de Responsabilidade Fiscal: ensaios em comemoração aos 10 anos da Lei Complementar $n^{0}$ 101/00. Belo Horizonte: Fórum, 2010.

FREITAS, Juarez. Discricionariedade Administrativa e o Direito Fundamental à Boa Administração Pública. São Paulo: Malheiros, 2007.

GABARDO, Emerson; e HACHEM, Daniel Wunder. O suposto caráter autoritário da supremacia do interesse público e das origens do Direito Administrativo. In: Direito Administrativo e Interesse Público: estudos em homenagem ao Professor Celso Antônio Bandeira de Mello. BACELLAR FILHO, Romeu Felipe; e HACHEM, Daniel Wunder (Coordenadores). Belo Horizonte: Fórum, 2010.

GARCÍA DE ENTERRÍA, Eduardo e FERNÁNDEZ, Tomás-Rámon. Curso de Derecho Administrativo, Tomo I. Madrid: Thomson/Civitas, 2005.

GOMES, Emerson Cesar da Silva. O Direito dos Gastos Públicos no Brasil. São Paulo: Almedina, 2015.

GOMES, Emerson Cesar da Silva. Responsabilidade financeira: uma teoria sobre a responsabilidade no âmbito dos tribunais de contas. Porto Alegre: Núria Fabris, 2012. GUERRA, Evandro Martins. Controle externo da Administração Pública, $4^{\mathrm{a}}$ edição. Belo Horizonte: Fórum, 2019.

HABER, Michel; CHRISTOPOUlOS, Basile Georges Campos e TORRES, Ricardo Ezequiel. Despesa Pública. In: OLIVEIRA, Régis Fernandes de (Coordenador Geral); Coordendores: HORVATH, Estevão; CONTI, José Maurício; SCAFF, Fernando 
Facury. Lições de Direito Administrativo. São Paulo: Revista dos Tribunais, 2016.

HENRIQUES, Elcio Fiori. Os benefícios fiscais no Direito Financeiro e Orçamentário. São Paulo: Quartier Latin, 2010.

HOLMES, Stephen; SUNSTEIN, Cass R. The cost of rights: why liberty depends on taxes. New York: W. W. Norton, 1999.

HORTA, Raul Machado. Problemas do federalismo brasileiro. Revista Forense, Rio de Janeiro: Forense, v. 100, p. 381-402, 2006.

HORVATH, Estevão. Orçamento Público e Planejamento. In: MELLO, Celso Antônio Bandeira de. (Org.). Estudos em homenagem a Geraldo Ataliba. São Paulo: Malheiros Editores, 1997.

JACOBY FERNANDES, Jorge Ulisses. 10 anos de Lei de Responsabilidade Fiscal: a Interpretação dos Tribunais. In: AGUIRRE DE CASTRO, Rodrigo Pironti (Coordenador). Lei de Responsabilidade Fiscal: ensaios em comemoração aos 10 anos da Lei Complementar nº 101/00. Belo Horizonte: Fórum, 2010.

JACOBY FERNANDES, Jorge Ulisses. Tribunais de Contas do Brasil, $4^{a}$ edição. Belo Horizonte: Fórum, 2016.

KANAYAMA, Rodrigo Luís. Orçamento Público: Execução da despesa pública, transparência e responsabilidade físcal. Coleção Temas Polêmicos do Ordenamento Jurídico Brasileiro; Coordenação: Luiz Henrique Sormani Barbugiani, $1^{a}$ edição. Rio de Janeiro: Lumen Juris, 2016.

KANT, Immanuel. Fundamentação da metafísica dos costumes. Tradutor: QUINTELA, Paulo. Lisboa: Edições 70, 1997.

KELSEN, Hans. Teoria Geral das Normas. Porto Alegre: Sérgio Antônio Fabris Editor, 1986.

KELSEN, Hans. O Problema da Justiça. São Paulo: Martins Fontes, 1996.

LARENZ, Karl. Metodologia da Ciência do Direito, $3^{\text {a }}$ edição. Tradução de José Lamego. Lisboa: Fundação Calouste Gulbenkian, 1997.

LEAL, Gabriel Prado. Exceção econômica e governo de crise nas democracias. In: NABAIS, José Casalta e SILVA, Suzana Tavares da (Coordenadores). Sustentabilidade Fiscal em tempos de crise. Coimbra: Almedina, 2011.

LEITE, Cristiane Kerches da Silva. TD 1593 - Federalismo, processo decisório e ordenamento fiscal: a criação da Lei de Responsabilidade Fiscal. Instituto de Pesquisa Econômica Aplicada - IPEA. [Online] Março de 2011. 
http://www.ipea.gov.br/portal/images/stories/PDFs/TDs/td_1593.pdf.

LEITE, Cristiane Kerches da Silva. O processo de ordenamento fiscal no Brasil na década de 1990 e a Lei de Responsabilidade Fiscal (Tese de doutorado). São Paulo: USP, 2005.

LEITE, Harisson. Manual de Direito Financeiro, $8^{a}$ edição. Salvador: JusPODIVM, 2019.

LEWANDOWSKI, Enrique Ricardo. Pressupostos materiais e formais da intervenção federal no Brasil. São Paulo: Revista dos Tribunais, 1994.

LINO, Pedro. Comentários à Lei de Responsabilidade Fiscal - Lei Complementar $n^{\circ}$ 101/2000. São Paulo: Atlas, 2001.

MAYER, Otto. Derecho Adiministrativo Alemán, Tomo I. Buenos Aires: Ediciones Depalma, 2a edición, 1982.

MARQUES NETO, Floriano de Azevedo e FREITAS, Rafael Véras de. Comentários à Lei no 13.655/2018 (Lei de Segurança para a Inovação Pública). Belo Horizonte: Fórum, 2019.

MARTINS, Ives Gandra da Silva. A Lei de Responsabilidade Fiscal e o Federalismo. In: NASCIMENTO, Carlos Valder do (Coordenador). Lei de Responsabilidade Fiscal: teoria e prática. Rio de Janeiro: América Jurídica, 2002.

MARTINS, Ives Gandra da Silva; MENDES, Gilmar Ferreira; NASCIMENTO, Carlos Valder do (Coordenadores). Tratado de Direito Financeiro, Vols. 1 e 2. São Paulo: Saraiva, 2013.

MARTINS, Ives Gandra; e NASCIMENTO, Carlos Valder do (organizadores). Comentários à Lei de Responsabilidade Fiscal, $7^{\mathrm{a}}$ edição (edição eletrônica). São Paulos: Saraiva, 2014.

MARTINS, Maria d'Oliveira. A despesa pública justa: uma análise jurídicoconstitucional do tema da justiça na despesa pública (teses de doutoramento). Coimbra: Almedina, 2016.

MARTINS, Andrea Siqueira. Normas de Direito Financeiro. In: Direitos Fundamentais e Estado Fiscal: estudo em homenagem ao Professor Ricardo Lobo Torres. CAMPOS, Carlos Alexandre de Azevedo; OLIVEIRA, Gustavo da Gama Vital; e MACEDO, Marco Antonio Ferreira (Coordenadores). Salvador: JusPodivm, 2019.

MARZUOLI, Carlo. Principio di legalità e attività di diritto privato della Pubblica Amministrazione. Milano: Giuffrè, 1982. 
MAURER, Hartmut. 2006. Direito Administrativo Geral. Tradução: HECKR, Luís Afonso. Barueri-SP: Manole, 2006.

MELIÁN, José Luis Gil. Intereses generales e interés público desde la perspectiva del Derecho Público español. In: Direito Administrativo e Interesse Público: estudos em homenagem ao Professor Celso Antônio Bandeira de Mello. BACELLAR FILHO, Romeu Felipe; e HACHEM, Daniel Wunder (Coordenadores). Belo Horizonte: Fórum, 2010 .

MENDES, Gilmar Ferreira. Comentários ao artigo 48. In: Comentários à Lei de Responsabilidade Fiscal, $7^{a}$ edição (edição eletrônica). MARTINS, Ives Gandra; e NASCIMENTO, Carlos Valder do (organizadores). São Paulo: Saraiva, 2014.

MOREIRA NETO, Diogo de Figueiredo. Considerações sobre a Lei de Responsabilidade Fiscal. Rio de Janeiro: Renovar, 2001.

MOTTA, Fabrício. Função normativa da Administração Pública. Belo Horizonte: Fórum, 2007.

MOTTA, Fabrício. Publicidade e Transparência nos 10 anos da Lei de Responsabilidade Fiscal. In: AGUIRRE DE CASTRO, Rodrigo Pironti. Lei de Responsabilidade Fiscal: ensaios em comemoração aos 10 anos da Lei Complementar no 101/00. Belo Horizonte: Fórum, 2010.

MOTTA, Paulo Roberto Ferreira. Direito Administrativo - Direito da Supremacia do Interesse Público. In: Direito Administrativo e Interesse Público: estudos em homenagem ao Professor Celso Antônio Bandeira de Mello. BACELLAR FILHO, Romeu Felipe; e HACHEM, Daniel Wunder (Coordenadores). Belo Horizonte: Fórum, 2010 .

MOURA, Frederico Seabra de. Lei Complementar Tributária. São Paulo: Quartier Latin, 2009.

MURPHY, Liam; NAGEL, Thomas. The myth of ownership: Taxes and Justice. New York: Oxford University Press. 2002.

NABAIS, José Casalta e SILVA, Suzana Tavares da (Coordenadores). Sustentabilidade Fiscal em tempos de crise. Coimbra: Almedina, 2011.

NASCIMENTO, Carlos Valder do (Coordenador). Lei de Responsabilidade Fiscal: teoria e prática. Rio de Janeiro: América Jurídica, 2002.

NUNES, Selene Peres; MARCELINO, Gileno Fernandez e SILVA, César Augusto Tibúrcio. Os Tribunais de Contas na interpretação da Lei de Responsabilidade 
Fiscal. DOI: http://dx.doi.org/10.11606/issn.1982-6486.rco.2019.145151 [Artigo]// Revista de Contabilidade e Organizações. - São Paulo : FEA-RP/USP, 2019. - Vol. 13. OLIVEIRA, Régis Fernandes (coordenador geral). Coordenadores: HORVATH, Estevão; CONTI, José Maurício; SCAFF, Fernando Facury. Lições de Direito Financeiro. São Paulo: Editora Revista dos Tribunais, 2016.

OLIVEIRA, Régis Fernandes de. Curso de Direito Financeiro, $8^{\text {a }}$ edição. São Paulo: Malheiros, 2019.

OLIVEIRA, Régis Fernandes de. Regime constitucional do direito financeiro. In: TORRES, Heleno Taveira (Coord.). Tratado de direito constitucional tributário: estudos em homenagem a Paulo de Barros Carvalho. São Paulo: Saraiva, 2005. p. 467- 496.

OLIVEIRA, Régis Fernandes de. Responsabilidade fiscal. 2. ed. São Paulo: Revista dos Tribunais, 2002.

OLIVEIRA, Régis Fernandes. 15 anos da Lei de Responsabilidade Fiscal - desafios e perspectivas (ADI 2.238). In: ABRAHAM, Marcus; GOMES, Marcus Lívio; TORRES, Heleno Taveira (Coord.). Direito financeiro na jurisprudência do Supremo Tribunal Federal: homenagem ao Ministro Marco Aurélio. Curitiba: Juruá, 2016, p. $381-401$.

OLIVEIRA, Weder de. Curso de Responsabilidade Fiscal: direito, orçamento e finanças públicas, $2^{\mathrm{a}}$ edição. Belo Horizonte: Fórum, 2015.

OTERO, Paulo. Legalidade e Administração Pública - O Sentido da Vinculação Administrativa à Juridicidade. Coimbra: Almedina, 2007.

PASCUAL GARCÍA, José; RODRÍGUEZ CASTAÑO, Antonio Ramón. Régimen Jurídico del Gasto Público: Presupuestación, ejecución y control, $7^{\mathrm{a}}$ edición. Madrid: Boletín Oficial del Estado, 2018.

PETIAN, Angélica. Regime Jurídico dos Processos Administrativos Ampliativos e Restritivos de Direito. São Paulo: Malheiros, 2011.

RIGOLIN, Ivan Barbosa. "Serviço terceirizado"não é, nunca foi nem jamais será despesa de pessoal - o insólito e absurdo $\$ 1 \S$, do art. 18, da Lei de Responsabilidade Fiscal. In: NASCIMENTO, Carlos Valder do (Coordenador). Lei de Responsabilidade Fiscal: teoria e prática. Rio de Janeiro: América Jurídica, 2002. RIGOLIN, Ivan Barbosa. Despesa total com pessoal. O art. 18 da Lei de Responsabilidade Fiscal. In: NASCIMENTO, Carlos Valder do (Coordenador). Lei de Responsabilidade Fiscal: teoria e prática. Rio de Janeiro: América Jurídica, 2002. 
RIGOLIN, Ivan Barbosa. Lei de Responsabilidade Fiscal e Despesas com Pessoal. In: NASCIMENTO, Carlos Valder (Coordenador). Lei de Responsabilidade Fiscal: teoria e prática. Rio de Janeiro: América Jurídica, 2002.

RAMOS, Luciano Silva Costa; RINGENBERG, Diogo. Nuances da aplicação da Lei de Responsabilidade Fiscal pelos Tribunais de Contas. In: Revista de Interesse Público, ano 18, nº 95, jan./fev. 2016. Belo Horizonte: Editora Fórum, 2016.

RAWLS, John. Uma Teoria da Justiça. Tradução: Almiro Pisetta e Lenita M. R. Esteves. São Paulo: Martins Fontes, 1997.

REIS, Heraldo da Costa e MACHADO JÚNIOR, José Teixeira. A Lei 4.320 comentada e a Lei de Responsabilidade Fiscal, $36^{\text {a }}$ edição. Rio de Janeiro: IBAM, 2019.

REZENDE, Fernando. A Política e a Economia da Despesa Pública. Rio de Janeiro: Editora FGV, 2015.

REZENDE, Fernando. Em busca do tempo perdido: é preciso buscar o fio da meada para desembaraçar o novelo fiscal. Rio de Janeiro: FGV Editora, 2016.

RIVERO, Jean e MOUTOUH, Hugues. Liberdades Públicas. São Paulo: Martins Fontes, 2006.

ROCHA, C. A. A. A Despesa Total com Pessoal na Ótica da STN e dos Tribunais de Contas Estaduais e Municipais. In: Boletim Legislativo nº 71. Brasília: Núcleo de Estudos e Pesquisas/CONLEG/Senado, 2018.

ROCHA, Joaquim Freitas da. Direito da Despesa Pública. Coimbra: Almedina, 2019.

ROCHA, Silvio Luís Ferreira da. Manual de direito administrativo. São Paulo: Malheiros Editores, 2013.

ROCHA, Valdir de Oliveira (Coordenador). Aspectos Relevantes da Lei de Responsabilidade Fiscal. São Paulo: Dialética, 2001.

RODRÍGUEZ-ARAÑA, Jaime Muñoz. El interés general como categoría central de la actuación de las administraciones públicas. In: Direito Administrativo e Interesse Público: estudos em homenagem ao Professor Celso Antônio Bandeira de Mello. BACELLAR FILHO, Romeu Felipe; HACHEM, Daniel Wunder (Coordenadores). Belo Horizonte: Fórum, 2010.

ROSEN, Harvey S. e GAYER, Ted. Finanças Públicas. Tradução: Rodrigo Dubal; revisão técnica: Stefano Florissi, 10a edição. Porto Alegre: AMGH, 2015.

ROSILHO, André. Tribunal de Contas da União: competência, jurisdição e 
instrumentos de controle. - São Paulo : Quartier Latin, 2019.

SAFATLE, Cláudia; BORGES, João e OLIVEIRA, Ribamar. Anatomia de um Desastre: Os bastidores da crise econômica que mergulhou o país na pior recessão da história (formato: e-book). São Paulo: Portfólio, 2016.

SANTOS, Marta Costa. Novos paradigmas no controlo do sistema fiscal. In: NABAIS, José Casalta; SILVA, Suzana Tavares da (Coordenadores). Sustentabilidade Fiscal em tempos de crise. Coimbra: Almedina, 2011.

SCAFF, Fernando F.; CONTI, J. Mauricio. Lei de Responsabilidade Fiscal. 10 anos de vigência - questões atuais. Florianópolis: Conceito Editorial, 2010.

SCAFF, Fernando Facury (Coord.). Direito Tributário e Financeiro aplicado. São Paulo: Quartier Latin, 2010.

SCAFF, Fernando Facury. Normas gerais de direito financeiro. In: MARTINS, Ives Gandra da Silva; MENDES, Gilmar Ferreira; NASCIMENTO, Carlos Valder do (Coord.). Tratado de direito financeiro. São Paulo: Saraiva, 2013. p. 30-44.

SCHERZBERG, Arno. Para onde e de que forma vai o Direito Público? Tradução: Kelly Suzane Alflen da Silva. Porto Alegre: Sergio Antonio Fabris Editor, 2006.

SCHIER, Adriana da Costa Ricardo, O Princípio da Supremacia do Interesse Público sobre o Privado e o direito de greve dos servidores públicos. Direito Administrativo e Interesse Público: estudos em homenagem ao Professor Celso Antônio Bandeira de Mello. BACELLAR FILHO Romeu Felipe e HACHEM Daniel Wunder (Coordenadores). Belo Horizonte: Fórum, 2010.

SECRETARIA DO TESOURO NACIONAL. Relatório: Boletim de Finanças dos Entes Subnacionais. Brasília/DF, 2019.

SERRA, José. Relatório e Anteprojeto da Comissão do Sistema Tributário, Orçamento e Finanças da Assembléia Nacional Constituinte. Brasília: Centro Gráfico do Senado Federal, 1987.

SILVA, Suzana Tavares da. Sustentabilidade e solidariedade em tempos de crise. In: NABAIS, José Casalta; SILVA, Suzana Tavares da (Coordenadores). Sustentabilidade Fiscal em tempos de crise. Coimbra: Almedina, 2011.

SIQUEIRA, Marcelo Rodrigues. Os desafios do Estado Fiscal contemporâneo. In: NABAIS, José Casalta; SILVA, Suzana Tavares (Coordenador). Sustentabilidade Fiscal em tempos de crise. Coimbra: Almedina, 2011.

SUNDFELD, Carlos Ari. Direito Administrativo Ordenador. São Paulo: Malheiros, 2003. 
SUNDFELD, Carlos Ari. Fundamentos de Direito Público. $5^{\text {a }}$ edição, $7^{\text {a }}$ tiragem. São Paulo: Malheiros, 2017.

TORRES, Heleno Taveira. Direito Constitucional Financeiro: teoria da constituição financeira. São Paulo: Revista dos Tribunais, 2014.

TORRES, Ricardo Lobo. Curso de Direito Financeiro e Tributário. $20^{\mathrm{a}}$ edição. Rio de Janeiro: Renovar, 2018.

TORRES, Ricardo Lobo. Tratado de direito constitucional financeiro e tributário.

Vol. I - Constituição financeira, sistema tributário e estado fiscal. Rio de Janeiro: Renovar, 2009.

TORRES, Ricardo. Tratado de direito constitucional financeiro e tributário. $3^{\mathrm{a}}$ edição. Vol. V: o orçamento na Constituição. Rio de Janeiro: Renovar, 2008.

TORRES, Ricardo Lobo. A ideia de liberdade no Estado Patrimonial e no Estado Fiscal. Rio de Janeiro: Renovar, 1991.

VILANOVA, Lourival. Estruturas Lógicas e o Sistema de Direito Positivo. São Paulo: Noeses, 2005.

VILANOVA, Lourival. Causalidade e Relação no Direito, $4^{\text {a }}$ edição. São Paulo: Editora Revista dos Tribunais, 2000.

ZANOBINI, Guido. Autonomia pubblica e privata. In: Scritti vari di Diritto Pubblico. Milano: Giuffrè, 1950. 